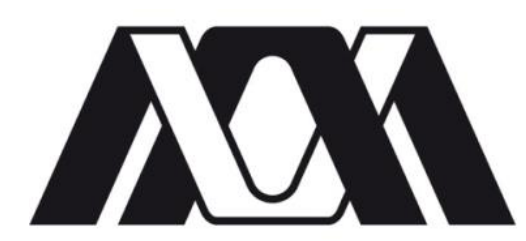

UNIVERSIDAD AUTÓNOMA METROPOLITANA

UNIDAD IZTAPALAPA

DIVISIÓN DE CIENCIAS SOCIALES Y HUMANIDADES

\title{
HACIA UNA COMPRENSIÓN Y CONSOLIDACIÓN DE LA PIEZA COMO GÉNERO TEATRAL MODERNO
}

TESIS PARA OBTENER EL GRADO DE MAESTRO EN HUMANIDADES

LÍNEA ACADÉMICA EN TEORÍA LITERARIA

PRESENTA:

ANDRÉS RICARDO CASTRO HURTADO

ASESOR:

DR. JESÚS EDUARDO GARCÍA CASTILLO

LECTORES:

MTRA. ADRIANA MARÍA HERNÁNDEZ SANDOVAL MTRA. GUILLERMINA FUENTES IBARRA

Ciudad de México, Diciembre de 2012 
Especial agradecimiento a la Universidad Autónoma Metropolitana; al posgrado en Humanidades, línea de Teoría Literaria, sus docentes y su planta administrativa; al asesor y a las lectores de esta investigación doctor Jesús Eduardo García, Maestra Adriana María Hernández Sandoval y Maestra Guillermina Fuentes Ibarra; a la cartelera teatral mexicana; a Socorro González Ocampo, a Louise David, a los compañeros de maestría; y a los maestro del Centro de Capacitación Cinematográfica de México, Gilberto Guerrero, Ximena Escalante y Flavio González Mello. 


\section{INDICE}

$\begin{array}{ll}\text { INTRODUCCIÓN } & 4\end{array}$

CAPÍTULO I LA INCURSIÓN DE UN GÉNERO 9

1.1 Origen de la discusión 9

1.2 Acercamientos a la teoría dramática y sus cuestiones contemporáneas 11

1.3 Acercamientos a la especificidad del "Género" 18

1.4 Raíces humanas, sociales y estéticas de la pieza 25

CAPÍTULO II ELEMENTOS ESTRUCTURALES DE LA PIEZA: DIVERGENCIAS Y ENCUENTROS 56

2.1 Concepción: tema, anécdota y estructura $\quad 59$

2.2 Relación con la realidad: enfoque, material, tono 68

2.3 Catarsis: la obra y su relación con el público 79

2.4 Personaje: La vida cotidiana y trayectoria (o dinámica) del personaje 84

CAPÍTULO III LA PIEZA COMO ESTÉTICA DE LA DINÁMICA DEL PODER EN LA VIDA $\begin{array}{ll}\text { COTIDIANA } & 96\end{array}$

$\begin{array}{ll}\text { CONCLUSIONES } & 141\end{array}$

$\begin{array}{ll}\text { BIBLIOGRAFÍA } & 153\end{array}$ 


\section{INTRODUCCIÓN}

Al escuchar por primera vez el género que era denominado pieza me llamó la atención la manera cómo se planteaba como un conjunto de obras dramáticas que ponían el ojo en la médula de la vida cotidiana. Para un subcontinente asumido melodramático en exceso como lo demuestran desde Argentina hasta México lo tangos, boleros o rancheras, y las telenovelas, la pieza se presentaba como un género de emociones contenidas, de trayectorias internas más que externas y de personajes construidos con base en un nuevo arquetipo: el hombre común. Ya había entendido que la tragedia en su concepción tradicional me era ajena y la perennidad de la comedia la hace presente en todas las esferas de la existencia. Sin embargo, la pieza era algo nuevo que tenía que ver más con el sujeto y sus circunstancias que con la exposición de valores, la exaltación de los sentimientos, el castigo de vicios o la caída de hombres de estaturas divinas, patricias o monárquicas. Con estas cuestiones, decidí preguntarme sobre su existencia, los fenómenos que la generaron, su composición poética y las posibles cuestiones que de allí se pueden desprender. La presente investigación procura ampliar la discusión sobre la comprensión y la consolidación del género de la pieza, enmarcada dentro la teoría de los siete géneros, propuesta de Luisa Josefina Hernández que ha sido un método protagónico en las escuelas de enseñanza teatrales y literarias de México. Sin embargo, su configuración, como se espera demostrar, se ha dado más en el terreno práctico que teórico, por lo tanto, con la 
intención de dar con una mirada más académica del género se pretende robustecer el significado de su concepto en la circulación natural que ya le es propio.

El manejo del término pieza, en México, es amplio y se propulsó a partir de su aparición en la primera mitad del siglo XX. Sin embargo, la intuición inicial que nos hacía asociar el contexto social con el surgimiento de la pieza llevó a preguntarnos sobre la especificidad de los estudios teatrales y de la teoría de géneros dada la inscripción de la pieza en la teoría de los siete géneros dentro del compendio general de la teoría dramática. En primera instancia, se trata de comprender qué significa, como método, la teoría dramática para así señalar la relación que aguarda con el contexto ideológico, y de esta manera establecer la postura que tomamos sobre la teoría de géneros. Como se comprenderá, la teoría de géneros se nos hace de suma importancia como herramienta de análisis, no con el propósito de encajonar a la fuerza cualquier obra en cualquier género, sino para aguzar la mirada y generar un acercamiento que permita dar luz sobre las cuestiones que aduce una obra en general. Pretendemos así, ver en la teoría de los siete géneros la estrecha relación que guarda con el sistema ideológico imperante y con el campo literario existente, tanto en la determinación de las obras que abarca como en la manera en que define sus elementos estructurales.

¿Tiene relación la pieza con el tiempo en que surgió? Evidentemente respondemos que sí. Con esta hipótesis, se procura hacer una amplia revisión de las raíces humanas, sociales y estéticas que dieron surgimiento al género. Adscritos en la idea de que cada tiempo genera sus propias formas de expresión, una mirada amplia e histórica se hace necesaria para comprender, no sólo qué estaba sucediendo en los albores del surgimiento del géneros (finales del siglo XVIII), sino las implicaciones que tales movimientos tuvieron en la configuración del género. Advertimos que inicialmente se hace un recorrido histórico lineal, pero gracias al estudio de las raíces de la pieza así como de sus elementos estructurales surgió otra hipótesis que se desarrolla 
a través de procesos históricos no lineales dados en las dinámicas del poder y su especial injerencia en la vida cotidiana. Si para explicar un género se hace imperante un análisis del personaje y su contexto, puesto que sin uno no hay el otro, era necesario entender cómo opera, en la pieza, la rivalidad y el desequilibrio en la psique individual de los personajes. Tratamos así de complementar la propuesta de Humberto Lizárraga, quién expone con claridad las dinámicas de la frustración de manera sicoanalítica, con componentes sociales propios de la manera cómo se ejerce el poder a partir del siglo XVIII.

En la segunda parte de esta investigación, el interesado encontrará la discusión referente a los elementos estructurales que son propio de la teoría de los siete géneros y que configuran a la pieza. Para esto, se procedió a recoger la literatura sobre los elementos estructurales que le dan forma, con el fin de señalar los puntos en común y las divergencias en las terminologías y las nociones que se usan, especialmente en el campo práctico, para determinar los componentes del género pieza. Así como hay unánime claridad en algunos términos, también hay confusiones propias de cualquier teoría de géneros. Nuestra aspiración es dar claridad sobre esta situación con el fin de ampliar la discusión sobre la existencia de la pieza y la configuración que le da forma. De los autores revisados, concluimos que la teoría de los siete géneros le otorga una cualidad específica a cada obra según cuatro grandes criterios que tienen, a su vez, otras subcategorías: concepción, relación con la realidad, catarsis y personaje.

Como se dijo, gracias a la inmersión en las raíces estéticas, sociales y humanas de la pieza, y de la revisión de la literatura sobre los elementos estructurales de la pieza se encontró que dicho género es un intento de reconstrucción de los esquemas propios de la vida de los personajes, esquemas que creían autónomos y de discreción individual pero que finalmente vienen a estar dados por la manera cómo el poder nos construye como sujetos y construye nuestras realidades, confrontando así la visión que tiene el personaje de su contexto y de si 
mismo. Dicha confrontación es como una bocanada de aíre puro en una realidad asfixiante: el personaje saca la cabeza para hacer una valoración de su vida, sin embargo su realidad será tan agobiante que termina sucumbiendo ante el ahogo. Desde esta perspectiva, ampliamos la elaboración sobre las dinámicas del poder en la vida cotidiana y tenemos como objetivo señalar que la pieza es una estética de esta circunstancia. Como se expondrá con Michel Foucault, las estrategias del poder tendieron a volverse más sutiles a partir del clasicismo, trayendo como efecto una fuerte configuración de las individualidades a través de normas y disciplinas que encauzan la conducta. Si bien esa sería una mirada general, con Erving Goffman nos centramos en dinámicas más propias de la vida cotidiana y las estrategias de presentación que hace de si mismo cada individuo, en las cuales se reflejan las injerencias de dichas disciplinas. Nos interesa hacer confluir la mirada de Foucault y de Goffman, porque estamos convencidos de que una perspectiva macrocontextual y una microcontextual de las dinámicas del poder arroja luces sobre la comprensión de la pieza como género teatral contemporáneo.

Apoyados en las piezas mexicanas, en el sentido genérico de la palabra, Felicidad y Fotografía en la playa de Emilio Carballido, Los frutos caídos de Luisa Josefina Hernández, Señoritas a disgusto de Antonio González Caballero, Con la frente en el polvo de Luis G. Basurto, De pétalos perennes de Luis Zapata, Las bellas imágenes de Pablo Salinas y La puerta de Edgar Ceballos - piezas que van del año 1955 al año 2000- se busca ejemplificar la manera en que las dinámicas de poder en la vida cotidiana generan los conflictos de los personajes. Pero como se verá, dicho conflicto no es con un poder en específico, es con su encarnación tanto en los otros personajes interactuantes con el personaje principal (si lo hay) como también en el interior mismo de éste. Esperamos mostrar cómo el personaje de la pieza es el infierno de los otros y de si mismo gracias a que es el vehículo de un poder ejercido desde el contexto que lo determina. 
La pieza dentro de la teoría dramática, las raíces humanas, sociales y estéticas de la pieza, los elementos estructurales y la pieza como estética de las dinámicas del poder en la vida cotidiana son las columnas vertebrales de este trabajo que tiene como objetivo dar un sustento sobre la existencia de este género a pesar de que algunas voces sean adversas a esta idea. La pieza es una práctica textual con características específicas que Luisa Josefina Hernández pudo observar y que se ha venido practicando de manera espontánea o siguiendo sus parámetros. Su complejidad no es gratuita, por lo que finalmente se aspira a que la revisión de esta investigación aporte en su consolidación dentro del campo teatral teórico y práctico, y en el campo literario académico. 


\section{CAPÍTULO I}

\section{LA INCURSIÓN DE UN GÉNERO}

\subsection{Origen de la discusión}

La fábula del origen de la siguiente investigación comienza con la impresión, en 1940, del libro Itinerario del autor dramático y otros ensayos de Rodolfo Usigli. En él, el autor plantea la posibilidad de nueve formas textuales dramáticas, de nueve géneros dramáticos: la tragedia, la comedia, la tragicomedia, la sátira, la farsa, el melodrama, el sainete, la obra poética y la pieza. A esta última, motivo de nuestro trabajo, la definió de la siguiente manera:

Pieza: Obra seria de extensión normal, comúnmente llamada drama, que aborda la exposición y el conflicto de temas contemporáneos graves, mentales, sentimentales, sociales o biológicos. Sus antecedentes más importantes datan del naturalismo, sobre todo de Ibsen, Strindberg y Bernard Shaw. La pieza es generalmente realista o naturalista, y aunque a menudo incluye la muerte en sus elementos dramáticos, no llega a ser una tragedia por causa de la altura social de sus personaje. ${ }^{1}$

El Itinerario del autor dramático vino a concentrar los estudios de teoría dramática realizados por Usigli a través de cursos, publicaciones y una serie de programas de radio, y, como tal, marca el inicio de dichos estudios en el ámbito académico mexicano:

\footnotetext{
${ }^{1}$ Rodolfo Usigli, Itinerario del autor dramático y otros ensayos, Fondo de Cultura Económica, México, 1940, p. 35.
} 
Para los cincuenta ya existe una generación formada teóricamente bajo la égida de Usigli, y en los sesenta hay otras generaciones surgidas del taller de dramaturgia de Emilio Carballido y de los cursos y seminarios de teoría y composición dramática de Luisa Josefina Hernández, ambos discípulo de Usigli e, incluso, la segunda, continuadora de su cátedra en la Facultad de Filosofía y Letras de la UNAM.

Esta actividad continúa a principios de los años setentas en los talleres de composición dramática de Hugo Arguelles, Vicente Leñero, Antonio González Caballero y Juan Tovar -por citar sólo los más conocidos- y lo mismo ocurre en los años ochentas en los talleres que imparten los discípulos de todos ellos. ${ }^{2}$

Como bien lo plantea Armando Partida Tayzan, el desarrollo de estos estudios en México es amplio, y su fomento, por lo menos en la segunda mitad del siglo XX, fue exponencial.

Se destaca en esta labor Luisa Josefina Hernández, en cuyas clases se configuraron las ideas de Usigli y en donde estableció lo que en el argot teatral se conoce como la teoría de los siete géneros. Al respecto, Claudia Cecilia Alatorre dice:

Esta última [Hernández], dramaturga y con toda seguridad la máxima autoridad en crítica dramática en México. Ha sido también maestra, iniciadora del método y su propagadora más eficaz a muchas generaciones, desde la Facultad de Filosofía y Letras en la carrera de Literatura Dramática y Teatro de la UNAM y la Escuela Nacional de Teatro del INBA.

Luisa Josefina Hernández logra conformar un método de gran precisión, que permite un análisis de las constantes más comunes dentro de cada género y que facilita una visión diacrónica y sincrónica del drama. ${ }^{3}$

Sobre la reputación de dicho método, Juan Tovar especifica: "se enseña en las escuelas, se maneja en los talleres, actores y directores lo utilizan como una lengua franca. Sobre ella se han escrito diversos estudios y publicado media docena de libros -ninguno, por desgracia, de su creadora, Luisa Josefina Hernández, que se ha limitado a exponerla en cátedra". ${ }^{4}$ Dicho método plantea que...

...toda obra tiende a caer dentro de siete formas: tragedia, comedia, pieza, tragicomedia, melodrama, farsa y una a la que Eric Bentley se refiere como "Teatro de compromiso", y a la que L. J. Hernández llama Teatro Didáctico. En cuál de estas formas encaja cierta obra depende de la singular combinación de ciertos elementos dados con ella. Estos elementos, comunes a todo drama, son el personaje, la trayectoria de la figura dramática en la obra, el tono, la

\footnotetext{
${ }^{2}$ Armando Partida Tayzan, Modelos de acción dramática aristotélicos y no aristotélicos, Editorial Itaca, 2004, p. 10.

${ }^{3}$ Claudia Cecilia Alatorre, "Los géneros dramáticos”, en Análisis del drama, 3a. ed., Escenología, México, 1999, pp. 25-26.

${ }^{4}$ Juan Tovar, Doble vista, Editorial El Milagro, México, 2006, p. 57.
} 
concepción y la relación que existe entre el público y la obra. ${ }^{5}$

Como se ve, la visión de Hernández abarca, de sus siete propuestas, los cinco incluidos por Erick Bentley en su paradigmático libro La vida del drama. ${ }^{6}$ Además de los ya citados John Kenneth Knowles y Cecilia Alatorre, sea este el momento para indicar que entre aquellos que han sistematizado, escrito y publicado sobre tal método se encuentran: Virgilio Ariel Rivera en La composición dramática, estructura y cánones de los siete géneros $;{ }^{7}$ Consuelo Garrido con un artículo en Las mujeres y la dramaturgia mexicana del siglo $X X ;^{8}$ y el también citado Juan Tovar con un escrito dedicado al tema en su libro Doble vista. Todos ellos reconocen la herencia de Luisa Josefina Hernández, compañera de estudió de Bentley en Columbia University en los años cincuenta, época en que éste preparaba su obra ya mencionada.

Conviene entonces que, dado que estos autores se centran y concentran en la teoría dramática, expongamos aquí algunos elementos significativos de los que se ocupa dicha teoría, como una manera de ubicar la propuesta de Hernández en tal universo.

\subsection{Acercamientos a la teoría dramática y sus cuestiones contemporáneas}

En términos generales, la desintegración del átomo que funge como principio de la bomba atómica tiene un equivalente de funcionamiento al de la tragedia griega. Albert Einstein hacía la equiparación de la siguiente manera: "un cuerpo que se sale de su órbita, rompe la armonía con

\footnotetext{
${ }^{5}$ John Kenneth Knowles, “Introducción”, en Luisa Josefina Hernández: Teoría y práctica del drama, trad. de Antonio Argudín, rev. y pres. de Tomás Espinoza, UNAM, México, 1980, p. 16. Éstas son las nociones de Knowles, pero como se verá, dichas nociones varían según el autor.

${ }^{6}$ Erick Bentley, La vida del drama, Editorial Paidós Estudios, Buenos Aires, 1982.

${ }^{7}$ Virgilio Ariel Rivera, La composición dramática, Editorial Escenología, México, 2004.

${ }^{8}$ Consuelo Garrido, No ser héroes, apuntes en torno a la pieza en algunas clases de teoría dramática de Luisa Josefina Hernández, en Claudia Gidi y Jacqueline Bixler (coords.), Las mujeres y la dramaturgia mexicana del sigo XX, ed. El Milagro, México, 2011.
} 
el infinito, hace sobrevenir el caos y el desorden cósmico se desencadena. Posteriormente, la armonía del universo, que es infinitamente superior, ejerce su fuerza contraria y el orden es reestablecido". 9 Sin embargo, aunque Einstein sólo está haciendo un símil entre el funcionamiento del átomo y el de la tragedia, cabe señalar que la experiencia dramática no existe en una prueba atómica de un laboratorio o en un atolón en el océano y, en cambio, sí se origina en la representación de Edipo Rey o en Muerte de un viajante, puesto que éstas han sido concebidas para que las colisiones de "sus cuerpos salidos de órbita" allí expuestos sean apreciadas por un auditorio. Por tal, los conflictos entre átomos no son dramáticos, mientras que sí lo son los conflictos que puedan existir entre los personajes de una tragedia. Se establece, entonces, que el carácter originariamente ritual del teatro, como acto social, le específica en esencia la implicación dialéctica entre la representación y el público que observa. Sobre este fenómeno, Bentley subraya:

Los hechos no son dramáticos por sí mismos. El drama requiere el ojo del espectador. Ver el aspecto dramático de un acontecimiento significa tanto percibir los elementos en conflicto como reaccionar emocionalmente ante ellos. Esta respuesta emocional consiste en conmoverse, en sentirse embargado de asombro ante el conflicto. Pero ni siquiera el conflicto es dramático por sí mismo. Aun en el caso en que llegáramos a perecer todos en una guerra nuclear, los conflictos subsistirían, por lo menos en el terreno de la física y de la química. No se trataría entonces del drama sino de un proceso. Si el drama es algo que se ve, debe haber alguien que vea. El drama es un hecho humano. ${ }^{10}$

Esto indica, en las mismas palabras de Bentley, que tanto el espectador está en capacidad de "percibir los elementos en conflicto", así como la obra posee las cualidades para provocar "reacciones emocionales ante ellos", "conmover", "embargar de asombro". Sería esto, en principio, el fin último de la obra dramática. ¿Cómo se logra tal efecto? Se sabe que por lo menos desde Aristóteles se ha estado cavilando dicho artificio, y quizá el estagirita sentó las bases que han permitido pensarlo desde la perspectiva de una estructura lógica, lo que implica -

\footnotetext{
${ }^{9}$ Einstein citado por Rivera en op. cit., p. 72.

${ }^{10}$ Bentley, op. cit., p. 16.
} 
sin querer convertir todo resultado producto del cuestionamiento en poéticas, en el sentido preceptivo de la palabra- hacer una inmersión sobre cómo opera el drama de manera genérica; pregunta que de suya cuenta abona el espacio para el desarrollo de una teoría dramática.

En la Poética, según Aristóteles, podemos encontrar ideas alrededor de la tragedia y la epopeya: sus especies, sus partes constitutivas, el número de éstas y sus diferencias, las causas que contribuyen al éxito o fracaso de la obra, las críticas que son posibles y las respuestas que hay que dar a ellas. ${ }^{11}$ Desde entonces, Aristóteles ya enunciaba $-\mathrm{y}$ anunciaba-, entre otras, nociones como fábula, caracteres, unidad de acción, y especificaba que los hechos en la fábula debían mantener un ordenamiento lógico y estructurado para mantener la unidad de acción llevada a cabo por los caracteres. Sin referirse directamente a la noción de estructura, Aristóteles implícitamente plantea la necesidad de ésta para estudiar las propiedades específicas de la forma del drama. Patrice Pavis la define de la siguiente manera: "Estructura indica que las partes constituyentes del sistema se organizan según un orden que produce el sentido de totalidad $[\ldots]$ Las artes poéticas constituyen tratados normativos de composición dramática. Enuncian las reglas y los métodos de construcción de la fábula, del equilibrio de los actos o de la naturaleza de los personajes". ${ }^{12}$

Debemos, entonces, al mismo Aristóteles pensar las obras dramáticas en términos de partes constituyentes de un sistema organizado. Bentley acompaña esta afirmación cuando se pregunta sobre cuál es la materia prima de la trama en una obra de teatro. Inicialmente, la respuesta de Bentley es la vida. Para dicho autor, sin embargo, la respuesta no deja de ser demasiado amplia, por lo que es relevante señalar que "el análisis de los materiales de la trama

\footnotetext{
${ }^{11}$ Aristóteles, Poética, tr. Del griego de Francisco de P. Samaranch, ed. Aguilar, Madrid, 1966, p. 109.

${ }^{12}$ Patrice Pavis, Diccionario del teatro. Dramaturgia, estética, semiología. Editorial Paidós, Barcelona, 1998, s.v. Estructura dramática.
} 
no puede iniciarse mientras no se haya logrado aislar alguna unidad menor que la "vida". ${ }^{13}$

Asumida la importancia de establecer partes que configuren a la obra para poder llevar a cabo un análisis, podemos exponer con Pavis una definición más amplia de lo que sería una teoría del teatro, a la que se refiere como una "disciplina en elaboración que se interesa por los fenómenos teatrales (texto y escena) para explicarlos integrándolos en un conjunto más amplio constituido por un sistema de leyes que rigen la representación". ${ }^{14}$ También señala que tal sistema debe considerar tanto la historicidad como las formas teóricamente posibles: "la teoría es una hipótesis acerca del funcionamiento de la representación particular estudiada. Provisto de esta hipótesis, el investigador se concentrará luego en precisar el modelo y en restringir o ampliar la teoría". ${ }^{15} \mathrm{La}$ definición de Pavis sostiene la idea de que dentro de la obra (y solamente dentro de la obra) están los elementos que permitirían hacer una descripción explicativa del "fenómeno teatral". Y si acaso considera a la historicidad se está refiriendo a un desarrollo de los estudios dramáticos en tanto su pertenencia al universo de los estudios literarios y su evolución para así proponer un modelo que "amplíe” o "restrinja” la teoría.

La visión de Pavis, por sus características estructuralistas, se ubica en una perspectiva inmanente. Visión que comparte parcialmente Maria Serguieivna Kurguinian quien plantea que: “La correlación de los rasgos relativamente invariables, 'eternos' y eventuales, en proceso de transformación, del género dramático y de sus subgéneros, la interacción sintética del drama con otras formas de los subgéneros y los vínculos complejos de los géneros dramáticos entre unos y otros" $" 16$ son, parcialmente, las cuestiones sustanciales de la teoría contemporánea del drama. Pero además, continuando con Kurguinian, la inmersión en estas nociones -planteadas

\footnotetext{
${ }^{13}$ Bentley, op. cit., pp. 15-16.

${ }^{14}$ Pavis, op. cit., s.v. Teoría del teatro.

${ }^{15} \mathrm{Id}$.

${ }^{16}$ Maria Serguieivna Kurguinian, Hacia una teoría dramática. Trad. Armando Partida Tayzan. Toma, ediciones y producciones escénicas y cinematográficas/Gobierno del Estado de Veracruz, Instituto de Cultura del Estado de Durango, México, 2010, p. 20.
} 
(como lo hace Pavis) dentro de su propio desarrollo literario y por sus aspectos formales de las leyes específicamente estructurales- permiten penetrar en el contenido de su esencia para identificar la posibilidad de la sobrevivencia del género de la tragedia en las condiciones de la sociedad capitalista y socialista, por medio de la transformación de dicho género, así como también las bases ideológicas de los problemas de la poética del drama, su afinidad orgánica a las cuestiones contemporáneas más agudas, alrededor de las cuales giran las discusiones de los representantes de dos concepciones del mundo contrapuestas. ${ }^{17}$

Kurguinian escribe esto en Moscú, en 1964, así que en el marco de la Guerra Fría era casi imposible escapar a la polarización establecida en el mundo en ese momento. Sin embargo, es destacable la forma en que la autora concilia dentro de la teoría dramática la dialéctica de los universos que el teatro plantea, la del conflicto exhibido y la de los espectadores que lo aprecian; la del funcionamiento estructural de la obra y su estudio para así adentrarnos en los discurso ideológicos y las “cuestiones contemporáneas” en pugna.

La teoría dramática se asienta, entonces, no sólo en el hecho humano sino en la relación que pueda existir entre el hombre y su sociedad o su mundo actual y la capacidad que tiene el primero de ver a la segunda a través del teatro; así, séase dramaturgo, director o estudioso del teatro, siempre está en juego en el hecho teatral la dialéctica existente en el sistema en que se produce o se representa. Suscribimos así a la propuesta de Kurguinian, quien además plantea que "el drama tiene relación directa con el planteamiento que actualmente se hacen los dramaturgos contemporáneos: ¿se puede reproducir el mundo actual con los recurso del teatro?". ${ }^{18}$

Tal perspectiva recuerda el apuro del personaje de Borges en el cuento La busca de

\footnotetext{
17 Ibid. p. 20.

${ }^{18}$ Kurguinian op. cit., p. 19.
} 
Averroes. Éste, mientras trabajaba en la traducción y los comentarios de la Poética de Aristóteles, se encuentra con dos palabras ineludibles que pululaban en el escrito y que nadie a su alrededor barruntaba lo que querían decir, deviniendo en que, según Borges, "Averroes, encerrado en el ámbito del islam, nunca pudo saber el significado de las voces tragedia y comedia". ${ }^{19}$ En este sentido, Kurguinian coincide con George Steiner cuando éste firma que, a pesar de que "todos los hombres tienen conciencia de la tragedia en la vida", la tragedia, como género dramático, es "privativa de la tradición occidental", "ajena al sentido judaico del mundo", así como de otras culturas, y perteneciente a un mundo al cual no es extraño "representar la angustia privadas en un escenario público". Steiner nos recuerda que "tanto esa noción [la de la tragedia], como la visión del hombre que implica son griegas. Y casi hasta el momento de su decadencia, las formas trágicas son helénicas". ${ }^{20}$ Se puede entrever, entonces, en la premisa de Steiner, junto a la de Kurguinian, una inclinación a enmarcar en un sistema ideológico predominante el concepto de tragedia que estuvo en boga hasta la aparición de la pièce bien faite en el siglo XIX y que aún predomina como estándar cuando se habla del género.

Dicha dialéctica también la podemos ver en la relación que existe entre estructura de la obra y la ideología en la que se delimita. Lo que se quiere subrayar es que la ideología, entendida como "la relación (imaginaria) de los individuos con las relaciones de producción y las relaciones que de ella resultan" y que a su vez representa "la relación imaginaria de esos individuos con las relaciones reales en que viven", ${ }^{21}$ opera como elemento vital que se cierne sobre los análisis dramáticos, que en esencia enmarcan estudios estructurales.

Si recordamos los elementos que presentamos inicialmente con Aristóteles y después con

\footnotetext{
${ }^{19}$ Jorge Luis Borges, La busca de Averroes, en El Aleph, Alianza Editorial, Madrid, 2005, p 117.

${ }^{20}$ George Steiner, Muerte de la tragedia (1961), trad. E. L. Revol, Editorial Monte Ávila, Caracas, 1991, p. 9.

${ }^{21}$ Louis Althusser, Ideología y aparatos ideológicos de estado (1969), trad. De José Sazbón, en Slavoj Zizek (comp.), Ideología. Un mapa de la cuestión, Fondo de cultura Económica, Buenos Aires, 2003, pp. 115-155.
} 
Pavis (citas 11 y 12), como lo son la fábula, los actos y los personajes (o aquellos rasgos que se puedan especificar para llevar a cabo un estudio dramático), nos daremos cuenta de que son elementos que funcionan dentro de los terrenos de la ideología (dado su principio de mutabilidad que le permite “adaptarse a las más diversas pulsiones”, como diría Ángel Rama ${ }^{22}$ ) con lo cual es casi imposible pedir, como lo anticipamos, a un análisis estructural dentro del teatro que sea puramente inmanentista. En aquellos elementos señalados vemos cómo, para analizar la obra dramática, podemos asociar la siguiente postura de Lukács:

...la verdad de la vida sólo puede manifestarse en la praxis, en los actos y en las acciones de los hombres. Las palabras de los hombres y sus pensamientos y sentimientos puramente subjetivos se revelan verdaderos o no, francos o falsos, grandes o limitados, sólo cuando se traducen en la praxis; cuando las acciones y los actos de los hombres se confirman o evidencian ante la prueba de la realidad. Sólo la praxis humana puede expresar concretamente la esencia del hombre. ${ }^{23}$

De la misma manera, Lukács plantea que "Los nuevos estilos, los nuevos modos de representar la realidad jamás surgen de una dialéctica inmanente a las formas artísticas aunque se vinculen siempre a formas y estilos del pasado. Todo nuevo estilo surge, como una necesidad histórico social de la vida y es producto necesario de la evolución social”. ${ }^{24}$

En conclusión, los estudios de teoría dramática conciernen al universo del drama como género literario. Como hecho humano y fenómeno teatral le incumben, según lo planteado por Pavis, las propiedades específicas de la escena y del texto; y tales propiedades consideran ejemplos históricos y formas teóricas posibles para estudiar, como lo propone Kurguinian, la correlación de los rasgos relativamente invariables, eternos y eventuales, en proceso de transformación del género dramático y de sus subgéneros, así como la interacción sintética del drama con otras formas de los subgéneros y los vínculos complejos de los géneros dramáticos

${ }^{22}$ Ángel Rama, Indagación de la ideología de la poesía (los dípticos seriados de Versos Sencillos), en Carlo Altamirano y Beatriz Sarlo, Literatura/Sociedad, Hachette, Buenos Aires, 1983, p. 211.

${ }^{23}$ Georg Lukács, ¿Narrar o describir? (1936), en Carlos Altamirano y Beatriz Sarlo (comps.) Literatura y sociedad, Cetro Editor de América Latina, Buenos Aires, 1977, p. 46.

${ }^{24}$ Ibid., p. 42. 
entre unos y otros. De la misma manera, en el análisis de los elementos estructurales de la obra (elementos que igualmente propone la teoría dramática) se pueden encontrar pistas sobre la evolución del drama, de los géneros y de las obras a través de las condiciones de las ideologías imperantes. Así, la teoría dramática se alza como una hipótesis y no pretende imponerse como regla inflexible y rígida que no sea rebatible, sus aspiraciones son el acercamiento, la pretensión de conocimiento y no la de postulados imperativos, es el cincel con el que se pica en la piedra dramática con el fin de encontrar de entre cientos o miles una forma de visión posible.

En este aspecto, la teoría de los siete géneros propone diversos elementos de análisis que, de acuerdo con el teórico que los estudie, pueden variar en número y nomenclatura, pero también se conservan dentro de los terrenos de la ideología y su funcionamiento y operatividad dentro de la sociedad que las acoge. En efecto, la íntima relación entre estructura e ideología permite entonces plantear y problematizar la noción de género que ya se ha venido anticipando, adscrita al discurso de la teoría dramática.

\subsection{Acercamientos a la especificidad del "Género"}

Autores como Raymond Williams, Maurice Blanchot o Benedetto Croce sostienen que una teoría de géneros es insustancial. Blanchot y Croce postulan que sólo existe la obra y su relación con la literatura, sin intermediario alguno. Williams propone una alternativa a los estudios dramáticos con conceptos como convención y estructura de sentimientos para explicar los cambios que ha experimentado el drama con el paso de los tiempos. Sin embargo, de manera implícita o explícita, no les es ajena la idea de cierta evolución en las formas literarias; evolución que no podría ser percibida, dice Todorov apoyándose en el mismo Blanchot, si 
cuando se identifica una nueva forma no se está igualmente identificando la vieja forma que se está abandonando. Además de que la transgresora, apenas admite su estatuto de excepcionalidad, se "convierte, a su vez, gracias al éxito editorial y a la atención de los críticos, en una regla". 25

El concepto de género es equiparable al de tradición y por mucho que se quiera renegar sobre su ser o su existencia, allí está. El campo literario ha cargado con sus descripciones desde Platón, así que por extensión, dentro de la llamada forma natural genérica que es el drama, como lo planteó Goethe, las consideraciones también son de vieja data, lo que demuestra que históricamente el aporte desde la perspectiva de los géneros dramáticos ha sido amplia y productiva.

Primero, quisiéramos llamar la atención sobre otro valor histórico que ha hecho de la teoría de géneros una herramienta legítima: aquella que consiste en su operatividad dentro de lo que podría ser el campo teatral, no sólo en México, sino en cualquier parte en donde se estudie y se haga teatro. En ese sentido, para Kurt Spang, la finalidad más provechosa del estudio de los géneros es que son "el suministro de un valiosísimo instrumental interpretativo irrenunciable para el filólogo y cualquier interesado". ${ }^{26}$ Coincide con tal postulado Todorov, quien ha dicho sobre los géneros que existen como una institución y por eso...

...funcionan como "horizontes de expectativas" para los lectores y como "modelos" de escritura para los autores [...] Por una parte, los autores escriben en función del (lo que no quiere decir de acuerdo con el) sistema genérico existente [...] Por otra parte, los lectores leen en función del sistema genérico que conocen por la crítica, la escuela, el sistema de difusión del libro o simplemente de oídas; aunque no es preciso que sean conscientes de ese sistema. ${ }^{27}$

En este punto recordemos que cualquier dramaturgo ha escrito para que la obra sea puesta en escena; así, en el proceso de construcción colectiva del montaje antes de que la obra se

${ }^{25}$ Tzvetan Todorov, El origen de los géneros, en Teoría de los géneros literarios, coord. Miguel Ángel Garrido Gallardo, Arco Libros, 1988, p. 33.

${ }^{26}$ Kurt Spang, Géneros literarios, Síntesis, Madrid, 1993, p. 22.

${ }^{27}$ Ibid. p. 38. 
exhiba, actores, directores, escenógrafos, luminotécnicos, diseñadores de arte y de audio, etc., no son precisamente "cualquier interesado", como se señalaba con Spang, sino una importante franja intermedia entre obra y espectador. Con esa perspectiva, a la hora de unificar criterios en beneficio de la unidad dramática y de representación, los implicados en el montaje son una combinación entre lectores y autores, pues por un lado les es natural generar un horizonte de expectativas en el momento en que leen el texto que se va a montar, para inmediatamente después empezar su labor creadora siguiendo el modelo genérico que se ha establecido -ya sea por parte del director o, en algunas ocasiones, del dramaturgo. Dicho modelo es interiorizados y de acuerdo con él, en una clara variación de la relación del autor con los géneros, llevar a cabo la exhibición al público.

Enfatizamos en esta idea porque la experiencia de la construcción colectiva de una obra funciona como bisagra entre las libertades que tienen tanto espectadores como autores y el establecimiento cerrado y "rígido" de los géneros que permiten su sana perduración más allá de un despectivo statu quo. Aquellos que están vinculados con el montaje tienen la obligación de comprender los sistemas genéricos vigentes o no para que, como decía Tovar, funcionen como lengua franca en el instante en que se comunican para construir la puesta en escena de una obra. Ésta es una clara diferencia entre el campo teatral y el campo literario ${ }^{28}$ cuando la discusión se centra en la existencia de los géneros, pues se podría decir que, de manera consciente o inconsciente, en el campo teatral hay guardianes de los géneros a la manera, guardando las distancias, especialmente las autoritarias, de la Real Academia Española con la lengua castellana.

Ahora, justamente por no ser autoritaria, sino una especie de sistema de pensamiento en

\footnotetext{
${ }^{28}$ Evidentemente usamos el concepto acuñado por Pierre Bourdieu. Asimismo, asumimos que el campo literario contiene al teatral, lo que no niega que se le confiera su propia autonomía.
} 
constante discusión, la teoría de géneros está llena de dudas y confusiones. Recuerda Virgilio Ariel Rivera que Luisa Josefina Hernández decía a sus alumnos: "No discutan mucho de géneros, -nos dijo-, la teoría de la composición dramática es algo nuevo en el mundo y los autores no logran aún coordinar sus conceptos. Luego resulta que las más de las veces, cuando se discute, sólo se está hablando de lo mismo con diferentes términos". ${ }^{29}$ Pavis afirma que la confusión terminológica se explica "por la multitud de criterios de distinción: rara vez puramente literarios y fundados en tipos de escritura, están siempre vinculados al contenido de la obra, al tipo de personajes, al sentimiento y al afecto producido en el público. En última instancia, dependen para su evaluación de los valores ideológicos de una época y de la jerarquía social". ${ }^{30}$ Como se ha venido exponiendo, no podemos contradecir lo dicho por Pavis. El inmanentismo a la hora del análisis genérico es casi imposible por la relación de éste con la realidad dada y su carga ideológica. Lo anterior guarda concordancia con el siguiente enunciado de Todorov:

A través de la institucionalización, los géneros comunican con la sociedad en la que están vigentes. Es también por este aspecto por lo cual interesarán más al etnólogo o al historiador. Así, el primero seleccionará, ante todo, de un sistema de géneros, las categorías que lo diferencien del de los pueblos vecinos, poniendo en correlación esas categorías con los demás elementos de la misma cultura. Lo mismo hará el historiador: cada época tiene su propio sistema de géneros, que está en relación con la ideología dominante. Como cualquier institución, los géneros evidencian los rasgos constitutivos de la sociedad a la que pertenecen. ${ }^{31}$

No se puede pensar que el sesgo circunstancial que traen consigo cualquier análisis de cualquier drama es motivo para invalidarlo, pues, como cualquier acto del lenguaje, con un locutor que enuncia, un destinatario a quien se dirige, con un tiempo y un lugar, le es inherente

\footnotetext{
${ }^{29}$ Rivera, op. cit., p. 23. No podemos precisar por qué Hernández dice que la teoría de la composición dramática es algo "nuevo en el mundo", así que nos limitamos a sospechar que la maestra estaba reforzando el argumento que aquí estamos exponiendo.

${ }^{30}$ Pavis, op. cit., s.v. "género".

${ }^{31}$ Todorov, op. cit., p. 38.
} 
un marco que contextualiza tal enunciación. ${ }^{32}$ Bajtín sustenta esta reflexión con la idea de que el uso de la lengua (que incluye a los géneros discursivos secundarios, o complejos como el texto teatral) se lleva a cabo en formas de enunciados "concretos y singulares que pertenecen a los participantes de una u otra esfera de la praxis humana. Estos enunciados reflejan las condiciones específicas y el objeto de cada una de las esferas no sólo por su contenido (temático) y por su estilo verbal, o sea por la selección de los recursos léxicos, fraselógicos y gramaticales de la lengua, sino, ante todo, por su composición y estructuración". ${ }^{33}$ Pero el autor ruso hila más fino y afirma que forma y contenido están unidos en la palabra, por tal razón, la palabra poética aquella considerada en un uso artístico- desborda los marcos de su concepción, revela la dialogalidad interna de la propia palabra y los fenómenos que la acompañan, condicionada a determinados destinos socio-históricos e ideológicos, y por tareas históricas especiales resueltos en diversas esferas sociales y en distintas etapas de su desarrollo histórico: "Estos destinos y tareas condicionaron tanto las variantes genéricas de la palabra ideológica como algunas orientaciones verbal-ideológicas y una concepción filosófica de la palabra -y particularmente de la palabra poética- que descansa sobre la base de todas las corrientes estilísticas". ${ }^{34}$

Pensado de esta manera, Bajtín no toma al lenguaje como un sistema de categorías gramaticales abstractas, sino como un lenguaje ideológicamente pletórico, como concepción del mundo y como opinión concreta que garantiza el máximo de comprensión mutua en todas las esferas de la vida ideológica. Subraya que el lenguaje en cada momento de sus desarrollo se divide en dialectos lingüísticos, en lenguajes socioideológicos, sociogrupales, «profesionales», «de género», de generaciones, etc. Asimismo y desde este punto de vista, la lengua literaria es

\footnotetext{
${ }^{32}$ De allí el importante papel que ha desempeñado la teoría de los siete géneros en el campo teatral mexicano, así que advirtamos que existen dos consensos, el de la claridad en su aparente definición y el de que no es un corsé que obliga su uso al pie de la letra.

${ }^{33}$ Mijail Bajtín, Estética de la creación verbal, trad. Tatiana Bubnova, Editorial Siglo XXI, México, 1990, p. 248.

${ }^{34}$ Mijaíl Bajtín, La palabra en la novela, en Problemas literarios y estéticos, Trad. Alfredo Caballero, Editorial Arte y Literatura, La Habana, 1986, p. 94-95.
} 
una más en esta diversidad lingüística, por lo que se amplía y profundiza en la medida en que el lenguaje vive y se desarrolla. ${ }^{35}$ Kurguinian y Steiner podrían acompañar estas afirmaciones, a las que Todorov complementaría al afirmar que:

...una sociedad elige y codifica los actos que corresponden más exactamente a su ideología; por lo que tanto la existencia de ciertos géneros en una sociedad, como su ausencia en otra, son reveladoras de esa ideología y nos permiten precisarla con mayor o menor exactitud. No es una casualidad que la epopeya sea posible en una época y la novela en otra, ni que el héroe individual de ésta se oponga al héroe colectivo de aquélla: cada una de estas opciones depende del marco ideológico en el seno del cual se opera. ${ }^{36}$

Para concluir, podemos decir que el teatro como acontecimiento artístico, como gran género con vida propia, requiere el estudio de sus rasgos constitutivos, de la relación que hay entre sus subgéneros, para poner de manifiesto, diría Kurguinian, "la especificidad sustancial de la forma, e igualmente las premisas históricas que le dan vida, dan forma y determinan el desarrollo posterior, la transformación, un mayor perfeccionamiento o la descomposición, la degradación de ésta" ${ }^{37}$ Es la llave, concuerda Pavis, para una comprensión de todo texto en relación con un conjunto de convenciones y normas (que precisamente definen cada género). Finalmente, Todorov provee a la noción de género de una condición que quizá a Williams, Blanchot y Croce no les caería muy bien: "el género es el lugar de encuentro de la poética general y de la historia literaria; por esa razón es un objeto privilegiado, lo cual podría concederle muy bien el honor de convertirse en el personaje principal de los estudios literarios". 38

En lo que respecta a México, la teoría de los siete géneros se asume como una noción de reconocida relevancia y una institución, al ser considerado "el más amplio, el más divulgado y

\footnotetext{
${ }^{35}$ Ibíd., pp. 96-97.

36 Todorov, op. cit., pp. 38-39.

${ }^{37}$ Kurguinian, op. cit., pp. 20-21.

38 Todorov, op. cit., p. 39.
} 
el más razonado de cuantos andan por ahí". ${ }^{39}$ Como se anticipó, para la misma época en que Hernández establecía su teoría con siete géneros, para Bentley eran suficiente cinco, como señala Tovar: "Una pareja de altos (tragedia y comedia), otra de bajos (melodrama y farsa), y la dual tragicomedia. Fue colaborador de Brecht, pero no se le ocurre que las Lehrstücke de éste puedan corresponder a un género aparte; Hernández, en cambio así lo piensa, relacionándolas con los autos sacramentales, e incluye en su esquema la 'obra didáctica', amén de la pieza”. ${ }^{40}$ Seguidamente hacemos un pequeño resumen de cada uno de los siete géneros propuestos por Hernández, teniendo en cuenta que es una glosa simple, pero necesaria para ubicar a la pieza, y sin desentendernos de los problemas teóricos que traen estas definiciones y que justamente, con respecto a la pieza, trataremos de aclarar más adelante.

Tragedia: es un género realista de concepción temática, lo que quiere decir que al poeta le preocupa, más que la acción en sí, el sentido de la acción, su significado. Su personaje principal posee grandes cualidades pero también un defecto que dadas las circunstancias ocasionan su destrucción. Y expone en un plano humano los ciclos de orden y desorden por los que el cosmos se mueve.

Comedia: expone un problema social, y el héroe lo soluciona mediante el absurdo. $\mathrm{Su}$ renovación llevó a plantear el problema social sobre su protagonista, quien no está carente de cualidades pero a su vez posee un molesto y constante vicio de carácter que amerita su escarmiento.

Melodrama: género anecdótico que emociona y divierte con historias de conflicto entre el bien y el mal, encarnados como valores en personajes "buenos" y "malos". Es importante que las emociones manifestadas sean fuertes y expresadas en tono altisonante. El destino del héroe

\footnotetext{
39 Tovar, op. cit., p. 60. La síntesis que sigue sobre los géneros asociados dentro de la teoría de los siete géneros tiene como fuente dicha obra.

40 Ibid., p. 60.
} 
tiene dos posibles desenlaces: vence en el conflicto gracias a sus virtudes o es vencido a pesar de éstas.

Tragicomedia: El héroe tiene una meta, la persigue enfrentando obstáculos y la alcanza o no. Una meta positiva implica obstáculos negativos y corresponde a un personaje serio; si la meta es negativa el personaje es cómico y enfrenta obstáculos positivos.

Obra didáctica: Como se intuye, pretende impartir una enseñanza que induzca a una acción concreta acorde a la ideología que se expone como positiva en la obra.

Farsa: género camaleónico que opera sobre los otros, sustituyendo sus elementos y engendrado así la farsa trágica, la farsa cómica, etc. Produce una catarsis que en apariencia no tiene sentido.

Pieza (reproducimos literalmente lo dicho por Tovar):

Es el género más realista, al grado de que puede decirse que allí, como en la vida misma, nunca pasa nada. Requiere, por eso, para que el respetable no se aburra, una sutil gradación de intensidades y, para ello, una gran atención a la forma. Los personajes son seres mediocres en situaciones mediocres, pero al principio del drama tienen la esperanza de mejorar, al final las han perdido y eso es de hecho todo lo que ocurre. El resultado es una catarsis a medias, sin purificación alguna: sufrimos con los personajes y al terminar la representación seguimos sufriendo por ellos, por nosotros mismos y por la humanidad en general. ${ }^{41}$

Con esta idea general, nos permitimos seguir con una exposición del origen del género pieza.

\subsection{Raíces humanas, sociales y estéticas de la pieza}

Si hemos de concordar con el maestro Usigli, los antecedentes de la pieza como práctica poética teatral se remontan a la segunda mitad del siglo XIX y a autores del continente europeo.

${ }^{41}$ Ibid., pp. 62-63. 
La Revolución Francesa y el comienzo de la Revolución Industrial a finales del siglo XVIII generaron transformaciones en todos los aspectos de la vida de los habitantes del llamado Viejo Continente, especialmente en los rubros de la economía, la política y la cultura. Las consecuencias en un ámbito general se vieron en la "marcha hacia la democracia social y política. [Pero] En la educación pública se registró un progreso más lento, en tanto que la población de las ciudades capitales y de los centros industriales crecían a una tasa enorme". ${ }^{42}$

El teatro fue susceptible a las convulsiones que se vivían, y mientras unos autores procuraron transformar sus espíritus creativos tomando distancia de la tradición, otros aprovecharon el crecimiento de las urbes ofreciendo recetas exitosas ya probadas a un público sin gran preparación educativa, pero con dinero suficiente para pagar el boleto de una exhibición que les ofreciera un "escape del mundo en que vivían y trabajaban". ${ }^{43}$ Los teatros aumentaron en número, aunque poco a poco fueron reduciendo su tamaño (quizá en consonancia con un drama más intimista); las actuaciones desarrollaron una forma naturalista que se adaptaban a las obras realistas que se imponían como estilo; la ciencia trajo consigo la iluminación técnica; los decorados también se estilizaron acordes a la precisión histórica, los escenarios abandonaron las bambalinas y las cortinas, y llegó el realismo del decorado de medio cajón que "representa las tres paredes y el techo de un interior, siendo la cuarta pared la bocaescena". ${ }^{44}$ Para Macgowan y Melnitz, el progreso dado en este periodo con respecto al teatro sólo puede equipararse al del siglo $\mathrm{V}$ antes de Cristo y al de los siglos del Renacimiento.

Justamente desde el Renacimiento se "descubrió a la razón como medio para entender al hombre y a las fuerzas que lo rodean. Causa y efecto se convirtieron en las manifestaciones de

\footnotetext{
${ }^{42}$ Kenneth Macgowan y William Melnitz, Las edades de otro del teatro, Fondo de Cultura Económica, México, 1992, p. 218.

${ }^{43}$ Ibid., p. 219.

${ }^{44} \mathrm{Id}$.
} 
un universo coherente. Como premisa básica se estableció que el hombre es un ser capaz de dignidad, que puede vivir mejor en un mundo de racionalidad humana y que su vida vale la pena para ser vivida". ${ }^{45}$ El proceso fue lento, el arte pasó del clasicismo al romanticismo, cuya forma se afianzó hacia 1770, "glorificó al individuo y exaltó la emoción contra el racionalismo de Voltaire. En el teatro, los autores repudiaron las reglas clásicas aunque rindieron culto a Shakespeare, en su mayor parte escribieron en prosa en lugar de servirse del verso. Si sus diálogos tenían cierta cualidad de naturalidad, la inspiración y la atmósfera de sus obras eran románticas". ${ }^{46}$

Entre 1850 y 1900, expone Wright, "cuatro teóricos cambiaron el mundo e introdujeron las mayores innovaciones hasta ese entonces conocidas en lo que se refiere a la sustancia de la obra teatral". ${ }^{47}$ Charles Darwin y su teoría de la evolución revolucionaron lo referente a las concepciones biológicas y religiosas; Karl Marx y sus teorías sobre el capital, la lucha de clases y el materialismo dialéctico agitarían las bases de los estamentos sociales y económicos; por su lado, la definición del inconsciente y demás mecánicas de la psiquis humanas fueron los aportes de Sigmund Freud que también replantearon las concepciones sobre la sexualidad y la psicología; y por último Friedrich Nietzsche, quien criticó de fondo las ideas que integraban los conceptos tradicionales de cultura, religión y filosofía occidental. Sin duda el siglo XIX, como periodo de desarrollo social y artístico, significó un punto de eclosión de matices de ideas filosóficas, artísticas, sociales, políticas, culturales, etc., que se venían cocinando desde hacía unos siglos antes y que resultaron en un sentimiento de época que Erich Auerbach sintetiza como un malestar producto de tales movimientos:

\footnotetext{
45 Edward A. Wright, Para comprender el teatro actual, Fondo de cultura económica, México, 1992, p. 87.

${ }^{46}$ Macgowan y Melnitz, op. cit., p. 220. El paso del verso a la prosa será crucial, idea que ampliaremos más adelante.

47 Wright, $O p$. cit., p. 87.
} 
La efectividad de la religión había sido más quebrantada en Francia que en ningún otro lugar, las instituciones políticas estaban en perpetuo cambio y no ofrecían ninguna consistencia interna; las grandes ideas del racionalismo y de la Revolución se habían desgastado con asombrosa rapidez, convirtiéndose en frases hechas: su resultado había consistido, en resumidas cuentas, en una enérgica pugna de los egoísmos, considerada como justa, por cuanto el trabajo libre era mirado como la condición natural y autorreguladora del bienestar general y del progreso. ${ }^{48}$

Asimismo, las nuevas responsabilidades que debía asumir el hombre tras entender que estaba ante sus propias determinaciones trajeron consecuencias que por primera vez había que enfrentar:

Pero la autorregulación no funcionaba de suerte que las necesidades fueran satisfechas con justicia: sobre el éxito y el fracaso del individuo y de las clases enteras no deciden solamente la inteligencia y el celo, sino el punto de partida, las relaciones personales, los golpes de la suerte y, no muy raramente, una robusta falta de conciencia. Desde luego que nunca había marchado el mundo según la justicia, pero ahora ya no era posible interpretar seriamente la injusticia como disposición divina, aceptándola como tal. Se produjo en seguida un violento malestar moral, pero el empuje del movimiento económico era demasiado fuerte para que pudieran detenerlo frenos puramente morales: coexistieron la voluntad de expansión económica y el malestar moral. $^{49}$

Nuevos conflictos emergieron producto de las dinámicas citadas por Auerbach, las

polarizaciones no se hicieron esperar y acarrearon consigo conflictos que aún son latentes en

nuestra sociedad:

Poco a poco fueron destacándose los peligros reales que amenazaban al desarrollo económico y a la estructura de la sociedad burguesa, la lucha de las grandes potencias por los mercados y la amenaza del "cuarto estado" [el proletariado], que empezaba a organizarse; se gestaba la preparación de la gran crisis cuyo estallido hemos vivido y estamos viviendo aún. En el siglo XIX muy pocos poseían una inteligencia sintética que apreciara en su justo valor las fuentes más importantes de peligro, y quizá los que en menor grado la poseían eran los hombres de estado: la mayor parte estaban ocupados con ideas, anhelos y métodos que les impedían comprender la situación económica y la elementalmente humana. ${ }^{50}$

Quizá el malestar que llevó a los dramaturgos a una búsqueda y representación de formas

serias en las que subyacieran verdaderos sentimientos trágicos y no simples fachadas trágicas en

las que se representarán las cuestiones humanas que se podrían implicar de la exposición de

\footnotetext{
${ }^{48}$ Erich Auerbach, Germinie Lacerteux, en Mimesis, la representación de la realidad en la literatura occidental, Fondo de Cultura Económica, México, 1996, p. 472.

${ }^{49} I d$.

${ }^{50}$ Ibid., pp. 472-473.
} 
Auerbach se debían justamente a los objetivos que procuraba el género que gozaba de más popularidad en la Europa de mediados del XIX: la pièce bien faite (pieza bien hecha).

Señala Raymond Williams en El teatro de Ibsen a Brecht ${ }^{51}$ que para el tiempo en que Ibsen pasó una temporada desempeñándose como productor $\mathrm{y}$ director en Bergen, en ese entonces aún la ciudad más importante de Noruega, se presentaron allí ciento cuarenta y cinco obras, de las cuales setenta y cinco eran francesas, y las describía como las típicas obras: “...de intriga dramática, basada en un complicado enredo, que se movía rápidamente alrededor de ciertas escenas habituales. El documento confidencial mostrado en público; la copa envenenada que pasa de mano en mano, y acaba siendo bebida por alguien distinto a la pretendida víctima; el niño raptado identificado por un talismán secreto o por una marca de nacimiento[...] La acción era variada, complicada y continua con el fin de despertar interés, sorpresa y

\footnotetext{
${ }^{51}$ Raymond Williams, El teatro de Ibsen a Brecht, Ediciones Península, Barcelona, 1975. Como se anticipó, Williams afirma que una teoría de los géneros es totalmente nula. Afirma que no se le pueden aplicar eficazmente "los términos y procedimientos críticos que fueron ideados para la comprensión de obras anteriores" (p. 391). Apunta que las nociones de género son heredadas de jerarquías, separaciones, y reglas fijas. Por tal razón, su propuesta crítica ofrece las nociones de estructura de sentimientos y convención: "Tenemos necesidad de tradición -convención como acuerdo tácito- y al mismo tiempo necesidad de experimentación, del desarrollo de nuevas formas de sentimiento, de la percepción de medios técnicos nuevos o redescubiertos -convención como método dramático" (pp. 16-17). A grandes rasgos, las verdaderas convenciones son más que métodos y técnicas que pueden ser usados satisfactoriamente para crear una obra de arte a través de la representación (Id.). Las estructura de sentimientos son los elementos que subsisten al análisis, a la comparación de la obra con las distintas partes separables, y para los que no existen medidas externas: "Se trata de algo tan firme y definido como el término «estructura» sugiere, y se basa, sin embargo en los elementos más profundos y a veces menos tangibles de nuestra experiencia. Es un modo de responder a un mundo particular que no se siente en la práctica como uno entre varios -un «modo» consciente-, si no que es, de hecho, el único modo posible" (pp. 18-19). Así, afirma que hay en la evolución artística elementos que perduran de manera decorativa pero que han perdido correlación con la sociedad en la que se mantienen. Pero a su vez, nos dice que ha habido talentos individuales con capacidad de crear obras con el valor suficiente de modificar viejas concepciones, posibilitar la transformación de tales elementos decorativos y crear el puente que los conecte con un sentir más propio de la época en la que surgen. Como se ve, Williams es tajante en su postura sobre los géneros, aunque en otra parte diga "que toda consideración seria sobre el arte debe comenzar por reconocer dos sucesos que en apariencia son contradictorios: "que una obra importante es siempre, en un sentido, irreductible e individual; y que existen a la vez auténticas comunidades de obras de arte, en géneros, periodos y estilos" (p. 18). Con esto queremos señalar tres cosas. La primera, que la visión que se ha tratado de transmitir es la de los géneros en tanto acercamiento al objeto dramático y no como dogma formal y jerarquico; segundo, que, como se ve, el mismo Williams aprecia su utilidad y más cuando los géneros operan como convención que potencializa la creación individual; y por último, que la manera en que despliega sus nociones sobre los autores que analizaremos como gérmenes de la pieza son de gran útilidad para entender dicha evolución, como lo expondremos.
} 
expectación". 52

La objeción más conocida a estos artificios, dice Williams, es que: "la vida no es así'. 53 Según Pavis, la expresión Pièce bien faite se atribuye al prolífico escritor Eugene Scribe, ${ }^{54}$ quien junto a otros autores como Sardou, Labiche, Feydeau y el mismo Ibsen construían sus obras siguiendo la misma receta de intriga y organización perfecta de su acción. ${ }^{55}$ Pavis no duda en anotar algo verdaderamente importante para el devenir del teatro con respecto a estas obras: "La dialéctica entre fondo y forma - la búsqueda de una forma adecuada a un contenido y viceversa- es pues completamente inexistente: no hay un desarrollo orgánico del uno y por el otro, sino aplicación mecánica de un esquema tomado de un modelo clásico caduco. La obra bien hecha es la culminación y probablemente el 'acabamiento' (paródico sin saberlo) de la tragedia clásica". ${ }^{56}$ Por su parte, Williams plantea un ejemplo de la evolución histórica de la tragedia clásica griega en su estructura de sentimiento y en sus convenciones que desembocó en tal acabamiento e hizo emerger la Pièce bien faite:

las escenas griegas de reconocimiento y malentendido eran la más seria experiencia de la época: la dificultad esencial que, desde cualquier punto de vista, planteaba la compresión del verdadero carácter de las fuerzas que se creía determinaban la historia del hombre, a través de las acciones de los dioses y del destino [...] En las escenas renacentistas, están aún presentes elementos de este designio fatal y sobrenatural. Signos, coincidencias y lo que parecen casualidades, reflejan un orden providencial más amplio, normalmente presentado de modo menos directo, pero presente en las peripecias de la acción. Hay también un nuevo y específico interés en la herencia, con todas sus connotaciones de autoridad legal y falsa, decisivo en la sociedad feudal y en la posfeudal, y las escenas de reconocimiento están a menudo relacionadas con esto. Tanto en el drama griego como en el renacentista, se dan ciertamente casos en que las convenciones originadas en una importante estructura de sentimiento se convierten, dentro del periodo, en artilugios teatrales. [...] Sin embargo, mientras se mantienen las obras importantes, la forma dramática convencional está aún profundamente relacionada con la experiencia seria.

En la época del teatro de intriga esta relación había desaparecido [...] Las tramas y el conjunto de personajes, los artificios y las situaciones, no expresaban ya la conciencia de un orden externo determinante, con sus problemas críticos de reconocimiento y comprensión, ni la

52 Ibid., p. 29.

${ }^{53} \mathrm{Id}$.

${ }^{54}$ Por su parte, Macgowan y Melnitz dicen que el término lo acopló Bernard Shaw reprobando las obras de Scribe y compañía.

${ }^{55}$ Pavis, op. cit., s.v. pieza bien hecha.

${ }^{56} I d$. 
importancia general de la herencia en sus bases públicas de inocencia y autoridad. Privados de estas experiencias determinantes [...], los métodos del antiguo teatro se transforman en puros artilugios [...] La concha brillante está aún presente, pero el cuerpo que contenía está muerto ya. Concepciones nuevas del destino y de la responsabilidad, nuevos sentidos de las relaciones y de la personalidad, nuevos enfoques de la psicología y de la motivación, necesitan convenciones nuevas para poder surgir como teatro. ${ }^{57}$

Además, propone una explicación al trasegar que llevó a que, por ejemplo, la tragedia griega sufra una severa transformación y que en este caso advino, entre las formas posibles de evolución, en la pieza bien hecha:

Lo que tenemos realmente que entender es todo ese complicado proceso, en el cual una determinada estructura de sentimiento, que encuentra su forma efectiva en determinadas convenciones dramáticas, se derrumba en el curso del desarrollo histórico, pero durante un tiempo - un largo tiempo a veces- sobrevive en sus características externas. Debemos decir que las convenciones están aún ahí; son sin duda bien entendidas y localmente efectivas; pero sobreviven principalmente a un nivel técnico, y la estructura de sentimiento que controla, y la serie de graves intereses contenidos y expresados en ella, no están ya realmente presentes. ${ }^{58}$

Así que, a pesar de su fama, de su popularidad entre el público, los escritores y las compañías, quienes exigían y mantenían las formas teatrales que pretendían el éxito comercial, la pieza bien hecha no lograba el nivel de representación necesaria como para que su mimesis lograra la suficiente cualidad de reflejar la vida, como lo plantea Williams, por todos los artilugios que se concentraban sólo en la trama. Bentley referente a dicha circunstancia es tajante:

Esta clase de teatro es "todo trama", y aun cuando uno no conozca piezas bien hechas puede comprender por qué el género terminó por ganarse enemigos entre los intelectuales. Siendo todo trama, nada le quedaba para apresar en su red o para chocar contra ello. Estaba lleno de agitación, pero no se movía en una dirección particular. No nos trasmite el "sentimiento de algo que nace y se desarrolla y luego declina" [...] Esta clase de drama menos intelectual -este teatro para no intelectuales-adolece de una falta, no de cerebración, sino de emoción. Por cierto, consiste en una estratagema para crear una emoción -la punzadura del suspenso-, pero le es imposible acceder a las demás emociones. Y es organizado sólo por la inteligencia, si es lícito involucrar en el concepto de "inteligencia" la posesión de una destreza teatral. Con mayor frecuencia empleamos la palabra "destreza" para referirnos a una habilidad mecánica, y la pieza bien hecha es elaborada a partir de un esquema mecánico, y no, como ocurre realmente con las obras de arte auténticas, a

${ }^{57}$ Williams, op. cit., pp. 30-31.

${ }^{58}$ Ibid., p. 30. 
partir de un esquema orgánico [...] El error en la clase de piezas bien hechas estribaba en el aislamiento de su trama con respecto a los demás elementos de la obra. ${ }^{59}$

Los vientos de grandes cambios habrían de empezar a sentirse, y de manera retrospectiva podemos convenir en que la semilla de lo que vendría a ser la pieza ocurrió gracias al cansancio acaecido por la pieza bien hecha y que ésta a su vez aparecía en el panorama de las artes escénicas como un género que estableció la "culminación" y probablemente el "acabamiento" de la tragedia clásica. Las características que le determinarían se vendrían a dar por elementos propios, esencialmente aquellos dados por el establecimiento de un hombre y una sociedad moderna en cuyo seno empezaron a perder vitalidad convenciones que fueron abandonadas por sus estructuras de sentimiento, si lo entendemos a la manera de Raymond Williams. Como precursor de éstas circunstancias podemos señalar a Henrik Ibsen.

Ibsen, quien vivió entre 1828 y 1906, es reconicido como introductor del estilo realista en el teatro. ${ }^{60}$ Esto quiere decir que hay una intención estética de interpretación de la realidad, seleccionando el material y estructurándolo; éste estilo enfoca las minucias y los pormenores del cotidiano de la existencia en las que se exhiben sin discriminación lo feo y lo bello de la vida; tal pretensión estética busca hacer emerger los problemas más íntimos del hombre y el diálogo de los personajes se expresa de manera naturalista o como comúnmente se encuentran a las personas hablando en su devenir diario.

Al respecto, Williams cita a Ibsen cuando escribió una carta a su editor acerca de La unión de los jóvenes: "«será en prosa y totalmente adaptada a la escena.» Había decidido abandonar el verso y cultivar «el arte mucho más difícil de escribir en el auténtico y sencillo lenguaje

\footnotetext{
${ }^{59}$ Bentley, op. cit., pp. 32-34.

${ }^{60}$ Wright, op. cit., p. 125.
} 
hablado de la vida real»". ${ }^{61}$ También al hablar sobre el Emperador y Galileo sugiere su programa:

La ilusión que quise producir es la de la realidad. Quise dejar en la mente del lector la impresión de que lo que había leído era lo que sucedía realmente. Si hubiese empleado el verso hubiese traicionado mis propósitos. Los diversos personajes vulgares e insignificantes, que intencionadamente he introducido, hubiesen quedado indiferenciados, y se hubiesen confundido unos con otros, si los hubiera puesto hablar con una medida rítmica. Ya no vivimos en la época de Shakespeare... el estilo debe acomodarse al grado de idealidad atribuido al conjunto de la exposición. Mi obra no es una tragedia en el sentido antiguo. Fue mi intención pintar seres humanos y, por ello, no debo hacerles hablar con el lenguaje de los dioses. ${ }^{62}$

Dice Steiner que en sus comienzos la tragedia griega estuvo escrita en verso, especialmente si acordamos su origen en rituales de celebración en que no se podía separar el empleo del lenguaje en una forma lírica realzada. Devino entonces que las verdades de la mitología o de las experiencias religiosas se expresaban con una "verdad poética" ajena a cualquier calificación empírica. Es ése el lenguaje de los dioses que crítica Ibsen. Para Steiner, “no sólo el verso es el guardián propio de la verdad poética contra la crítica del empirismo. Es el límite primordial entre el mundo realzado de la tragedia y el mundo de la existencia ordinaria. Reyes, profetas y héroes hablan en verso, mostrando así que los personajes ejemplares de la colectividad se comunican de un modo más noble y más antiguo que es reservado para los hombre comunes". 63

Aceptar la afirmación de que el verso construye una valla entre la tragedia y el auditorio repercute de manera relevante. Steiner explica que el verso opera como una simplificación y una complicación de la representación del comportamiento humano en la que la simplificación despoja de la vida los "estorbos de la contingencia material" (los hombres que hablan en verso no son propensos a resfriarse ni a sufrir de indigestión); y la complicación se da en el alcance y

\footnotetext{
${ }^{61}$ Ibid., p. 50.

${ }^{62} \mathrm{Id}$.

${ }^{63}$ Steiner, op. cit., p. 201.
} 
los valores del comportamiento del espíritu: "En virtud de la elisión, la concentración, la oblicuidad y su capacidad para sostener múltiples significados, la poesía proporciona una imagen de la vida que es mucho más densa y más compleja que la prosa". ${ }^{64} \mathrm{Si}$ habíamos concordado en la idea de que en el siglo XIX el teatro viviría uno de sus más grandes cambios, Steiner lleva más allá esta afirmación y sostiene que "con Ibsen la historia del teatro vuelve a empezar" ${ }^{65}$ La preocupación de Ibsen por producir la ilusión de realidad, de "dejar en la mente del lector la impresión de que lo que había leído era lo que sucedía realmente" se puede sostener con el argumento de Steiner de que la sintaxis de la prosa "encarna la función central que las relaciones causales y la lógica temporal desempeñan en los procesos de pensamiento corriente". ${ }^{66}$ Más acorde con el fluir desordenado de la vida cotidiana. Y si bien Ibsen no está innovando al incorporar la prosa en sus obras, pues en algunas comedias ya se venía haciendo desde hacía tiempo, su peculiaridad se da por la manera en que combina este recurso con los temas que encarnan parte de su propia vida espiritual superpuestos con los temas históricos escogidos y la estrecha relación con los movimientos sociales de su época.

No obstante, obras de Ibsen como La unión de los jóvenes o Los pilares de la sociedad, plantea Williams, no dejan de ser bisagras entre el melodrama romántico y el naturalismo, donde confluyen descripciones de política local pero que igual los mecanismos de la trama descansan en los artificios característicos de la pieza bien hecha. Para Steiner esto es completamente revolucionario, pues la orientación de "recursos tan gastados como el pasado oculto, la carta robada o la revelación en el lecho de muerte [...] hacia problemas sociales graves y urgentes," responsabiliza a esos elementos “de un propósito intelectual, deliberado [...] Nunca teatro alguno ha tenido tras sí un más poderoso impulso de la voluntad y tan explicita

\footnotetext{
${ }^{64}$ Ibid., p. 204.

${ }^{65}$ Ibid., p. 241.

${ }^{66}$ Ibid., p. 204.
} 
filosofía social". ${ }^{67}$

Durante la escritura de aquellas obras, Ibsen estaba ya pensando en quizá su obra más comentada: Casa de muñecas. Se pregunta Williams qué la hace tan original, si los personajes y las situaciones difieren poco de los del drama romántico: la inocente mujer infantil, el marido torpe e insensible, el amigo fiel; el secreto culpable, los labios sellados, la compilación de la situación alrededor de la reveladora carta de Krogstad, el villano en contra de un ambiente idílico de felicidad. Para Williams, la novedad está en que "estas muñecas, deliberadamente románticas, son repentinamente arrojadas a la vida." Hay afirmaciones en las palabras de Nora en vez de discusiones, y cuando Torvald pregunta a Nora no es más que un mecanismo retórico, dispuestas para que ella exprese lo que vendría siendo la moral de la obra:

NORA: Puedes decir, ¿no tengo una guía infalible en cuestiones como éstas? ¿No tengo religión? Puedo solamente responder que nada sé, excepto lo que el pastor Hansen me dijo cuando me confirmó. Él decía que la religión era esto y lo otro. Cuando lo abandoné todo y quedé sola, medité sobre ello también. Quería ver si lo que él me enseñó era correcto, o en todo caso, si era válido para mí.

Sobre la paleta de recursos de Ibsen en Casa de muñecas Williams plantea lo siguiente:

La realidad es del mismo género limitado y se presenta conforme a las últimas convenciones [...] La obra no va más allá del mecanismo habitual del teatro de intriga, sin socavar los supuestos del teatro romántico, con sus interpretaciones mecánicas de la experiencia; únicamente aporta una reversión dentro de la estructura romántica. No es un nuevo modelo dramático positivo; es sencillamente anti-romántico, una negación dentro de la misma estructura de realidad [...] rechaza conclusiones; no se atacan los tipos limitados de realidad. Sólo si acudimos a El padre o a La danza de la muerte de Strindberg [...] comprobaremos hasta qué punto esto es verdad [...] el calificativo de «obra problemática» u «obra de tesis» está justificado. [...] El rechazo que Ibsen hace del fin moral convencional es sólo una cura limitada de este mal, una negativa parcial dentro de una esencial aceptación. [...] Casa de muñecas, pues, es una obra anti-romántica, en el sentido que hemos definido de negación limitada. El Naturalismo, tal como se ha practicado generalmente, es antiromántico en el mismo limitado sentido. Strindberg, como veremos más tarde, pugna porque el Naturalismo alcance a restaurar la sustancia total. Pero el naturalismo que acabó dominando el teatro, fue del género más limitado. Es en este sentido en el que debe subrayarse que el naturalismo es hijo legítimo del drama romántico; un hijo que hace un repudio limitado de sus padres y que permanece esencialmente fiel a su herencia genérica. ${ }^{68}$

${ }^{67}$ Ibid., pp. 241-242.

${ }^{68}$ Williams, op. cit., pp. 56-57. 
Williams también hace observaciones sobre obras del autor noruego como Espectros, Un enemigo del pueblo, El pato salvaje, Rosmersholm, Hedda Gabler, en las que se muestra la evolución del método dramático de Ibsen. En ellas van la retórica contra la maciza y complaciente mayoría liberal; el ataque hacia la devoción sentimental hacia «las masas»; la insistencia sobre el principio aristocrático; la declaración de la función de la minoría consciente. Todo lo que forma un programa liberal. Son obras que presentan una rica selección de personajes, tramas interesantes y considerables cargas de emoción. Así, llega a la conclusión de que Ibsen, más que cualquier otro, contribuyó a crear la conciencia moderna del teatro europeo. Con estas observaciones también coincide Steiner, quien matiza al resaltar que éstas

piezas panfletarias, por duraderas que resulten en virtud de su vigor teatral, no son tragedias. En la tragedia no hay remedios temporales.[...] La tragedia no se ocupa de dilemas seculares que pueden solucionarse mediante la innovación racional sino de la propensión inalterable a la inhumanidad y la destrucción en el curso del mundo. Pero en dichas piezas, del periodo reformista de Ibsen, no es esta la cuestión que se trata. Hay remedios específicos para los desastres que les acaecen a los personajes y el propósito de Ibsen es hacernos conscientes de la existencia de tales remedios para que los administremos. Casa de muñecas y Espectros se fundan en la convicción de que la sociedad puede progresar hacia una concepción adulta y cuerda de la vida sexual y que la mujer puede y debe ser realzada a la misma dignidad del hombre. Pilares de la sociedad y Un enemigo del pueblo son denuncias de la hipocresía y opresiones que se esconden tras la máscara de la pulcritud burguesa. ${ }^{69}$

Más que señalar el acabamiento de la tragedia, trasciende en Steiner el resaltar que Ibsen cargó consigo la tarea de edificar una nueva mitología efectiva para el drama, puesto que la decadencia de la tragedia "está indisolublemente asociada a la decadencia de su cosmovisión orgánica y su consiguiente contexto de referencia mitológica, simbólica y ritual". ${ }^{70} \mathrm{Y}$ complementa afirmando:

Ibsen se halló frente a un verdadero vacío. Tenía que crear para sus piezas un contexto de significado ideológico (una mitología eficaz) y tenía que idear los símbolos y las convenciones teatrales que permitieran transmitir su significado a un público corrompido por las fáciles virtudes del escenario realista. Estaba en la situación de un autor que inventa un nuevo idioma y debe

\footnotetext{
${ }^{69}$ Steiner, op. cit., p. 242.
}

${ }^{70}$ Ibid., p. 243. 
enseñarlo a sus lectores [...] Tomó como punto de partida la precariedad de la fe moderna y la falta de un mundo imaginativo. El hombre va desnudo por un mundo despojado de mitos explicativos o conciliadores. El teatro de Ibsen presupone la retirada divina de los asuntos humanos y que esa retirada ha dejado una puerta abierta para que por ella se cuelen heladas ráfagas que vienen de una creación maligna aunque inanimada. [...] Ibsen se basa en la noción moderna de que hay rivalidad y desequilibrio en la psique individual. [...] Son fuerzas desorganizadoras que se han desencadenado desde lo más profundo del espíritu. ${ }^{71}$

Para Ibsen, según Steiner, esa fuerzas desorganizadoras son cánceres y el más maligno de todos es el "idealismo": "esa máscara de hipocresía y autoengaño que los hombres tratan de conservar frente a las realidades de la vida social y personal. Cuando los ideales se apoderan de un personaje de Ibsen lo llevan a la ruina psicológica y material", ${ }^{72}$

Por último, anticipemos una idea que quizá con Chéjov toma forma, que Williams señala en Ibsen y que especialmente involucra un efecto aleatorio en el surgimiento y evolución de la pieza que más adelante trataremos de exponer. Refieren a El pato salvaje y Williams lo plantea de la siguiente manera:

Pero el equilibrio de la obra resulta extraordinariamente delicado: lo que se escribe como un proceso externo -la dirección de la gente separada hacia el elemento que la conecta- puede transformarse en una serie de movimientos hacia adentro, de autoconciencia y autocontemplación; de hecho no la revelación del carácter en cualquier sentido general, sino la demostración, muy conscientemente presentada al público, de una especie de intimidad de espejo; movimientos hechos no para entenderse a sí mismo, sino para mostrarse a los demás, de una forma asequible. ${ }^{73}$

La cita podría parar allí, pero valga extendernos en la siguiente línea para simplemente hacer una acotación que sería bueno explorar más adelante en esta investigación: "Este procedimiento es ahora, claro está, un método total de actuación”. Quiere anticipar Williams, sin duda, lo que vendría a ser el método Stanislavsky, del cual anotaremos brevemente algo cuando hablemos de Chéjov, pero al que le cabe la misma pregunta que dirige a este trabajo: si la pieza como género tiene correlación con el tiempo que la vio nacer y desarrollarse, ¿acaso no

\footnotetext{
${ }^{71}$ Ibid., p. 244.

${ }^{72}$ Ibid., p. 244.

${ }^{73}$ Williams, op. cit., p. 67.
} 
pasa lo mismo con este método de actuación?

En resumen, Ibsen es un autor que pasó de una fuerte tradición romántica superando poco a poco los presupuestos artificiosos de la pieza bien hecha, decide tomar posición ante ello hasta llegar a plantear una propuesta más acorde a los tiempos que se estaban viviendo en ese momento en la Europa decimonónica: positivista, en el difícil proceso de consolidación de los estados de derecho, la emergente democracia o su correspondencia con las monarquías parlamentarias, la búsqueda de un individuo con aires liberales en tanto sus referentes de poder espiritual, poder económico, poder social y poder político, un individuo burgués que en las tablas ahora era reflejado más allá de su condición social y sus frívolos conflictos y que dejaba ver en sus acciones sus demonios internos. Cabe advertir que evidentemente Ibsen no usó sus obras como laboratorios sociales.

Pero si Wrigth define a Ibsen como un autor que "consideraba que ninguna verdad dura más de veinte años y que cada individuo debe evaluar constantemente las costumbres aceptadas de su época y la influencia de éstas en su propia felicidad”, Strindberg va más allá y dice que éste "pensaba que la autentica realidad se encuentra en la profundidad del subconsciente". 74

Johan August Strindberg nació en Suecia y vivió entre 1849 y 1912. Tradicionalmente siempre se hace un paralelo referencial entre este autor e Ibsen, con cierto aire de indiferencia hacia Strindberg; además se suelen señalar sus problemas de demencia con los que la crítica ha construido una fijación más hacia su biografía, enfatizando sus experimentos alquímicos, que a su obra. La versatilidad de sus dramas va, según Macgowan y Melnitzs, desde el drama histórico (Gustavo Vasa), la lucha sexual (La danza macabra), el drama religioso simbólico (Pascua) y aquellas en las que la vida se presenta con una extraña deformación que parece ser la base y raíz del expresionismo alemán (Camino de Damasco, La sonata de los fantasmas, La

\footnotetext{
${ }^{74}$ Wright, op. cit., p. 140.
} 
sonata del espectro, Ensueños).

Lo primero que habría que destacar en Strindberg es que, a diferencia de Ibsen, la trampa de la pieza bien hecha no lo capturó. Además tenía su propia concepción del naturalismo que Williams reproduce en la siguiente cita:

El naturalismo no es un método teatral semejante al de Becque, una simple fotografía que lo recoja todo, hasta la mota de polvo de la lente de la cámara. Esto es el realismo; un método, recientemente elevado a arte, un arte estrecho que no puede contemplar el bosque porque los árboles se lo impiden. Éste es el falso naturalismo, que cree que el arte consiste en la reproducción de un fragmento de naturaleza de un modo natural; pero eso no es el verdadero naturalismo, que busca las situaciones vitales en que los grandes conflictos se manifiestan, que se recrea en la visión de lo que no sucede habitablemente. ${ }^{75}$

Quizá por eso es que Steiner destaca en Strindberg el hecho de que en sus obras encontremos algunas "convenciones revolucionarias del último Ibsen, pero sin el sostén de una visión responsable de la vida". ${ }^{76}$ En la obra El padre, Williams nos propone una mirada a la realidad que expone Strindberg, acorde a su concepción de naturalismo citada anteriormente:

se propone como «una verdad revelada»; es evidente que, en la forma en que se presenta, no es una «realidad cotidiana». La distinción principal radica en la articulación de la exposición. Y no es que se trate de simplemente de una articulación de la imperfecta conversación de la gente normal. No es la articulación de la conversación real de las personas para hacerla más explícita, sino más bien de la percepción que el autor tiene de ciertos hechos ligados a la relación articulada por él. [...] Strindberg, más claramente que Ibsen en su periodo de Casa de muñecas a El pato salvaje, asumen el carácter convencional de sus personajes. Rechaza la carpintería formal de la obra bien hecha que Ibsen conserva tan a menudo. El padre es «informal» y se desarrolla a un solo nivel. Pero, si bien esto permite una expresión adecuada de la idea esencial (compárense los parlamentos de Laura y el Capitán con los de Nora y Torvald), la misma informalidad, la ausencia de «teatralidad», no hace si no reforzar la ilusión de que se está pretendiendo reflejar una observación directa. Y esta ilusión limita el logro de la expresión literaria esencialmente convencional. ${ }^{77}$

De la evolución del teatro de Strindberg y de su visión de la representación teatral se coligen dos vertientes que tienen como eje central el escrutinio que el autor hace de la psiquis humana. Por un lado nos heredó personajes en marcos realistas con complejos perfiles psicológicos y por el otro obras que, como bien se decía, por andar buscando verdades en el

\footnotetext{
${ }^{75}$ Strindberg citado por Williams, en op. cit., p. 92.

${ }^{76}$ Steiner, op. cit., p. 248.

77 Williams, op. cit., pp. 92-93.
} 
subconsciente antecederían al surrealismo ${ }^{78}$ y otras formas de expresión simbólicas. Según Steiner, Strindberg "no corresponde a la tradición predominante en el teatro trágico ni tiene a Ibsen como punto de partida. Está, con Kleist y Wedekind, en ese borde excéntrico en que el teatro no es una imitación de la vida sino, más bien, un espejo del alma individual". ${ }^{79}$ Por su lado, Williams llama a la actitud de Strindberg naturalismo crítico, puesto que su rechazo a lo que se conocía como naturalismo se debía a que era una "pasiva y conformista reproducción de una realidad superficial", y que por lo tanto lo que debía hacer el "escritor naturalista para expresar su nueva visión del mundo", era hallar en nuevos estilos dramáticos, "nuevas convenciones de la realidad". Esto especialmente en lo que tiene que ver con los personajes tipo: el estúpido, el brutal, el celoso. Para Strindberg éstos deben nutrirse de contenido en la medida de que reflejen la riqueza de los procesos anímicos, tal y como lo adelantamos con Steiner, donde se reconozca que "el vicio y la virtud tienen aspectos muy semejantes".

En ese sentido, Steiner señala que obras como Sonata de los espectros o Un sueño pertenecen al teatro de la mente y "actúan en nuestro interior como música que es recordada" y que en ellas si bien ganó en profundidad perdió en coherencia teatral. Efectivamente, para Strindberg, como dice Williams, no era el teatro [en su puesta en escena] el que necesitaba cambios, sino el drama en el teatro. Y no se refería necesariamente a aquellas obras algo más simbolistas que naturalistas como La sonata de los espectros con cierta complejidad de montaje. Williams lo expone con ejemplos tomados en su mayoría de La señorita Julia o El camino de Damasco. Considera que trabajó de la experiencia hacia el método sin dejarse presionar por las convenciones dramáticas de su época: "las nuevas convenciones se relacionan, directamente, con una estructura de sentimiento, y no pueden abstraerse de ella, como un simple

\footnotetext{
${ }^{78}$ Cfr. Wright, op. cit., p. 126.
}

${ }^{79}$ Steiner, op. cit., p. 249. 
modernismo" ${ }^{80}$ La señorita Julia para Steiner es una obra maestra, de la que destaca que "El tono elevado de los sentimientos y la gran susceptibilidad nerviosa que tienen como bases pueden manifestarse en una sola acción breve". Asimismo, no duda en señalar que "La concepción del mundo que está implícita en las piezas de Strindberg es histérica y fragmentaria. Jamás hubo otro dramaturgo que hiciera de una forma tan pública como el drama una expresión más privada". 81

En cierta manera, la estafeta de Ibsen y Strindberg la toma el escritor ruso Antón Pavlovich Chéjov, quien vivió entre 1860 y 1904. Acordemos primero que las fechas aquí nos han ayudado para efectivamente hacernos una idea de que justo en los últimos 40 años del siglo XIX había una conciencia colectiva entre los escritores que fue explorada de distintas maneras y que trajo como resultado las nuevas directrices de creación en los tiempos venideros. En este aspecto, Kurguinian es tajante al afirmar que si el Teatro del Arte a la cabeza de Stanislavsky desarrolló innovaciones cruciales para el arte dramático, "el Teatro del Arte descubrió en la obras de Chéjov las leyes del nuevo drama". ${ }^{82}$ Sin duda, dicha afirmación es un ladrillo en nuestra apuesta por construir un estatuto para la pieza, y más si Luisa Josefina Hernández coincide con ella al sostener que algunas obras del ruso "desconcertaron al mundo, siempre reducido, de los técnicos y críticos de teatro, porque no se adaptaban a una serie de reglas generales establecidas en principio por Aristóteles, pero sobre todo porque la producción literaria de más de veinte siglos fue considerada aristotélica, estricta en la necesidad de una corrección, de un estar en buenos términos con la teoría original”. ${ }^{83}$ Más adelante

\footnotetext{
${ }^{80}$ Williams, op. cit., pp. 115-116.

${ }^{81}$ Steiner, op. cit., p. 248.

82 Kurguinian, op. cit., p. 206.

${ }^{83}$ Luisa Josefina Hernández, La pieza como género dramático: el jardín de los cerezos, de Chéjov, en Los frutos de Luisa Josefina Hernández, aproximaciones y escritos de teoría dramática, Felipe Reyes Palacios y Edith Negrín editores, UNAM, México, 2011, p. 205. Dicho texto aparece originalmente como prólogo de El jardín de los cerezos, editorial Universidad Veracruzana, Xalapa 2003.
} 
profundizaremos en los postulados de Hernández; por lo pronto esbocemos la versión que ofrece Kurguinian de por qué Chéjov estipula nuevas leyes en el drama, a pesar de que, para que lo percibamos, nuestra intención haya sido la de plantear los cismas de los acontecimientos, aquellos que replantean los paradigmas, no como producto de un sólo factor sino de muchos, así como la misma Kurguinian a lo largo de su obra lo reconoce.

Para Kurguinian, la especificidad del drama, que le diferencia de la epopeya, es el hecho de que en el "drama, una situación expuesta es un blanco singular, predestinado para un juego concentrado y sistemático, cuyo fin es transformarla de una u otra manera" ${ }^{84}$ Mientras que la epopeya, el héroe homérico, está predestinado y no posee una determinación propia, "en el drama de la vida del hombre se percibe ante todo, precisamente por primera vez, como proceso, movimiento, cambio de impulsos, decisiones, y procederes humanos interrelacionados entre sí" ${ }^{85}$ Apoyada en V. N. Iarjo, apunta que el héroe homérico no tiene necesidad de sostener la acción, fundamentada en su propio albedrío: "Incluso, cuando en la conciencia del héroe se da la lucha entre dos ideas, ambas se toman como algo venido de afuera, y el triunfo final de una de las dos no es posible por igual, sin la participación de los dioses". ${ }^{86}$ Resalta Kurguinian que en el nuevo drama la acción dramática está constituida a la inversa:

en la libre voluntad y determinación del héroe, en una lucha consciente, consecuente y con un objetivo, la cual es sostenida por éste, porque el presente no le satisface. [...] No es la "celebración" calmada, suave, y amorosa de la existencia cotidiana en su movimiento lento, majestuoso, a veces imperceptible, sino el "tormento" analítico, impaciente y apasionado de las fuerzas de la existencia efectiva, que sólo se encuentran en la situación inicial del drama, en su antecedente inmóvil, la revelación de sus posibilidades contenidas, respecto a los cambios, destrucciones y nuevas formaciones; he aquí el énfasis del drama en sus significado común genérico.

La acción del antiguo drama griego está orientado hacia una u otra transformación de la situación inicial, sino es que a su total destrucción. ${ }^{87}$

\footnotetext{
${ }^{84}$ Kurguinian, op. cit., p. 44.

85 Ibid., p. 43.

${ }^{86}$ Iorja citado por Kurguinian, Ibid., p. 43.

87 Ibid., p. 45.
} 
Vemos entonces cómo Kurguinian resalta que el cambio en los géneros dramáticos fundamentales se definen en tanto su relación con la situación inicial planteada. Adelantándonos ya al siglo XIX, recuerda que lo trágico y la tragedia no se habían rebajado antes a las esferas de la vida prosaica, ordinaria y sin pretensiones y que el carácter trágico jamás había transcurrido en las profundas esferas psicológicas, así que se crearon nuevas formas de tipo dramático como el trágico-costumbrista, el lírico-trágico-psicológico, en incluso la comedia-psicológicatrágica, pero que mantuvieron la base genérica de lo cómico y lo trágico. Kurguinian dice:

La esencia trágica del nuevo carácter ya no se expresa ahora en el elemento lírico que prevalecía en la acción dramática. Lo trágico penetra orgánicamente en la estructura del drama, se encarna no sólo en los sentimientos y pensamientos del héroe, sino también en muchos de sus actos y acciones externamente reducidos por marcos familiares, cotidianos, muy modestos, pero que tienen un gran significado fundamental, ya que en todas las manifestaciones "insignificantes", internas y externas del héroe se hace sentir la incompatibilidad respecto a la realidad circundante. ${ }^{88}$

En este contexto llegaría Chéjov y especialmente Tío Vania para que quedara constancia de que el teatro había cambiado, obra que sería asumida como el paradigma de lo que se ha denominado como pieza y de alguna manera entendida como tragedia moderna, o drama moderno, o simplemente drama. Gorki la denominó como "una especie de arte dramático del todo nuevo. Escribió [a Chéjov]: Cuando el doctor, después de una larga pausa, habla del calorón en África, me estremecí de admiración ante su talento". ${ }^{89}$

Tío Vania, publicada en 1899, es esencialmente una extensa reconstrucción de una obra publicada una década antes, El demonio de madera. En una revisión de El demonio de madera, Chéjov redujo a los personajes de veinticuatro a nueve. También cambió el climático suicidio del personaje principal por el famoso y torpe intento de homicidio del Tío Vania. Sobre esto Kurguinian plantea una escisión a las obras de Ibsen y otros autores contemporáneos: “El atentado contra la vida de Sieriebrakov y, posteriormente, cuando el Tío Vania maquina el

${ }^{88}$ Ibid., p. 198.

${ }^{89}$ Gorki, citado por Kurguinian, Ibid., p. 206. 
suicidio, lo realiza bajo la influencia del afecto. En tanto, en sus intenciones como en sus acciones, no hay aquella irreconciliabilidad que diferenciara los actos y decisiones de otros héroes trágicos $\mathrm{y}$, en particular, de los héroes de Ostrovskii, Ibsen, Hauptman". ${ }^{90}$ Además, Chéjov alteró el original final feliz en un final más problemático en donde el Tío Vania renuncia a la idea del suicidio, direccionando otro tipo de desenlace entre las relaciones de los personajes y en la experiencia del espectador. Así, el Tío Vania hace las paces con Sieriebriakov, y acepta o asume su perdón.

Para Steiner, Chéjov está fuera del campo de consideración de lo trágico, asumimos entonces que, distinto a la condición trágica en donde la toma de conciencia del héroe lo lleva a su aniquilamiento, el Tío Vania, después de su anagnórisis y junto con los demás personajes, sigue la rutina de su vida sabiendo que el agobio será para siempre.

$\mathrm{Y}$ es que, como dice Steiner, una pieza Chejoviana no persigue fundamentalmente la representación de un conflicto o un debate: "Su propósito es exteriorizar, hacer perceptible a los sentidos, determinadas crisis de la vida interior. Los personajes se mueven en una atmósfera sensible al más leve cambio de entonación. Como si pasaran a través de un campo magnético cada una de sus palabras y cada uno de sus gestos provoca una compleja perturbación y la reagrupación de las fuerzas psicológicas". ${ }^{91}$ De hecho, Raymond Williams señala que Chéjov escribe sobre una generación que gasta toda su energía en la toma de conciencia de su propia incapacidad e impotencia:

Cuando Chéjov explora su mundo, no se encuentra ante un punto muerto -la lucha activa sin posibilidad de triunfo-, sino frente a un jaque mate, frente al reconocimiento colectivo, como

${ }^{90} \mathrm{Ibid}$. p. 208. Ostrovskii (Alexandr Nikolaievich, 1823-1886) y Hauptman (Gerhart, 1862-1946). Kurguinian revisa la obra La Tormenta, de 1860 de Ostrovskii, de la que afirma que en el fundamento de su acción dramática se encuentra ya la manifestación gradual que caracteriza al drama y la profunda variabilidad interna de la situación que, con todo, no conduce ni a la destrucción, ni a la supresión antitética como en la tragedia, ni al contraste paradójico como en la comedia, sino precisamente a la transformación profunda e interna, y hacia los cambios. $C f r$. pp. 192-193.

91 Steiner, op. cit., pp. 249. 
sucedía antes de la lucha, de que nada se puede hacer. Es el sentimiento de una generación que se pasa la noche hablando de la necesidad de la revolución, y está por ello demasiada cansada al día siguiente para resolver nada, ni siquiera sus propios problemas inmediatos. ${ }^{92}$

Para Williams, esto es totalmente una estructura de sentimiento, pues en la relación que existe entre lo que se desea, lo que se dice y lo que se hace, en esta constante contradicción colectiva, hay, a pesar de ello, "un género de heroísmo, un género ambivalente", y es este sentimiento el que Chéjov escoge para construir su teatro. ${ }^{93}$ Llama a sus obras comedias y en su tierra se consideran como tal, para nosotros, más al occidente "estas representaciones líricas y graves de la incapacidad de los seres humanos para dominar su situación o para comunicarse entre sí muestra una inefable tristeza", ${ }^{94}$ dice Steiner. Kurguinian ve en esto un estilo muy particular en el que Chéjov logra escribir una comedia llena de énfasis trágico que además conduce a los caracteres trágicos al lugar central. Tal estilo se encuentra en la capacidad de Chéjov de hacer de sus obras acciones que no tienen como eje central las circunstancias iniciales que predeterminan todo el devenir de la trama. Para Ella, el drama Chejoviano:

está construido de tal manera que en cada escena hay momentos que no tienen ninguna relación con "la situación de los Sieriebriakov"; en conjunto, estos momentos contribuyen a que las interrelaciones, que se han establecido entre Sieriebriakov y Voininskii, con la esposa de Sieriebriakov, con Astrov y Sonia y los demás, se asemejan a una telaraña que ha cubierto, no por completo, no en forma compacta, una vida verdadera, llena de sangre, muy simple y muy compleja. ${ }^{95}$

Williams lo ve de la siguiente manera:

En primer lugar no existirán personajes aislados y contrapuestos. En segundo, no habrá, en la medida de lo posible, trama alguna. Sucederán cosas, pero parecerá que suceden fuera, lo que pasa dentro del grupo serán confusiones y gestos sobre todo. En tercer lugar, el carácter contradictorio del grupo y de sus sentimientos, tiene que traslucirse en el tono general, han de coexistir la nobleza y la farsa. Esto no constituye una respuesta a la pregunta habitual de si ante tales personajes y tales situaciones hemos de reírnos o de llorar. Tal pregunta es servil, pues somos nosotros mismos quienes debemos dar la respuesta. La cuestión es, siempre, que los personajes y las situaciones pueden verse, están escritos para que se vean, desde ambas

\footnotetext{
92 Williams, op. cit., p. 124.

93 Ibid., p. 125

94 Steiner, op. cit., p. 250.

95 Kurguinian, op. cit., p. 209.
} 
perspectivas ${ }^{96}$; decidirse por una u otra de ellas es no comprender la obra [...] Está intentando [Chéjov] reflejar dramáticamente un grupo estancado, en el que la conciencia se ha interiorizado y pasa a estar, si no totalmente desarticulada, sí al menos desconectada. ${ }^{97}$

No poder percibir y asimilar la estructura genérica de los dramas de Chéjov; es decir, la reacción que como espectadores debemos asumir, se debe, sostiene Kurguinian, además de la exposición de lo prosaico o con patéticos monólogos sobre la insignificancia de la vida, a la innovación de Chéjov de incorporar situaciones inconexas, de la misma manera en que Williams señala que la conciencia de los personajes Chejovianos es desarticulada:

Con todo, el rasgo en cuestión de la estructura genérica se encuentra en plena correspondencia con la particularidad fundamental del estilo Chejoviano, caracterizado como "estilo inconexo". Tal coincidencia en las reglas del género, y del estilo, resulta muy característico. [...] Señalaremos que en el drama de fines del siglo XIX, principios del XX, el estilo juega un papel preeminente en la realización de la acción y en la determinación de sus particularidades. ${ }^{98}$

Tenemos entonces la concentración de un proceso de cambio que va desde la idea de escribir en prosa para romper las barreras que la lírica impone entre el espectador y la obra hasta teatros más pequeños para lograr representaciones más intimistas, porque los nuevos dramas presentan la realidad social pero también la forma en que la psiquis del hombre se ve afectada por tales circunstancias. Esto hizo relucir que cada hombre, por insignificante que aparente su condición, tiene en sí cargas trágicas que le son propias y que éstas pueden aparecer en los momentos más nimios de su vida y que, además, si concordamos con Kurguinian, para ser representadas exhiben el realismo de su desconexión; lo que ya es una clara separación del modelo trágico que imponía la teleología de sus destinos manifiestos como práctica poética dramática más allá de la idea de que todo lo que no tenga que ver con la tragedia lo es porque no refiere a reyes o personajes de una elitista condición social.

Esto evidentemente trajo consecuencias técnicas en la actuación pues, dice Williams,

\footnotetext{
${ }^{96}$ Recordemos aquí que obras como La gaviota llevaba el subtítulo de comedia en cuatro actos.

97 Williams, op. cit., pp. 125-126.

${ }^{98}$ Kurguinian, op. cit., p. 209.
} 
Chéjov intentó desarrollar un nuevo tipo de diálogo que "podría expresar la desintegración sin oscurecer la permanencia de una condición común", en el que lo que se dice, no es dicho esencialmente por ninguno de los personajes...

Es la paradoja final de la obra de Chéjov, los rasgos de identificación de los miembros de sus grupos dramáticos son muy superficiales, no obstante haber indicaciones constantes. Lo que resulta o puede resultar es una voz muy diferente -la voz humana dentro y más allá de la declaración directa y la autopresentación. Pero dentro de sus convenciones, y esto se acentúa normalmente en la representación, esta voz humana es intermitente y pasa inadvertida; ha de imponerse un silencio fuera de lo corriente si en realidad ha de oírse alguna vez.

Lo que Chéjov hace entonces, en efecto es inventar una forma dramática que contradice la mayoría de las convenciones existentes en la representación dramática. Para representarlo con alguna fortuna, como sabemos, Stanislavsky y Nemirovich-Danchenko tuvieron que hallar nuevos métodos de actuación y montaje: sustituir con un método interno sugestivo alterado lo que había sido presentado de modo claro y preciso. ${ }^{99}$

Para Kurguinian, la innovación por parte del Teatro del Arte de Moscú se fundamentó "precisamente en la reproducción, en toda su sutileza y precisión, de estas interrelaciones completamente nuevas, determinantes de la especificidad de la estructura de lo trágico y lo romántico, fuera de las cuales era imposible comprender la especificidad del contenido creativo de la dramaturgia de esta época". Las obras de Chéjov llevaron a Stanislavsky a procurar captar y representar lo que él describía como "verdad interior, la verdad del sentimiento y de la experiencia". ${ }^{100}$

Así es como tenemos, dice Knowles, que el surgimiento de la pieza como la más moderna de las formas del teatro vino a solucionar problema del tratamiento del realismo moderno. Según Virgilio Ariel Rivera, derivó su nombre de la antes mencionada pièce bien faite, (¿acaso por proseguirla?), cuyo término "no podía ser más adecuado para determinar el género: pieza, parte, pedazo, trozo, fragmento de algo". ${ }^{101}$ Aunque la maestra Luisa Josefina Hernández al respecto nos dice lo siguiente:

\footnotetext{
99 Williams, op. cit., p. 128

100 Macgowan y Melnitz, op. cit., p. 276.

101 Virgilio Ariel Rivera, op. cit., p. 137.
} 
A este género en México se le llamó pieza, a iniciativa de Rodolfo Usigli, pero desde finales del siglo XIX, algunos autores dramáticos percibieron que ciertas obras suyas no eran trágicas, aunque sí muy serias, por lo tanto no eran cómicas, y además eran realistas, lo cual les impedía ser fársicas. En francés empezaron a llamarse piéces, en alemán Stücke, en inglés sencillamente plays, como en ausencia de más precisa denominación. ${ }^{102}$

Pero dado que entre el momento en que se estreno El Tío Vania y los postulados de Usigli y Hernández sobre la pieza pasaron casi sesenta años debemos acentuar más la discusión no sólo sobre los elementos que dieron asidero al nacimiento de este género, sino también sobre su consolidación. Una hipótesis a demostrar propuesta por Gustavo Humberto Lizárraga, es que la pieza surge intelectualmente con Descartes y su Discurso del método "con su yo pensante y dubitativo, que no tiene más certeza que la duda, y esto sólo le trae más problemas”; el Ego dividido en: res extensa -condición de índole física- y res cogitativa -condición de índole espiritual o psíquica. ${ }^{103}$ Por su parte, Auerbach describió sintéticamente la complejidad circundante alrededor de un proceso histórico como lo es la modernidad; en primera instancia, comenta el aceleramiento del conocimiento humano en distintas esferas:

La ampliación del horizonte del hombre y el enriquecimiento en experiencias, conocimientos, ideas y posibilidades de vida, que se había iniciado ya en el siglo XVI, avanza en el siglo XIX a un ritmo cada vez más acelerado, y desde el comienzo del XX adquiere una velocidad tan vertiginosa que a cada momento se producen intentos de interpretación objetivo-sintética que inmediatamente son rechazados. El vehemente tempo de las transformaciones originaba una confusión tanto mayor cuanto que el conjunto de ellas era inabarcable: tenían lugar simultáneamente en muchos campos de la ciencia, de la técnica y de la economía, de modo que nadie, ni aquellos que desempeñaban un papel rector en estas zonas aisladas, era capaz de prever o de juzgar la situación general que se originaba en cada caso. ${ }^{104}$

Pero también señaló lo que significó en términos de desigualdad los alcances geográficos

de las transformaciones y sus repercusiones:

Tampoco las transformaciones repercutían uniformemente en todos los ámbitos, de suerte que las diferencias de nivel entre los diversos estratos de un mismo pueblo, y entre los diversos

\footnotetext{
102 Hernández, op. cit., p. 209.

${ }^{103}$ Gustavo Humberto Lizárraga Maqueo, Reflexión estética sobre la teoría de la pieza, Tesis de licenciatura, UNAM, México, 1994, pp. 93-94.

${ }^{104}$ Erich Auerbach, La media parda, en Mimesis, la representación de la realidad en la literatura occidental, trad. I. Villanueva y E. Ímaz, ed. Taurus, Madrid, 1991, pp. 518.
} 
pueblos, se fueron haciendo, si no mayores, al menos más perceptibles. La difusión de la publicidad y el hacinamiento de los hombres sobre una tierra que parecía haberse empequeñecido agudizaron la percepción de las diferencias entre las diversas condiciones de vida y las diversas concepciones, movilizaron los intereses y los modos de vida ya amenazados, ya favorecidos por los nuevos cambios, produjéronse en todos los rincones de la tierra crisis de adaptación, que fueron amontonándose y aglutinándose hasta conducir a las perturbaciones de las que todavía no nos hemos librado. ${ }^{105}$

Su mismo proceso sembró la desestabilización de grandes ideales religiosos, económicos,

morales, filosóficos, generando vacíos y llevando a consecuencias devastadoras:

Por medio de esta violenta agitación producida por el choque de las formas de vida y de las tendencias más heterogéneas, no sólo vacilaron en Europa las concepciones religiosas, filosóficas, morales y económicas que formaban parte del antiguo legado y que, a despecho de tantas otras perturbaciones anteriores, conservaban todavía una autoridad considerable gracias a su lenta transformación y adaptación; ni tampoco solamente las ideas revolucionarias del siglo XVIII y aún de la primera mitad del XIX, el racionalismo, la democracia y el liberalismo, sino incluso las nuevas fuerzas revolucionarias del socialismo, surgidas en plena época del gran capital, parecían resquebrajarse y desgarrarse, perdían su unidad y la nitidez de sus perfiles a causa de los numerosos grupos que entre sí combatían, a causa de las extrañas combinaciones de algunos grupos con ideas no socialistas, a causa de la capitulación interior de la mayoría de ellos en la Primera Guerra Mundial, y finalmente a causa de la propensión de la mayor parte de sus partidarios más radicales a pasarse al campo de sus antípodas. Por otra parte, también progresó la formación de sectas, que cristalizaban con frecuencia alrededor de grandes poetas, filósofos y sabios, la mayoría de las veces con un aspecto semicientífico, sincrético y primitivo. La tentación de confiarse a una secta - que, con una receta única, solucionaba todos los problemas, exigía solidaridad con una energía interior muy sugestiva y excluía todo lo que no se sometía y encuadraba- era tan grande que, con muchísima gente, el Fascismo no necesitó apenas violencia exterior cuando se extendió por los antiguos países civilizados de Europa, absorbiendo las pequeñas sectas.

Todavía en el siglo XIX y a principios del XX en estos países una solidaridad del pensar $\mathrm{y}$ del sentir tan claramente formulable y reconocible, que un escritor dedicado a la representación de la realidad disponía de criterios dignos de confianza para proceder a su ordenación; al menos podía reconocer en el móvil fondo contemporáneo determinadas escuelas, y podía confrontar con éstas las ideologías o las formas de vida contrarias. ${ }^{106}$

Auerbach hace esta relación del devenir del modernismo para señalar que la representación pluripersonal de la conciencia, la estratificación del tiempo, el aflojamiento de la conexión entre los sucesos externos y los cambios de puntos de vista desde donde se verifica el relato son procedimientos que afectaron a la novela realista. Procedimientos relacionados entre

\footnotetext{
${ }^{105} I d$.

${ }^{106}$ Ibid., pp. 518-519.
} 
sí, difíciles de separar, en las que se dejan ver ciertos empeños, tendencias, necesidades, tanto del escritor como del público. ${ }^{107}$ En el cuerpo de esta exposición de sucesos -en los que se deja ver el punto de fractura de los grandes relatos (el cristianismo, el marxismo, el iluminismo y el capitalismo)- también se engloba el procedimiento del efecto de realidad propuesto por Roland Barthes en la que la descripción de hechos o cosas en apariencia inútiles son las que permiten dar la sensación de lo real o de lo verosímil; ${ }^{108}$ y sobre el abuso de la descripción, Walter Benjamin ${ }^{109}$ y Lukács ${ }^{110}$ van a lamentar la desaparición o la decadencia de la narración. Éste último nos dirá que "las aventuras más extraordinarias aparecen vacías y privadas de contenido si no revelan rasgos humanos esenciales, si no expresan las cambiantes relaciones entre los hombres y los hechos del mundo exterior, de las cosas, de las fuerzas naturales y de las instituciones sociales". ${ }^{111}$ Lukács critica especialmente autores como Flaubert y Zola, en los que identifica la iniciación de su trabajo en una sociedad burguesa ya fijada y constituida, ubicándolos, a pesar de sus intenciones de darnos un cuadro crítico del régimen político y social de su tiempo, en una trágica contradicción de observadores y críticos faltos de acción. De esta manera, se convirtieron "en escritores de oficio en el sentido de la división capitalista del trabajo". ${ }^{112}$ Están alienados, como lo están todos los hombres que se cobijan bajo los parámetros del capitalismo.

Dice Hernández, citada por Knowles y refiriéndose específicamente a la pieza, que, por definición, la burguesía (pensada en términos de "pequeña burguesía") es un estado estático: "Nada sucede, dramáticamente hablando, en la vida de un miembro de la clase media. Su vida

\footnotetext{
${ }^{107}$ Ibid., pp. 515-516.

108 Ver Roland Barthes, El efecto de realidad (1968), en Lo verosímil, trad. Beatriz Dorriots, Editorial Tiempo Contemporáneo, Buenos Aires, 1972.

109 Ver Walter Benjamin, El narrador, en Para una crítica de la violencia y otros ensayos, trad. Roberto Blatt, Taurus, Madrid, 1988.

110 Ver Georg Lukács op. cit.

111 Ibid., p. 47.

112 Ibid., p. 42.
} 
normal varía de otra sólo en detalles, la diferencia entre dos individuos cualesquiera es secreta y oculta. Por lo tanto, se necesita alguna fuerza exterior o amenaza para obtener la necesaria confrontación dramática que fuerza a los personajes a externar lo privado y oculto, a abrirse al examen de este modo, a cambiar". ${ }^{113}$ En ese sentido, Michel Foucault señala que el proceso por el cual la burguesía (pensada como elite) ha llegado a ser, desde el curso del siglo XVIII, la clase políticamente dominante se debe a formas jurídicas que garantizaban un sistema de derechos en principio igualitarios, pero a su vez, en éstos había (o hay), subyacentes, mecanismos menudos, cotidianos y físicos, funcionando como un sistema de micropoderes constituidos por disciplinas que actúan como un poder múltiple, automático y anónimo que permite el control minucioso del cuerpo y que le imponen una relación de docilidad-utilidad, y en la que la vigilancia reposa sobre los mismo individuos reduciendo el aparato vigilante de un estado jerárquico. Para dicho autor, "Las Luces, que han descubierto las libertades, inventaron también las disciplinas", ${ }^{114}$ con las que los hombres vigilan a los hombres, viviendo en un estado de aparente tranquilidad, pero en las que constantemente hay un juego coercitivo que se activa al instante en que cualquier interacción entre los individuos se activa. Foucault se refiere a la disciplina como una anatomía política del detalle: "Una observación minuciosa del detalle, y a la vez una consideración política de estas pequeñas cosas, para el control y la utilización de los hombres, se abren paso a través de la época clásica, llevando consigo todo un conjunto de técnicas, todo un corpus de procedimientos y de saber, de descripciones, de recetas y de datos. Y de estas fruslerías, sin duda, ha nacido el hombre del humanismo moderno". ${ }^{115}$

Teniendo en cuenta el marco expuesto con la anterior síntesis sobre las disciplinas

\footnotetext{
${ }^{113}$ John Kenneth Knowles, "Pieza: Los frutos caídos", en Luisa Josefina Hernández: Teoría y práctica del drama, trad. de Antonio Argudín, rev. y pres. de Tomás Espinoza, UNAM, México, 1980, pp. 22-23.

${ }^{114}$ Michel Foucault, Disciplina, en Vigilar y castigar, nacimiento de la prisión (1975), trad. Aurelio Garzón del Camino, Siglo XXI Editores, México, 1996, pp. 139-230. La relación entre las disciplinas y los conflictos que surgen en la pieza será expuesta más ampliamente en el capítulo III de esta investigación.

115 Ibid., p. 145.
} 
propuestas por Foucault, Arthur Miller se ubicaría del lado de Lukács, en tanto la dignidad del hombre se enaltece en su intención y capacidad de cambiar sus circunstancias a través de la praxis humana, pues es en ella, como se había señalado, que la esencia del hombre se puede expresar concretamente. También en ese sentido, Sartre nos dejaría entrever los esfuerzos, no sólo de Flaubert o Zola, sino también del mismo Miller, para comprender un poco la posición de estos autores y sus estrategias literarias y también para describir en parte a aquellos personajes que se enmarcan en el universo del género de la pieza: "Cada hombre es lo que hace con lo que hicieron de él".

¿Qué sentimientos podemos percibir de la frase de Sartre? Esperanza y desconsuelo. Desconsuelo de sabernos envueltos en una realidad que nos predetermina dentro de lo que se ha llamado la burguesía desbocada, desconsuelo de sabernos alienados. Pero también se deja ver un halo de esperanza, si estamos en capacidad de tener conciencia de que "algo hicieron con nosotros" y que sobre esa circunstancia aún existe la posibilidad de la praxis para provocar un cisma de cambio. Pero no podemos ir tan lejos mientras en tiempos de la pieza o de la tragedia moderna estemos ante un hombre que resiente el cambio de los tiempos y no puede ser más que un pasivo observador, lleno de incertidumbres y testigo de algo que apenas intenta comprender cuando ya está en vías de ser destruido.

Nos referimos al hombre común, el cual, plantea Miller, está en capacidad de tener estatura trágica. Para Miller, el sentimiento trágico perdura en el hombre común, quien en su intención de revelarse contra aquello que lo oprime, muestra la envergadura de su dignidad, en procura de, como hombre biológico que es, no perder su humanidad, a pesar de que la situación le sea adversa. ${ }^{116}$ Para este autor hay una actualización del sentimiento trágico dentro de las

\footnotetext{
${ }^{116}$ Arthur Miller, La tragedia y el hombre común, en http://catedrahumanidadestm.blogspot.com/2009/10/latragedia-y-el-hombre-comun.html, consultado por última vez en 03/05/2012
} 
convenciones teatrales, pues hasta la pieza bien hecha el héroe clásico, a la usanza aristotélica, eran reyes o nobles que de ninguna manera encontraban correlación con el público que los veía.

La herencia de los procesos históricos que hemos descrito dejó a un hombre con una alta conciencia de su propia valía, lo que se vio reflejado en la constitución de los estados de derecho. De la misma manera, construyó el discurso de la democracia e impulsó la que sería la revolución industrial. Ésta a su vez impulsó los cimientos de la burguesía con la cual se generó la tensión entre el socialismo y el capitalismo, poco a poco este hombre con conciencia de su propia valía descubría que algo nuevo lo oprimía, un nuevo ritmo de vida que no identificaba bien para dónde iba. Los dramaturgos y los espectadores son producto de tal realidad. En estas circunstancias, señala Miller que:

la tragedia es la consecuencia de la total compulsión que tiene el hombre de evaluarse a sí mismo con justicia. [...] Sin embargo, la cualidad que nos sacude en las obras trágicas proviene del miedo subyacente que tenemos de ser desplazados, del desastre que significa que seamos arrancados de la imagen que hemos elegido para representarnos qué y quiénes somos en este mundo. Entre nosotros, hoy en día este temor es tan fuerte, o tal vez más fuerte de lo que fue siempre. En realidad, es el hombre común quien conoce mejor que nadie este temor.[...] Los griegos podían elevarse y probar el origen divino de sus costumbres y descender para confirmar si sus leyes son justas. Y Job podía enfrentar a Dios con enojo en reclamo de sus derechos y terminar sometido a sus designios. Pero, en algún momento preciso estos personajes someten todo a la crítica, nada se acepta y esta manera de forzar y de rasgar el cosmos, el mismo hecho de hacerlo le confiere "estatura", estatura trágica al personaje, cosa que generalmente, y de manera espúrea es como se califica a los personajes de la realeza o de alta condición social. El más común de los hombres puede alcanzar dicha estatura, siempre y cuando tenga el deseo de cuestionarse todo lo que posee en esta batalla para lograr el lugar que le corresponde en este mundo. ${ }^{117}$

Determinar esto es importante, porque la materia prima de la pieza, a la manera en que la plantea Rivera, es el hombre, pues en su raíz está "la necesidad del ser humano de conocerse a sí mismo, al establecer clara relación con el medio circundante total -el conocimiento de su pasado, su posición en el presente, su enfrentamiento con el futuro". ${ }^{118}$ Por otro lado, una de las críticas de Hernández a Aristóteles es que no tomó en cuenta "que una parte exquisita de la

\footnotetext{
${ }^{117} I d$.

${ }^{118}$ Rivera, op. cit., p. 138.
} 
creatividad de un dramaturgo consistiera en lograr un nuevo género a partir del carácter y de las circunstancias que tornean la conducta de unos personajes". ${ }^{119}$ Este particular carácter y circunstancias del personaje descrito por Miller, y que a su vez es el mismo de Hernández, proyecta una nueva concepción de destino que bien podemos advertir señalado por Auerbach al decirnos que muchos escritores ven en los sucesos menudos, cotidiano e insignificantes la capacidad para proporcionar algo decisivo con respecto al tema, concediendo menos importancia a "los golpes espectaculares del destino", y apuntando que "en lo seleccionado arbitrariamente del transcurso de la vida, en cualquier momento de ella, está contenida toda la sustancia del destino y éste, por lo mismo, puede representarla”. ${ }^{120}$ Bentley, por su lado, señalará que "Freud escribió un libro revelador titulado Psicopatología de la vida cotidiana, donde demostraba que ciertas formulaciones verbales carentes en apariencia de contenido encubrían en realidad un cúmulo de significaciones. Bajo una trivial superficie intelectual se hallaba al acecho poderosos conflictos emocionales. ¿Acaso no podemos, en un sentido análogo, hablar del drama de la vida cotidiana, aún allí donde el drama parece estar ausente por completo?"121

Sobre la base de lo anteriormente planteado suscribimos, como se ha dicho antes, que una obra como Tío Vania, o El largo viaje de un día hacia la noche de Eugene O'Neill, o Muerte de un viajante del mismo Arthur Miller, e incluso Un tranvía llamado deseo de Tennesse Williams, se enmarcan dentro de la práctica dramática que denominamos pieza. El Tío Vania es testigo de que su fuerza de trabajo se direcciona en vano; Willy Loman es incapaz de mantener unida a su familia, disfunción que se da a causa de sus errores del pasado; los Tyron son incapaces de pasar un día de verano juntos porque se atribuyen sus frustraciones los unos a los otros. Son familias

\footnotetext{
119 Hernández, op. cit., p. 205-206.

120 Auerbach, op. cit., p. 516.

121 Bentley, op. cit., p. 17.
} 
comunes y corrientes, cercanas a la vida del espectador que al verlos sufre una catarsis por identificación. Tal identificación es presuntamente el nuevo puente entre el hombre moderno y su sociedad, convención y estructura de sentimiento en plena comunicación en las que podríamos entrever los sentimientos trágicos contemporáneos.

Pero si hasta aquí nos hemos propuesto hacer un planteamiento de las raíces humanas, sociales y estéticas de la pieza, esas descripciones son en vano si no adentramos una definición de la pieza de acuerdo con sus elementos estructurales, que a su vez implican la labor de unificar los términos que se han usado para describir a nuestro género de estudio. 


\section{CAPÍTULO II}

\section{ELEMENTOS ESTRUCTURALES DE LA PIEZA: DIVERGENCIAS Y ENCUENTROS}

Para dar una perspectiva general de lo que hablaremos, señalemos lo siguiente sobre los elementos estructurales de la teoría de los siete géneros de Luisa Josefina Hernández a partir de sus seguidores o alumnos. Para Juan Tovar, dichos géneros se determinan por su enfoque, su concepción, su función y su dinámica. Así, Tovar dice que el enfoque de la pieza es realista a diferencia, por ejemplo, del melodrama que es simbólico; su concepción es formal, de manera distinta a la tragedia, que en su concepción es temática; su función es la catarsis por identificación, por compasión, lo que la diferencia de la farsa, en donde su función es la catarsis como un choque emocional sin sentido evidente; y su dinámica está en el movimiento interno (toma de conciencia o anagnórisis) y estatismo interno del personaje, quien tiene defectos y cualidades en igual proporción, a diferencia de la comedia, cuyos personajes representan cualidades que con la sumatoria de un vicio cómico tienen como consecuencia un castigo, que por lo común es ridículo y que puede llevar a la reforma. ${ }^{122}$ Las anteriores características son presentadas en Tovar en un cuadro explicativo, pero observemos que dentro de lo que define como "dinámica" existen dos componentes que otros autores señalan por separado: el personaje (sus características) y la trayectoria (del personaje).

${ }^{122}$ Juan Tovar, Doble vista, Editorial El Milagro, México, 2006, pp. 58-59. 
Por su parte, Alatorre señala los mismos componentes que Tovar, pero suma a éstos el tono, que en el caso de la pieza es neutro o cotidiano con lo que se puede diferenciar de la tragicomedia cuyo tono es serio-cómico; incorpora el hecho de que la pieza contiene un material probable al igual que la tragedia o la comedia y distinto a la obra didáctica, que contiene material posible; e introduce la diferencia que hicimos anteriormente en que los personajes se dividen en complejos (como en la pieza) y simples (como los personajes del melodrama quienes son portadores de valores ya sean positivos o negativos); y por último, sobre la idea de Tovar de una dinámica de movimiento interno a la hora de la anagnórisis, Alatorre va a plantear dos consecuencias de tal colisión dramática, por un lado la capacidad del personaje de cambiar su situación expuesta en movimientos externos o, a pesar de la toma de conciencia de su situación, es incapaz de modificar tal situación y debe continuar igual. ${ }^{123}$

Por su lado, Virgilio Ariel Rivera es mucho más abarcador e incluye, palabras más, palabras menos, lo dicho por Tovar y Alatorre, pero además apuesta a proponer nuevos elementos o términos a tener en cuenta. Así, nos dice que la pieza parte de la necesidad del hombre de conocerse a sí mismo; reconoce valores tanto éticos, sociales y personales; asume la complejidad de la psique humana, el desajuste del individuo con su medio social; su sentido es dar una visión objetiva de la psicología social; su función artística es concientizar integralmente al espectador en los aspectos moral, psicológico, humano, etc.; el protagonista es complejo, desajustado con su medio, en crisis común con uno, varios o muchos problemas de orden psicológico; los esquemas básicos son que el protagonista se ubica o no con su medio y consigo mismo; el conflicto puede ser de todos los órdenes; que maneja emociones controlables e incontrolables por igual; los otros personajes son complejos o simples por igual; la víctima,

${ }^{123}$ Claudia Cecilia Alatorre, "Los géneros dramáticos”, en Análisis del drama, 3a. ed., Escenología, México, 1999, p.50 
cuando hay, regularmente es el protagonista; el tono es cotidiano, natural, mesurado; los sucesos son los más comunes posibles; la toma de conciencia es de orden individual, la mitad de las veces se da en el protagonista y en la otra mitad no se da, y en el espectador puede tardar horas y días en darse; el final es siempre desafortunado; el espectador se identifica (desde lejos y de muy mala gana) con el protagonista; contiene siempre elementos de estilo naturalista. ${ }^{124}$

Consuelo Garrido utiliza el mismo sistema de Tovar al hacer un recuadro: concepción, tono, trayectoria del personaje, composición del carácter, efecto del público. ${ }^{125}$ Anteriormente, también señalamos que Knowles, en la tesis dirigida por Hernández, dice que los elementos comunes a todo drama son el personaje, la trayectoria de la figura dramática en la obra, el tono, la concepción y la relación que existe entre el público y la obra. Asimismo, Hernández dirigió la tesis de Humberto Lizárraga, realizada en 1994, que tituló Reflexión estética sobre la teoría de la pieza, en la que aborda el género desde una perspectiva menos preceptiva que los anteriores autores citados, aunque señala que algunos elementos característicos, constitutivos y estructurales de la pieza son la anécdota, su relación con lo simbólico, su relación con la realidad y el lenguaje que se maneja dentro de la pieza; también describe su tono, su concepción y, especialmente, su personaje. ${ }^{126}$

Con este acercamiento general, advirtamos que abordaremos este tema basados en la estructura propuesta por Luisa Josefina Hernández en su texto ya citado La pieza como género dramático, El jardín de los cerezos de Chéjov. Sin embargo, se incorporarán aquellos apuntes que otros autores han hecho sobre el tema y que a veces son catalogados como elementos estructuradores o simplemente como elementos que se tienen en cuenta para señalar

\footnotetext{
${ }^{124}$ Virgilio Ariel Rivera, La composición dramática, Editorial Escenología, México, 2004, p.133.

${ }^{125}$ Consuelo Garrido, No ser héroes, apuntes en torno a la pieza en algunas clases de teoría dramática de Luisa Josefina Hernández, en Claudia Gidi y Jacqueline Bixler (coords.), Las mujeres y la dramaturgia mexicana del sigo XX, ed. El Milagro, México, 2011, pp.102-103

${ }^{126}$ Gustavo Humberto Lizárraga Maqueo, Reflexión estética sobre la teoría de la pieza, Tesis de licenciatura, UNAM, México, 1994.
} 
características de la pieza, para asimismo señalar las diferencias o puntos en común que tienen estos autores.

\subsection{Concepción: tema, anécdota y estructura}

El primer concepto que se hace necesario definir es el de concepción. Entre los autores mencionados hay un acuerdo en señalar lo que refiere a concepción formal y es por eso que en el momento de hablar sobre esta noción suelen extenderse sobre a qué refiere "lo formal" dentro de la pieza. Rivera no habla directamente del concepto de concepción y Tovar tampoco ayuda mucho en su definición pues nos dice que "esto último [la concepción temática en la tragedia] quiere decir que al poeta le preocupa, más que la acción en sí, el sentido de la acción, su significado". ${ }^{127}$ Así, Tovar sólo dice que además de que la concepción para la pieza es formal, para la tragedia es temática, para la comedia, el melodrama y la tragicomedia es anecdótica, para la obra didáctica es lógica y para la farsa dependerá del género que esté en el trasfondo (recordemos que Tovar dice que, según Hernández, la farsa es un género “camaleónico que opera sobre los otros").

En el primer capítulo de su libro, Alatorre empieza dando una mirada general sobre cómo analizar el drama, sin embargo, aunque su sistema es el de la teoría de los siete géneros, no refiere en tal capítulo sobre la idea de concepción. ${ }^{128}$ Sí lo hará en la descripción de cada género, pero no lo hace señalando a qué alude Hernández cuando habla de concepción, sino a al complemento que le refiere con cada género (si es temático, anecdótico, lógico, dependiendo de...). Sobre la pieza dice que "es un género de muy poca acción, o sea, su anécdota va a

\footnotetext{
127 Tovar, op. cit., p. 61.

${ }^{128}$ Véase Alatorre, op. cit., pp. 13-30.
} 
mostrar un conflicto cotidiano que, a pesar de ser mínimo y frecuente, el personaje extrae de él conclusiones importantes que transformarán su vida". ${ }^{129}$ Alatorre anota un tópico que autores como Lizárraga y Knowles también exponen, el de la relación de la pieza con la burguesía. Para esta autora, el centro temático de la pieza es la demostración de la progresiva rigidización e inmovilidad de la burguesía, que como clase se ha rezagado históricamente y se condena a la extinción; la decadencia de la burguesía fue necesaria para que sus valores determinaran el sentido del movimiento de la pieza y es por tal que sus personajes dan excesivo valor a la seguridad y el devenir histórico apacible. Lo cual resulta en que, dice Alatorre, la pieza reproduzca el vivir cotidiano del burgués, dado a la impotencia de los cambios venidos desde otras clases de la sociedad; impotencia que le vienen de sus prejuicios de clase, el ocio, la comodidad, la seguridad, las buenas maneras. De esta improductividad y de su empobrecimiento se va a desprender el carácter del personaje. "Entonces, a pesar de contener muy poca acción, la pieza prefiere resaltar la importancia de la acción interna de los personajes, compensándose de esta manera que la acción externa sea mínima; este fenómeno concreto es el que recibe el nombre de concepción formal'”. ${ }^{130}$

Para Knowles, la noción de concepción es quizá la más difícil de explicar y registra lo “que significa” para Hernández, tomándolo de conversaciones que tuvo con ella en 1966:

...[es] el mecanismo empleado por el autor para 'ajustar' alguna acción que empieza a perturbar la tranquilidad doméstica del mundo burgués, tema principal de la pieza. En una forma tajante, Luisa Josefina Hernández afirma que por definición la burguesía es un estado estático. Nada sucede, dramáticamente hablando, en la vida de un miembro de la clase media. Su vida normal varía de otra sólo en detalles, la diferencia entre dos individuos cualesquiera es secreta y oculta. Por lo tanto, se necesita alguna fuerza exterior o amenaza para obtener la necesaria confrontación dramática que fuerce a los personajes a externar lo privado y lo oculto, a abrirse al examen y de este modo, a cambiar. ${ }^{131}$

\footnotetext{
${ }^{129}$ Ibid., pp. 52-53.

${ }^{130} \mathrm{Id}$.

${ }^{131}$ John Kenneth Knowles, "Pieza: Los frutos caídos", en Luisa Josefina Hernández: Teoría y práctica del drama, trad. de Antonio Argudín, rev. y pres. de Tomás Espinoza, UNAM, México, 1980, pp.22-23
} 
Seguidamente, Knowles ejemplifica con la obra Los frutos caídos y no vuelve a tocar la noción de concepción. Por su lado, Lizárraga habla de la concepción en al apartado al que tituló La estructura formal. En él, presta atención al detalle de que Chéjov llamó a sus obras "costumbristas", puesto que su peso es lo que constituye y delimita lo cotidiano. Estos hábitos y formas de estar (desde lavarse los dientes, caminar, hasta la forma de respirar, etc.) son adquiridos por imitación e inconscientemente pero a su vez son el escenario que permiten al hombre vivir en ilusiones y proyectos. Además propone que:

Hablar de pieza como una obra de concepción formal implica varias cosas: 1) Es una estructura que puede ir de uno a cinco actos. 2) Tiene un esquema estructural que consta de tres partes básicas: planteamiento del problema, desarrollo del mismo y, por último, un desenlace. 3) O formulado de otra manera, se trata de una obra que presenta o plantea un problema de acción, un clímax de ese problema y, por último, un desenlace. ${ }^{132}$

Aunque el punto uno y el dos pareciera que exponen lo mismo, Lizárraga aprecia las diferencias porque, al advertir sobre el clímax, Hernández señala lo siguiente: "lleva el conflicto al mayor extremo que alcanzará en la obra, lo cual es una etapa anterior a la solución, que puede ser otro acto, en la mayor parte de los casos". ${ }^{133} \mathrm{Al}$ hablar de clímax, plantea, se hace referencia al momento de mayor intensidad en la acción más allá de la mitad de la obra, del que dependerá la solución de una determinada acción planteada y es el momento de mayor conflicto. Como consecuencia lógica, del clímax viene el desenlace, conclusión lógica de la obra, dadas las situaciones humanas cotidianas de frustración y compensación planteados en la pieza, la cual expone un retorno a la realidad a la que se está acostumbrado, a la rutina diaria. Pero, al final de la obra, hay una variación de los personajes entre su dignidad y respecto a su propia vida, así "la pieza pone en juego de los personajes su capacidad de autoestima". Otra forma de percibir la

\footnotetext{
${ }^{132}$ Lizárraga, op. cit., pp. 84-85.

${ }^{133}$ Ibid., p. 85.
} 
concepción formal, continuando con Lizárraga, es su estrecha relación con un tema único: la aceptación de la vida como un continuo ir y venir de frustración y compensación, demarcado sólo por la muerte, como diría Heidegger, pues ésta marca los límites de nuestra cotidianidad. Dicho tema único, se desarrolla de una forma variable y cuenta la añoranza de vida de las diferentes sociedades y personas en distintos momentos de la relación histórica que como anhelo y universo de la ilusión siempre va a conducir al fracaso. ${ }^{134}$

Sostenemos que, sin definir a qué refiere Hernández con concepción, los anteriores autores no establecen la claridad necesaria para entender a qué se están refiriendo con concepción formal. Las definiciones, aludidas directa o indirectamente, señalan cuestiones divergentes y sólo confluyen cuando exponen el material temático con el que se construye la pieza (la burguesía, las costumbres y la vida cotidiana, la frustración). Consuelo Garrido, en cambio, sí establece una relación entre los dos conceptos-concepción y formal-cuando brevemente menciona que "la concepción, según Luisa Josefina Hernández, es el criterio que el autor toma en cuenta para presentar el material dramático y que da por resultado la estructura". ${ }^{135}$ Intuyo que, para esta autora, la noción de concepción puede llegara responder preguntas como:

¿Cómo fue la concepción de la obra? ¿Se escribió a partir de un tema (es decir, va de lo general a lo particular), o más bien el autor se apegó, principalmente, a desplegar su material en un molde dramático aristotélico (presentación desarrollo, nudo y desenlace)? ¿Quizá prefirió dejarse llevar por una trama anecdótica o se inclinó por la exposición del material dramático en una secuencia lógica didáctica (como en las obras de Brecht, que nos llevan a tomar una posición ante lo que vemos)? ${ }^{136}$

De esta manera podemos acercarnos a lo que Hernández, quizá, realmente quería decir con concepción. Dicha autora no estaba cómoda con la idea de que toda obra que no fuera

\footnotetext{
134 Véase pp. 84-86.

135 Garrido, op. cit., p. 111.

136 Ibid., p. 105.
} 
vaciable en el molde aristotélico resultara siendo una obra bastarda, y que por ello fuese considerada inferior. No es difícil suscribir su postura, ya citada anteriormente, de que Aristóteles no tomó en cuenta la posibilidad de que existieran otros géneros, que un material dramático lograra otras opciones ni que un dramaturgo pudiera lograr un nuevo género a partir del carácter y de las circunstancias que tornean la conducta de unos personajes. Si se dice que la tragedia tiene una concepción temática, se está afirmando que "la estructura que presenta la obra finalizada está regida por el tema, o sea, la tragedia es un género de concepción temática. Entiéndase por concepción el criterio para estructurar". ${ }^{137}$ El ejemplo que usa Hernández para tal acercamiento es Edipo rey, pues si se acuerda en que su tema es la soberbia, "nos preparamos para contemplar la trayectoria de un hombre que por soberbia piensa que puede manipular todas las acciones de su vida, para llevarlas al fin que le parece correcto y, en consecuencia, vemos cómo, en vez de evitar situaciones que él conoce, cae directamente en ellas". ${ }^{138}$ Para Hernández, pensar en esta trayectoria marcada por la idea de soberbia, exige un ordenamiento de sucesos que determinan la estructura dramática, entendida ésta como un acomodamiento del material dramático. Con esto, Hernández afirma que la pieza es de concepción formal porque:

...es una masa informe de elementos cotidianos de los que sobresalen factores como la pobreza, la clase social, el trabajo, la repugnancia hacia el trabajo, la nostalgia, los arrepentimientos, la imposibilidad de mantener un estado de cosas. Pero el tema o los temas que se dejan ver no podrían marcar un verdadero dibujo estructural, son demasiado amplios y no se concentran en acciones mayores, sino en análisis de carácter y situaciones, lo cual nos encamina a decir que tienen acciones interiores y no exteriores. ¿De qué tratan estas obras? De la vida, sencillamente, una vida que no es perfecta pero es continua.

Esta situación es en sí una petición de forma, de una forma preliminar al hecho de escribir, una forma conocida y asimilada por el autor como un elemento cultural previo. En otras palabras un molde, para volver tangible, representable y estético el material que antes de esto fue una suma desordenada de conocimientos, experiencias y opiniones. ¿De dónde tomar esta

\footnotetext{
${ }^{137}$ Hernández Luisa Josefina, La pieza como género dramático: el jardín de los cerezos, de Chéjov, en Los frutos de Luisa Josefina Hernández, aproximaciones y escritos de teoría dramática, Felipe Reyes Palacios y Edith Negrín editores, UNAM, México, 2011, p. 208.

${ }^{138}$ Ibid., pp. 207-208.
} 
forma?

Sorprendentemente, de Aristóteles, quien ofrece un conjunto de reglas para fundamentar una estética dramática, construida a partir de una obra que es para él perfecta: Edipo rey de Sófocles. No debemos olvidar que si en verdad la tragedia tiene una concepción temática y no formal que Aristóteles no advierte, el mero hecho de proponer la obra de Edipo rey como modelo, resulta inadecuado. Pero lo hace y la proposición perdura y se reproduce. [...]

Así encontramos a Chéjov creando un género de concepción formal y observamos la utilización de una forma trágica tradicional para lograr un material que no es trágico. ${ }^{139}$

Parte del proyecto que vio nacer a la pieza como género tiene que ver con esta formulación de Hernández. Reconoce que el genio de Chéjov, acorde no a una moda del momento sino a "la necesidad de expresar ciertos asuntos", configuró al género de la pieza al entregarnos obras en las que el personaje central sucumbe ante su decisión de arrastrar el mismo error a lo largo de su vida con gran humillación, vaciado en una concepción formal clásica (aristotélica), en la que, como también señaló Lizárraga, encontramos tanto las unidades de espacio, tiempo y acción como el movimiento en tres pasos de presentación, desarrollo y crisis, y solución. Para Hernández

...no es posible enjuiciar las obras de teatro como si el autor no las conociera antes de escribirlas, o sea, ignorar que los personajes tienen una trayectoria, y que no es lo mismo darle vida a un personaje dirigido a su muerte, con todas sus profundas motivaciones y pasiones, que crear un personaje que se encamina hacia la continuidad de su vida con un conocimiento más o menos frustrante de un futuro que se revelará ante nuestros ojos. Esta diferencia está basada no sólo en la trayectoria sino en el carácter del personaje y debería ser suficiente para lograr un elemento distintivo muy fuerte. ${ }^{140}$

Se deja entrever que la concepción aparece como el criterio por el que el escritor se inclina cuando confronta el material que va a moldear y la estructura que piensa utilizar. Pensamos que es una petición de principio difícil de sostener aceptar que el autor tiene dominio total de la obra que se dispone a escribir y que por la misma vía nos lleve a la certeza de señalar

\footnotetext{
139 Ibid., pp. 208-209.

${ }^{140}$ Ibid., pp. 209-210.
} 
qué tipo de concepción tiene un drama. ${ }^{141}$ Esto hace que nos preguntemos dónde está la noción de concepción: ¿en una postura previa a la obra, es decir, está en el autor o está en la obra? Si decimos que concepción es el criterio que el autor usa para estructurar, esa será siempre una afirmación que no se podrá comprobar sólo con la obra, en especial si generalmente está sola ante el lector o el espectador. Sin embargo, sí es posible asumir que tal o cual concepción es congruente con la obra, no entendiéndola a modo de apuesta o adivinanza sobre qué pensaba o no el autor, sino entendida en el devenir del desarrollo de la obra a medida que se analiza su estructura y la relación que tiene con el material dramático que ha moldeado. El concepto de concepción conlleva el de mimesis, cómo y qué se imita; ya diría Aristóteles que la manera de imitar es fundamental para definir las distintas artes, no es difícil suponer que asimismo se puede entender al interior de cada una las mismas artes; de esta manera, el estagirita dirá que el tipo de representación dramática marca diferencias entre la tragedia y la comedia (la última mostrando a los hombres peores de lo que son y la tragedia superiores a la realidad). ${ }^{142} \mathrm{La}$ concepción, entonces, se podrá apreciar, no como el criterio para estructurar, sino el posible criterio con que se terminó de estructurar la obra, es decir, un criterio que se ha podido construir después de que se ha elaborado un análisis que permita identificar el tipo de mímesis que conlleva.

Y para el caso de la pieza, tal mímesis no sólo está atravesada por la trayectoria del personaje, sino por el carácter del personaje y la postura ante sus circunstancias, la cual, al final de la obra, nos permitirá presentir de manera inminente cuál será el futuro de ese personaje (además, porque hay un futuro en el personaje de la pieza, distinto al personaje de la tragedia). La diferencia no es mínima si se tiene en cuenta la confusión que se ha generado alrededor de la

\footnotetext{
${ }^{141}$ Recordemos que el Tío Vania, de Chéjov, fue una reescritura del Demonio de madera.

${ }^{142}$ Aristóteles, Poética, trad. del griego de Francisco de P. Samaranch, Aguilar, Madrid, 1966, p. 28.
} 
noción y se sostiene cuando hemos visto que quienes han intentado hablar de la concepción se extienden sobre el desarrollo temático y no sobre el poder estético que tiene el tema -que se ha identificado- sobre la estructura (recordemos la relación entre un tema único y la pieza que Lizárraga observaba).

Es allí donde Hernández es sumamente clara, especialmente cuando habla de tragedia y para el caso de la pieza. Cuando asume que una obra finalizada está regida por el tema y que esto define su trayectoria, estructurándola, encontramos que las posibilidades de estructuración son infinitas. Es el caso de la tragedia, que para ella será multiforme y por lo tanto de concepción temática. Es decir, el tema se alza como un elemento dominante a la hora de diferenciar el género. Mientras que en la pieza, la concepción formal se halla cuando la obra refleja, además de cierto realismo, una dinámica propia cercana a la que lleva la vida misma conciencia desarticulada, prosaica, disociación de las causalidades del cotidiano, sino vital en las minucias- que impone su forma estéticamente (con las debidas selecciones pertinentes para construir la obra). No es lo mismo concebir un obra dramática calculando los grandes golpes del destino que estructurarán, que escribir proveyendo a las arbitrariedades del devenir de la vida la médula y sustancia del destino. En esta perspectiva, no deja de ser sorprendente cómo coinciden Hernández y Kurguinian, cuando la autora rusa afirma que la innovación de Chéjov se manifiesta, ante todo, en lo inconexo de la situaciones con respecto a un postulado inicial, una forma de antítesis de los principios trágicos en la que las situaciones a través de toda la obra se relacionan orgánicamente con una premisa que desde el principio ha quedado clara.

Si el autor no partió de escribir sobre el peso de tales situaciones inconexas en la vida de un personaje, no será relevante si señalamos si lo hizo o no a conciencia concibiendo una obra formal, porque el sentir de época, de acuerdo con ese gran tema que es la vida cotidiana, lo encauzó a estructurar una obra que refleja a un personaje incrustado en cierta comodidad, que 
poco a poco revelará su malestar en el clímax de la obra para después llevarse consigo la conciencia de que las condiciones de vida que sobrelleva son irremediablemente tal y como las conoce. La forma de la vida cotidiana aparece como imperativo dominante en la pieza más allá que en cualquier otro género, situación que, ya nos dijo Hernández, es en sí una petición de forma que antecede al hecho de escribir, que ha sido absorbida y vive como imaginario e ideología en el escritor.

Por último, la concepción formal como elemento estructurador relevante alude, como se ha venido observando, a la anécdota. Esta noción no aparece desarrollada por Luisa Josefina Hernández, ni tampoco entre la mayoría de los estudiosos de la teoría de los siete géneros, sin embargo hacemos la salvedad de enunciarla como un punto para tener en cuenta en la definición de la pieza. Alatorre, Tovar, Rivera, Knowles comentan que la comedia, el melodrama y la tragicomedia son de concepción anecdótica. Esto quiere decir que la estructura de la obra concentra la responsabilidad de una demostración de causa y efecto, que va desde los orígenes del conflictos, pasando por el desarrollo del conflicto en sí, hasta llegar a su solución. Lizárraga dirá que la anécdota es la acción llevada a cabo por uno o varios personajes a lo largo de una obra, pero para el caso de la pieza es sumamente sencilla, pues la complejidad de la pieza no está en la historia, sino en el carácter de los personajes que la viven.

Si hay una equivalencia entre la anécdota y la fábula aristotélica, encontraremos que éste es uno de los quiebres que Hernández señala en la obra de Chéjov con respecto a los preceptos de la Poética. Aristóteles diría que la fábula es la acción, el entramado de los hechos; así, la tragedia no imita a los hombres, sino una acción; por lo tanto, sin acción no puede haber tragedia, mientras que sí la puede haber sin caracteres; también diría que la fábula es el principio y "como el alma de la tragedia"; así que en una tragedia la principal fuente de placer para el alma del espectador está en las partes de la fábula: las peripecias y los 
reconocimientos. ${ }^{143} \mathrm{Al}$ contrario de esto, la pieza no nos entrega grandes peripecias y el reconocimiento suele darse en el interior del personaje, quien descubre cosas de sí mismo. Si la pieza es el vaciado de gran material psicológico en el que las acciones desencadena conflictos internos dentro de los personaje, la anécdota en sí de una pieza puede llegar a ser muy sencilla y su definición está alejada de la espectacularidad. La concepción formal, entonces, se identificará también en el desarrollo de un material dramático cuya anécdota es superficial y bastante simple, puesto que el imperativo del cotidiano impone su estética y estructura, y se revela cobijada bajo el manto de un tema único y sus distintas visiones: la vida.

\subsection{Relación con la realidad: enfoque, material, tono}

Hay un consenso entre los estudiosos de la pieza de afirmar que, de los siete géneros, es el más realista. Esquemáticamente, Alatorre dice que el tono de la pieza es neutro o cotidiano, que contiene material probable y que pertenece al realismo. En estos tres puntos, directa o indirectamente, también coinciden Tovar, Garrido, Knowles, Lizárraga y Rivera. Lo común de estos tres elementos es que están directamente referenciados a la realidad, referencia que no deja de plantearse como un problema, por lo cual, hay varias consideraciones que se deben tener en cuenta, como las que anticipaba Román Jakobson al advertir que cuando nos refiramos a realismo hay que andarse con cuidado, puesto que es usual que la palabra sea usada como un comodín con distintos significados. Entre ellos, tener en cuenta que con facilidad confundimos como realista la obra propuesta como verosímil por el autor, con la obra percibida como verosímil por el receptor, o la que posee los rasgos de la escuela artística creada en el siglo XIX

${ }^{143}$ Ibid., pp. 39-41. 
(también incluye la combinación entre éstas). ${ }^{144}$ Expongamos, entonces, qué dicen los distintos autores sobre la pieza y el realismo para poder sacar una conclusión al respecto.

Knowles dice que con la llegada del realismo, el melodrama no permitía ya que el dramaturgo expresara su visión, pues no funciona; por lo tanto los autores buscaron nuevas formas a través de las cuales pudiera afirmar su visión de la realidad. Según este autor, los dramaturgos lo hicieron a través de la tragedia, que era la forma realista más tradicional, alterando la composición de las figuras dramáticas. Dice que Hernández siente que la modificación de la clásica figura trágica tiene precedentes anteriores al realismo, pero al cual éste regresó para sustentar el interés de la actitud romántica hacia los elementos folclóricos y populares vistos como material susceptible a consideraciones y tratamientos literarios. El individuo, como valor central independiente de su situación, mereció tratamiento dramático a través del burgués, conduciendo y encontrando así el género realista que pedían los tiempos, consistente con su sujeto: el hombre común. Knowles afirma que el análisis de un personaje parte de un marco de referencia, un nivel objetivo desde el cual pueda juzgarse. La llave para este juzgamiento es el sentido común con el cual podamos responder a preguntas como ¿es verosímil el personaje? ¿se asemeja a nuestros allegados? Si podemos afirmar, sin duda, que esa persona pueda existir, entonces la forma de la cual proviene el personaje es una forma realista. Precisar su verosimilitud determina el éxito del autor en crear personajes que posean un equilibrio dinámico entre sus características positivas o negativas; si encontramos que su caracterización desvela una naturaleza contradictoria, entonces no es un personaje plano, es redondo, real. ${ }^{145}$

\footnotetext{
${ }^{144}$ Véase Roman Jakobson, Sobre el realismo artístico, en Teoría de la Literatura de los formalistas rusos, comp. Tzvetan Todorov, trad. Ana María Nethol, Edit. Siglo XXI, México, 1978, pp. 71-79.

145 Knowles, op. cit., pp. 19-21.
} 
Luisa Josefina Hernández considera que la pieza y la tragedia poseen el mismo realismo, pues pretenden mostrar en el foro una equivalencia con la realidad, en donde encontramos recursos como el monólogo interior (equivalente del pensamiento), o la presencia de símbolos cuya función es subrayar la realidad y, además, darle aliento poético. Esto sugiere que el realismo tiene grados, así lleve el usual proceso de síntesis y selección; los cuales, ante la complejidad del cuadro que ofrece la realidad, conducen a la delimitación de elementos reales que se incluyen en un espacio determinado: el texto mismo. El problema que trae consigo el hecho de que la tragedia clásica griega se ubica en un espacio casi mágico, situado entre la historia y el mito, se supera si se entiende la idea de que el realismo es un estilo que nunca puede ser total, por falta de espacio intelectual, emotivo y factual (así como los otros estilos: romanticismo, naturalismo, etc.). El autor trágico griego selecciona y sintetiza los hechos que temáticamente se refieren a la instancia clave en que se lleva al hombre a su última realidad, la de su destrucción o la de su apoteosis. La elección de una anécdota para hablar, por ejemplo, de la soberbia, puede ser una u otra, y mejor si es de preferencia familiar al público, pero su apego a la realidad está en la descripción de las pasiones, las que irreductiblemente son universales. Así, por más realista que sea, el teatro siempre es ficción. En ese aspecto, las coyunturas sociales definen qué es trágico y que no. Lo que resulta en que se consideran insignificantes las acciones que surgen de personas definidas también como insignificantes, aquellas que no alcanzan la categoría de personajes trágicos por no destacarse como poderosos (reyes, héroes, dioses vs esclavos, vasallos, soldados). Tales distancias sociales las vemos desaparecer cuando la sociedad evoluciona en general. Admiramos cómo poco a poco Chéjov lleva a perfilar personajes trágicos entre pequeños y medianos propietarios del campo o la ciudad. Hombres que dan la tónica del siglo: van al dinero, vienen de él, lo cual no los convierte en personajes simples, inaceptable en una obra realista. El dramaturgo ruso nos muestra sus fantasías, sus 
caprichos, sus manías de ser humano adinerado, porque el dinero condiciona la conducta; y muestra lo que pierde quien pierde dinero: proyectos, comodidades, seguridad y la satisfacción de las pasiones. ${ }^{146}$

Para Alatorre, el drama debe ser reconocido con base a sus rasgos fundamentales, identificar que representa un choque entre los intereses y afanes del ser humano y sus circunstancias históricas. Igual que Hernández, resalta que la creación artística no pretende plasmar totalidades del proceso vital, la cual sólo se puede alcanzar de manera relativa con la producción intelectual. Tal relatividad presenta la paradoja de que, por un lado, no se puede mostrar como una apariencia y, por el otro lado, tampoco puede tener la exagerada pretensión de absoluto; la plasmación artística consiste en que esta imagen completa y relativa ha de causar la impresión de la vida, incluso de manera más luminosa e intensa que la vida misma de la realidad objetiva. Según esta autora, el pensamiento humano cuenta con dos posibilidades lógicas si acordamos que la realidad objetiva ofrece un material cuantitativa y cualitativamente infinito, inabarcable: generalizar o particularizar. Cuan congruente sea la selección de elementos que provengan de la realidad objetiva más se obtendrá una sólida base para la unidad de acción que necesita el drama. La autora colige de lo anterior lo siguiente: "Sólo cuando el hombre y su circunstancia son vistos con amplitud en sus manifestaciones vitales estamos ante una generalización; en cambio, particularizar supone aumentar el acento sobre la circunstancia, simplificando el carácter, pudiéndose lograr un análisis más detallado de la colectividad como generadora de la circunstancia histórico-social". ${ }^{147}$

La generalización lleva a trabajar con un material probable (realismo), con caracteres complejos y la configuración dinámica del choque dramático. La particularización presupone

\footnotetext{
146 Hernández, op. cit., pp. 210-211.

${ }^{147}$ Alatorre, op. cit., p. 17.
} 
trabajo con un material posible (no realismo), con caracteres simples y la acentuación de las características de los movimientos sociales, morales, históricos. En este caso, probable será algo que sucede continuamente o sucede casi siempre o se refiere a características y actitudes humanas que han sido así a través del tiempo. Y posibles serán aquellos que pudieran ocurrir alguna vez pero que no ocurren continuamente. ${ }^{148}$ Así, juzgar el material de un drama entre probable o posible se fundamenta en el análisis de la complejidad del carácter y el tipo de circunstancia que enfrenta. Indica Alatorre que la pieza va a representar el marco histórico que viven los personajes por un camino diferente al de la tragedia. Sitúa todo lo relativo a la infraestructura de una sociedad como el "plano cósmico" y lo que se refiere al sistema ideológico u orden cósmico trágico, queda representado a través de la conducta e ideas de cada uno de los personajes. ${ }^{149}$

Por su parte, Lizárraga dice que Hernández sigue libremente a Aristóteles cuando expone que lo probable es aquello con lo cual se puede establecer una relación causal casi de forma inmediata, una relación de causa y efecto establecida como ley. En parte también le suscribe Knowles, cuando afirma que lo que se puede probar con suma facilidad, dada su verosimilitud de acción y contexto, es lo que se puede denominar en un texto dramático como probable. En ese sentido, la pieza es probable porque lo que se pone de manifiesto es el mecanismo psicológico de la frustración y la compensación. ${ }^{150}$ Este mecanismo marca el quehacer de la vida diaria y cotidiana de un ser humano. Advierte que se habla de tres tipos de materiales: probable, posible e imposible. ${ }^{151}$

\footnotetext{
148 Véase Ibid., pp. 16-18

${ }^{149}$ Véase Ibid., p. 52.

${ }^{150}$ Este mecanismo se ampliará en el apartado del personaje.

${ }^{151}$ En estos tres materiales Garrido coincide con Lizárraga. Por otro lado, primero dice que se les llama así porque de ellos se nutren las obras para construirse, después acomodará su postura y dirá que los tres tipos de materiales no son más que diferentes tipos de relaciones [de la obra] con la realidad.
} 
El material probable es equivalente al realismo y, como se ha adelantado, a toda observación artística que pueda reducir al drama a explicaciones de causa y efecto, de manera coherente y acorde con la realidad; las obras realistas encierran verdades psicológicas, sociales y cósmicas del comportamiento humano, que se hacen comprensibles desde el contexto en el que se está, y que se pueden en un momento dado elevar a leyes de comportamiento universal; sus personajes se reconocen porque actúan bajo determinadas circunstancias en las que sus pasiones pueden desbordarse y entendemos por qué causas se presentan las diferentes cosas que suceden. En esta categoría se encuentra, además de la tragedia y la pieza, la comedia. El material posible es más singular e histórico (en concordancia a lo dicho por Alatorre) y su existencia es generalmente única, particular o extraordinaria; sus personajes funcionan a base de un solo objetivo a nivel de texto, distinto al personaje de la obra probable cuyos variados objetivos, incluso, pueden contraponerse entre sí. El melodrama, la tragicomedia y la obra didáctica se incluyen en esta categoría. Por último, el material imposible se llama así por su capacidad de sustitución simbólica de la realidad; el símbolo se encarna en un ser como si fuera real, nutriéndose tanto de material probable como posible. En este último caso encontramos a la farsa.

Algunas conclusiones se pueden señalar de lo expuesto anteriormente. Primero, podemos encontrar que no hay un consenso en cuanto a un rótulo, a diferencia de la claridad con que se presenta el de concepción, para el elemento estructurador que defina la relación que existe entre la realidad y las siete categorías genéricas planteadas por Hernández. Quizá el único que le da una etiqueta es Tovar, al decir que cada obra tiene un enfoque y que, en ese sentido, el enfoque de la pieza es realista. Recordemos que Tovar ofrece un esquema que tomó de las clases de Hernández, así que podemos asumir que dicho rotulo se presta para que dentro de él se reflexione cuál es la relación que tienen las obras con la realidad. Así, podemos llegar a señalar 
que tal enfoque puede ser realista o no realista (o simbólico), dependiendo de la categorización que hagamos de esa relación, en este caso, si es probable, posible o imposible.

Sin embargo, la construcción de dicha relación, como se expuso especialmente con Knowles, Hernández, Alatorre y Lizárraga, contiene los problemas sobre el realismo artístico propuestos por Jakobson. Por una parte, se hace referencia al realismo como el movimiento del siglo XIX en dos sentidos (Knowles y Hernández). Primero, se le identifica con cualquiera de los otros estilos, como el romanticismo o el naturalismo, en tanto, al igual que ellos, no puede ser total, por falta de espacio intelectual, emotivo y factual; lo que se resume en los métodos usuales del arte de síntesis y selección. El segundo aspecto es el que deviene del problema de la representación que trajo consigo el agotamiento del melodrama -como apuntaba Knowles-, o el de la Pièce bien faite -como se señaló en un principio-, y que tanto el naturalismo como el realismo vinieron a solucionar, en un entrecruzamiento de diferentes factores que incluyen posturas venidas desde el romanticismo, lo que dio como resultado el surgimiento de la pieza en el campo del teatro.

La otra manera en que opera el realismo, tanto en la teoría de los siete géneros como en la pieza, refiere a cómo la realidad es vaciada en el material dramático. En este caso, el más comentado y acordado, se asume un paradigma de realidad y de valores vigentes comunes tanto para el autor como al espectador o lector. El realismo va a estar ligado a cierta coherencia entre la plasmación artística y un marco referencia dado por la realidad objetiva. De esta coherencia se extrae que el tratamiento a tal realidad puede ser probable, posible o imposible. Desde esta perspectiva, lo probable tendrá que ver con dos factores. El primero, es referente a la construcción del personaje. Los autores coinciden en que el personaje de una obra realista y probable es complejo. Esto quiere decir que su cercanía con la realidad, la ilusión de paridad con cualquier ser humano -ese gran marco de referencia movible--, está en la capacidad del 
dramaturgo de entregarnos personajes con naturaleza contradictoria; plurívocos, no con un solo objetivo, sino varios que incluso se pueden rechazar mutuamente.

El segundo factor, alude a que el material dramático sea puesto a pruebas de verosimilitud, casi científicas y de causa y efecto, a los paradigmas de realidad dentro de los que se encuentra quien reflexiona sobre la obra (con verdades psicológicas, socio-históricas y acordes con el comportamiento humano dentro de su contexto). Nos encontramos así que, desde el siglo XIX, ciertas preocupaciones estéticas empezaron a girar en torno a individuos comunes y corrientes, las pasiones humanas (éstas sí, universales y constantes históricas) y el contexto histórico. Para Hernández tiene que ver con la manera en que el dinero se convierte en acondicionador de conductas, para Lizárraga es un foco que se extiende hasta los quehaceres de la vida cotidiana. Así, la pieza se alza como un género de enfoque realista porque el material con el que se construye es probable de acuerdo con su relación con la realidad (en este caso contemporánea y vigente), puesto que la exposición de sus temas y su concepción se esboza como paridad al marco histórico-social, el sistema ideológico imperante y el hombre que vive inmerso en tales marcos.

El otro elemento que tiene directa referencia a la realidad es el tono. Según Kurt Span, ${ }^{152}$ tono, etimológicamente, se deriva del griego tonos y del latín tonus que originariamente significan tensión y también sonido. Spang concibe, en toda su amplitud y diversidad, a los tonos como derivaciones y consecuencias físicas y sensoriales de afectos, entendidos éstos en el sentido amplio de estados anímicos. Coincide con Bajtín, para quien el tono estructura determinada entonación expresiva, puesto que el hombre no puede no expresarse sin afectos, lo que conlleva a que no puede expresarse sin tonos: "Como ocurre con otras condiciones

\footnotetext{
${ }^{152}$ Kurt Spang, Acerca de los tonos en la literatura, en Revista de Literatura, 2006, julio-diciembre, vol. LXVIII, n 136 , págs. 387-404.
} 
psicológicas, exceptuando las patológicas, el hombre no puede vivir en un estado indiferente, en nuestro caso afectivamente indeterminado. No hay posible neutralidad afectiva; he aquí el motivo por el cual los afectos siempre repercuten en el tono de las exteriorizaciones humanas". ${ }^{153}$ Esto denota en que los afectos y los correspondientes tonos son elementos fundamentales en la configuración de una serie de temas y en la particular caracterización de cada forma de expresión (suponemos que de allí su relación la realidad objetiva). En ese mismo sentido, "son también responsables de las repercusiones que puedan tener sobre los receptores, ya que funcionan como una especie de catalizadores que inician y mantienen la «sintonización» con la base afectiva y tonal de un mensaje". ${ }^{154}$ Finalmente va a concebir al tono como exteriorización sensorial de los afectos en actos de comunicación, verbales y extraverbales. Ontológicamente hablando el tono es la materialización física de un 'movimiento anímico’ que conlleva la transitoriedad y lo pasajero del afecto, manifestado a través de los signos de un determinado código.

Sin embargo, Luisa Josefina Hernández, en el texto que hemos venido citando, no se refiere directamente al tono como un elemento para definir al género, por lo tanto ni para definir la pieza ni la tragedia; lo mismo ocurre con Tovar, pero no con Alatorre, Rivera, Garrido, Lizárraga ni Knowles. No quiere decir que la autora no tenga en cuenta al tono como un elemento estructurador, pero tal noción puede llegar a ser muy difícil de sostener dada su versatilidad, inmensamente más subjetiva que la de realismo. Pero con lo expuesto anteriormente con Spang, podemos tratar de ver qué dicen los autores que sí se aventuran a definir tal elemento y su operatividad en la pieza, con el añadido de que quizá es uno de los

${ }^{153}$ Ibid., p. 391. En Géneros literarios (nota 27), p. 35, Spang define que tono "es la capacidad de evocar atmosfera, emociones, humores; me refiero a lo cómico, lo trágico, lo satírico, lo melancólico, lo jocoso, lo lúdico, lo grotesco y un largo etcétera".

${ }^{154} I d$. 
elementos estructuradores donde más coinciden, directa o indirectamente, tanto en el nombre del elemento como a lo que refiere.

Para Rivera, tono y estilo son la consecuencia de la posición objetiva del autor ante la vida en general, y de su posición subjetiva ante el pequeño fragmento de vida que maneja en cada texto. Para Knowles, el personaje trae consigo un mundo del cual no puede separarse y este mundo es distinto a lo que normalmente se toma por realidad, siendo esta realidad el nivel por el que el público se interna en la obra. A esa relación ente la obra y esa realidad objetiva es lo que él llama tono. ${ }^{155} \mathrm{El}$ tono de la pieza va a evocar fuertemente la naturaleza de la realidad objetiva, parecérsele estrechamente, retratarla. Para que el dramaturgo alcance ese tono, cuida a su personaje y al mundo que crea al envolverlos con aíre "real"; es por eso que debe "captar los dinamismos de carácter y situación tal como operan en la vida de los espectadores; el carácter ayuda a confrontar y definir un medio ambiente y una situación, y a su vez, resiente profundamente el control y los límites impuestos por el mismo medio que él ayudó a crear”. 156 En su esquema, Garrido define el tono de la pieza de manera muy sencilla y en ello coinciden la mayoría de nuestros autores: el tono de la pieza es medio, serio, cotidiano (puede tener ribetes trágicos, cómicos o ambos).

Alatorre propone para sustentar la anterior afirmación que la escala infinitesimal con que se mide la acción en la pieza es la clave para considerar su tono. Como en la concepción, el cambio apenas perceptible del vivir diario impone su ritmo. Si tenemos que en la pieza las transformaciones no son muy grandes y que la acción se concentra en pocos espacios, sino es que en uno solo, la velocidad que resulta de combinar tales vectores es tremendamente insignificante. Somos espectadores de varias acciones (especialmente internas), las cuales,

\footnotetext{
${ }^{155}$ Knowles, op. cit., p. 22.

${ }^{156} \mathrm{Id}$.
} 
además, tienen su propio ritmo, cuyo origen es la realidad. Aquí se acerca a la definición de Spang, pues lo que se genera para la percepción del espectador son personajes muy contenidos; ante la simultaneidad de las acciones se crea la ilusión de que el ritmo es tan lento y diluido como el de la vida real (Alatorre dirá que la pieza es la exposición de un grito diluido). ${ }^{157}$

Otra forma de ver lo anteriormente expuesto, es lo planteado por Lizárraga. Si se acepta que el tono de la pieza es cotidiano, quiere decir que, según señala Lizárraga que dice Hernández, lo cotidiano en un texto dramático es la imitación poética del acontecer diario. Lizárraga acude a Heidegger, quien: "define la cotidianidad de manera fenomenológica, diciendo que ella hace que se viva en el se [se dice, se viste, se habla] donde los demás hacen que se viva como ellos, se hable como ellos, se actúe como ellos, el se es una estructura constitutiva del ser humano [...]. Según Heidegger, la existencia del ser humano es implacablemente heterónoma". ${ }^{158}$ Se puede renunciar a cada una de nuestras obligaciones, pero esto lleva a otras posibilidades, donde nos someteríamos a otras presiones. La vida cotidiana obliga a plegarse a la dictadura del se, nada escapa a su dominio: preocupaciones, placeres, sentimientos, ideas, todo en el plano de la vida diaria. El se es el Ser-ahí: "el ser humano en su existencia inauténtica. Es él, y no yo, el verdadero sujeto de la vida cotidiana. La servidumbre del se no impulsa al hombre hacia un ser exterior al suyo propio, sino hacia un cierto modo de sí que consiste en no ser sí mismo". ${ }^{159}$ Ahora bien, la vida diaria en sí no es dramática, se dramatiza en tanto se hace una metáfora con ella, y la forma del funcionamiento metafórico de ella, aunque parezca paradójico, exalta pequeños detalles de vida cotidiana y mezquina, y los hace poesía, "transformándolos casi en elementos cósmicos. Los resignifica, los lleva de un

\footnotetext{
157 Alatorre, op. cit., 62-63.

${ }^{158}$ Lizárraga, op. cit. p. 71. Heterónoma refiere a que se somete a las leyes y costumbres.

${ }^{159} \mathrm{Id}$.
} 
plano cotidiano, plenamente reconocible e identificable por el público, a un plano extracotidiano donde se resignifican y matizan". ${ }^{160}$

\subsection{Catarsis: la obra y su relación con el público}

En su entrada sobre catarsis, Pavis señala que esta palabra viene del griego katharsis

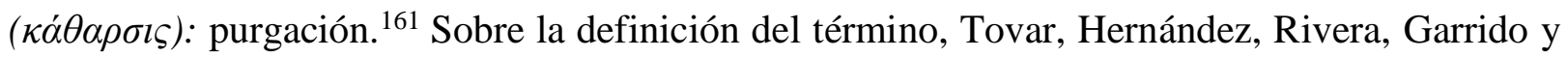
Lizárraga consensan en doxar lo que dice Aristóteles en la Poética:

la tragedia es, pues, la imitación de una acción de carácter elevado y completa, dotada de cierta extensión, en un lenguaje agradable, llena de bellezas de una especie particular según sus diversas partes, imitación que ha sido hecha o lo es por personajes en acción y no por medio de una narración, la cual, moviendo a compasión y temor, obra en el espectador la purificación propia de estos estados emotivos. ${ }^{162}$

Pavis recuerda que catarsis es un término médico "que asimila la identificación a un acto de evacuación y descarga afectiva; no es raro que de ella resulte una 'limpieza' y una purificación a través de la regeneración del yo receptor". ${ }^{163}$ Por su parte, Hernández aclara que "El intenso sufrimiento del público debe ser un punto básico para establecer diferencias [entre un género y otro], justamente por lo mucho que se parece a la teoría de la catarsis por medio de la identificación". ${ }^{164}$ Garrido lo define como el "efecto en el público", Tovar como la "función”, y Knowles habla de "la relación que existe entre el público y la obra". De hecho, Bentley asegura que el "fin" que persigue un drama de primera clase no es ni el suspenso ni la sorpresa,

\footnotetext{
${ }^{160}$ Ibid., p. 72.

${ }^{161}$ Pavis, Patrice Pavis, Diccionario del teatro. Dramaturgia, estética, semiología. Editorial Paidós, Barcelona, 1998, s.v. Catarsis

162 Aristóteles, op. cit., pp. 37-38. Cabe señalar que Pavis y Bentley doxan igualmente a Aristóteles.

163 Pavis, op. cit., s.v. Catarsis.

164 Hernández, op. cit., pp. 206-207.
} 
sino que la audiencia se estremezca de horror (o temor) y piedad; sentimientos que, mediante la tragedia, provocan su propia catarsis. ${ }^{165}$

Las coincidencias se tornan alrededor de la idea de que el público se identifica con el héroe y que los sentimientos de temor y compasión surgen simultáneamente. Para Alatorre, el sentimiento de temor o terror "lo produce la identificación del espectador con el protagonista, como si viviera a través de él las consecuencias de un acto probable en nosotros”. Por otro lado, la compasión coloca al espectador en la perspectiva de lo social, “es ‘el otro’ que juzga desde su 'otredad' al protagonista"; así, el terror y la compasión guardan una relación dialéctica y complementaria, y se derivan de la reflexión que hace el espectador sobre las consecuencias individuales y sociales que tienen los actos humanos: "La catarsis representa el momento más intenso en este juego que debe realizarse intelectual, afectiva y lingüísticamente; tanto en el carácter concreto, como en la situación concreta”. ${ }^{166}$ Lizárraga, por su parte, asiente que el espectador constata un hecho que confronta consigo mismo y por esa vía se juzga a sí mismo, aunque también "lo que le sucede al personaje desafortunadamente ya está pasando, pero pasa en un nivel de ficción escénica; el público sufre con la mentira poética que plantea el dramaturgo con la realidad imitada que se presenta en el juego de luz y oscuridad, pero este sufrimiento no deja de ser teatro". 167

Pavis también apunta que la purgación producto de la catarsis "está vinculada al trabajo de lo imaginario y a la producción de la ilusión escénica. El psicoanálisis interpreta la purgación como el placer engendrado por nuestras propias emociones ante las emociones del otro, y el placer de sentir una parte de su antiguo yo reprimido, el cual toma el aspecto tranquilizador del

\footnotetext{
${ }^{165}$ Bentley, op. cit., pp. 40-41. Si no es evidente, recalcamos que también parece ser una coincidencia general que toda obra dramática, sea cual sea su característica textual o género -es decir, más allá de la tragedia definida por Aristóteles-, tiene como fin generar algún efecto en el público y que tal efecto es asociado con la catarsis.

${ }^{166}$ Alatorre, op. cit., pp. 245-247.

${ }^{167}$ Lizárraga, op. cit., p. 53.
} 
yo del otro". ${ }^{168}$ Este mismo autor plantea que la identificación es el proceso de ilusión del espectador que imagina ser el personaje representado; asimismo, señala que la identificación con el héroe de una obra tiene profundas raíces en el inconsciente y en la búsqueda de placer estético. Este placer estético provendría, según Freud citado por Pavis, “del reconocimiento catártico del yo y del otro, del deseo de apropiarse de este yo, pero también de diferenciarse". Pavis también recuerda que la identificación con el personaje es uno de los criterios del placer y la comunicación teatral. Tal proceso implicaría que:

El espectador esté capacitado por el estilo de representación $-\mathrm{y}$, en consecuencia, por las motivaciones ideológicas- para juzgar al personaje: éste deberá tener algunos atributos del héroe. Si juzgamos a este héroe como "mejor" que nosotros, la identificación se hará a través de la admiración y de cierta "distancia" inherente a lo inaccesible; si lo juzgamos inferior, pero no del todo culpable, la identificación se hará por medio de la compasión. ${ }^{169}$

Hernández ubica las raíces de la catarsis en la ritualidad trágica de las "festividades primaverales con que los griegos celebraban la renovación del año y, a través de una muerte simbólica, el renacer del hombre purificado para un año más". ${ }^{170}$ Por tal razón la representación de la tragedia es percibida por el público en un plano cósmico ajeno a la vida cotidiana y en el que asisten a morir y nacer simbólico. En el caso de la reacción del público ante una obra de Chéjov (o una pieza) la identificación se debe a que el espectador se ve enfrentado a la realidad de la vida cotidiana "colmada de detalles domésticos, suficientemente efectiva como para ser reconocida, vivida, lamentada al igual que la vida diaria, el público no halla más reacción emotiva que sufrir; no renacer, aceptar: así es y así será”. ${ }^{171}$

\footnotetext{
168 Pavis, op. cit., s.v. Catarsis.

169 Pavis, op. cit., s.v. “Identificación”.

${ }^{170}$ Hernández, op. cit., p. 207.

${ }^{171}$ Id. Recordemos aquí el papel que desempeñó la prosa para romper la barrera entre las representaciones teatrales y el público.
} 
Con esto tenemos que, según Garrido, el efecto de la pieza en el público es catártico (a diferencia de la comedia, cuyo efecto, según la autora es moral); ${ }^{172}$ y según Tovar, la función de la pieza es la catarsis por identificación, compasión (igual que la tragedia, pero distinto al melodrama, cuya función es el "ejercicio de los sentimientos"). ${ }^{173}$ También en su esquema Alatorre suscribe con las mismas palabras a Garrido pero amplia al subrayar que el héroe de la pieza se sobrepone calladamente a la vida diaria y que, como el espectador, "sabe bien que, aun en las más grandes tormentas personales, se sigue trabajando, comiendo y durmiendo, que nadie es héroe". ${ }^{174}$ Para esta autora, la pieza es un grito diluido, por lo tanto provoca una catarsis diluida:

casi desde el principio, el espectador queda situado frente al marco de referencia que se está proponiendo; así, se cierra la síntesis escena-espectador que propicia el clima de la catarsis, cuando ésta ocurre al final, digamos que es el resultado de la suma de energía de cada escena, conforme se va acercando al desenlace, aumenta la tensión dramática y el espectador ve ante sí las proporciones gigantescas de lo que antes había creído cotidiano y pequeño; y entonces sí sucede la verdadera catarsis: la visión fulgurante del todo. ${ }^{175}$

Según Lizárraga, los personajes de la pieza viven en una constante evasión de los conflictos, pero al final de cuentas se encontrarán con un momento en que sus problemas aparecen de manera irremediable. Sin embargo, esta situación estalla en el ámbito de sus ilusiones, deseos, proyectos, etc., así, el espectador no presencia grandes acciones externas que modifiquen la conducta de los personajes, sino que, como señalamos con Alatorre, se reafirma una acción que ha venido realizándose, un sentido general de la acción. ${ }^{176}$ Lizárraga sostiene

${ }^{172}$ Garrido, op. cit., p. 103.

173 Tovar, op. cit., p. 58.

174 Alatorre, op. cit., p. 63.

${ }^{175} \mathrm{Id}$. Sería interesante profundizar en este momento fulgurante para analizar cómo en esa visión fulgurante de toma de conciencia del personaje se le da forma a la unidad dramática aristotélica que, se supone, un género como la pieza no tiene. Si hemos sostenido que la pieza tiene como característica la inconexión entre un postulado inicial y su desarrollo, en el momento en que el héroe de la pieza se estremece ante la resignación de que la vida es tal cual cómo le tocó, todos esos aparentes momentos prosaicos del cotidiano toman forma y unidad en esa "visión fulgurante del todo".

${ }^{176}$ Lizárraga, op. cit., p. 54 
que el espectador siente compasión por los personajes de la pieza porque considera que no merece ser desafortunado, con lo que nos encontramos con que la compasión es un regodeo del público ante una aparente superioridad sobre el personaje. Sin embargo:

Esta supuesta superioridad es la ficción de la pieza, de hecho, ella lo único que viene a decir es que el ser humano puede sufrir así en la vida; de ahí la gran fuerza del mecanismo de la identificación; pues la humanidad entera quisiera objetivar ese sufrimiento, para así sentirlo completamente ajeno a ella; en su intento de objetivarlo. Irónicamente lo que sucede es lo contrario: se identifica con el personaje y sufre con él, padeciendo de esta manera una purificación o catarsis en el más puro y estricto sentido aristotélico. ${ }^{177}$

La palabra compasión proviene del "latín cumpassio, calco semántico o traducción del vocablo griego $\sigma v \mu \pi \alpha ́ \theta \varepsilon ı \alpha$ (sympathia)". El origen de su acepción literalmente se refiere a un ‘sufrir juntos'. Milan Kundera, en La insoportable levedad del ser señala:

En los idiomas derivados del latín, la palabra «compasión» significa: no podemos mirar impertérritos el sufrimiento del otro; o: participamos de los sentimientos de aquel que sufre. [...] El secreto poder de su etimología ilumina la palabra con otra luz y le da un significado más amplio: tener compasión significa saber vivir con otro su desgracia, pero también sentir con él cualquier otro sentimiento: alegría, angustia, felicidad, dolor. ${ }^{178}$

Aunque Kundera procura despojar la el consenso de que la compasión es una emoción humana que se manifiesta a partir del sufrimiento del otro, mantiene la idea de que la compasión describe la capacidad que tenemos de entender el estado emocional de otro, que cuando se trata de dolor se acompaña con el deseo de aliviar o por lo menos reducir su sufrimiento. Sin duda en la catarsis, como fenómeno, se evidencia el encuentro entre el público y lo representado y que el conducto para tal viene siendo lo ideológico. Así, en la misma dirección en que Althusser amplía el concepto de la identificación más allá de lo psicológico, reconociendo también en la conciencia espectadora el contenido ideológico de la obra,

\footnotetext{
177 Ibid., p. 59.

${ }^{178}$ Milan Kundera, La insoportable levedad del ser, trad. Fernando Valenzuela, Tusquets Editores, México, 2002, pp. 26-27.
} 
Hernández ve que en las piezas de Chéjov "los factores que rigen la vida del hombre son el dinero y la habilidad para generarlo, lo cual suena prosaico, evidente y hasta vulgar, pero es una verdad tan profunda como alejada de los temas trágicos". ${ }^{179}$

Según Pavis, por medio de los personajes y la fábula el espectador se adhiere a los mitos y creencias de su ideología cotidiana: “identificarse siempre es dejarse impresionar por la 'evidencia' solapada de la ideología. ${ }^{180} \mathrm{Si}$ dicha identificación tiene efecto a razón de la comprensión que el espectador vive la puesta en escena, podemos considerar -y aquí creemos que está el centro del efecto catártico de la pieza- que más que compasión el público está expuesto a una autocompasión, a un sentimiento de pena por sí mismo; no sentimos piedad y compasión por el hombre común y sus angustias, sino que nos impresionamos de que el calificativo y la categoría de "hombre común" se aplica a nosotros mismos y a nuestras propias tribulaciones, y especialmente ante la conciencia de que éstas estarán allí a nuestro lado y por siempre porque la vida diaria es por sí sola una vida de tribulaciones.

\subsection{Personaje: La vida cotidiana y trayectoria (o dinámica) del personaje}

Probablemente la noción de personaje sea la que menos se discuta dado que su central participación en la obra es obvia; sin embargo, profundizar en sus aspectos particulares dentro del género de la pieza se hace relevante cuando todos nuestros autores, siguiendo a Luisa Josefina Hernández, señalan que a partir del personaje - de la atención que prestamos a su trayectoria en la obra, del conflicto que desarrolla con sus pares o su contexto y de la resolución de dicho conflicto- podemos definir ante qué género nos encontramos.

\footnotetext{
${ }^{179}$ Hernández, op. cit., p. 207.

${ }^{180}$ Pavis, op. cit., Identificación.
} 
Quizá el autor que más ha profundizado en la composición del personaje de la pieza es Gustavo Lizárraga, quien para describirlo hace una amplia exposición sobre su relación con el mundo cotidiano. Para conocer al personaje hay que conocer el contexto que determina su situación, señala Flavio González Mello, para quien "el personaje no existe independientemente del resto del mundo. Hablar de situación dramática es hablar de relaciones entre el personaje y su entorno". ${ }^{181} \mathrm{Si}$ tenemos en cuenta tal postulado, nos vemos en la tarea de recoger ampliamente la exposición de Lizárraga, pues profundiza en cómo esa dinámica de la cotidianeidad forja el perfil del personaje de la pieza. ${ }^{182}$

Para este autor, la pieza habla de la vida cotidiana del hombre común, aquel que no es noticia ni es considerado de los mejores ni de los viles en el sentido aristotélico. Como se adelantó con Miller, el hombre común sería aquel que recibe su heroicidad a partir de la ausencia de acontecimientos trascendentes, aquel que habita como mayor puede su cotidianidad. La selección del material dramático de la pieza es una parcela del mundo donde acontecen el reino de los deseos, los anhelos, los proyectos y las añoranza enfrentadas a la lucha por la existencia cotidiana, cuyo resultado serán pequeñas realizaciones o frustraciones donde el hombre asume o no las consecuencias de su propia libertad. Así, la pieza representa sentimientos de frustración muy grande y desgarradores nacidos de la ilusión.

La ilusión sería un mecanismo de defensa común al ser humano y consiste en una relación de desequilibrio entre el principio de deseo y el principio de realidad: "la inadecuada proyección de deseos es la ilusión que consta de dos momentos diferentes: el anhelo (una ilusión proyectada hacia el futuro) y la añoranza (una ilusión proyectada hacia el pasado)". ${ }^{183}$

\footnotetext{
181 Flavio González Mello, "El rompecabezas incompleto”, en Estudios Cinematográficos, año 10, núm. 28, México, 2005, p. 27.

${ }^{182}$ Lo que sigue en adelante es tomado de Lizárraga, El mundo cotidiano y la pieza, en op. cit.

183 Ibid., p. 8.
} 
Con esto, la ilusión tiene un mecanismo de proyección que proviene de un deseo y del fracaso de este mismo ante la realidad, así que la ilusión es una forma de adaptación inadecuada del deseo a la realidad. Citando a Freud directamente, Lizárraga resalta que calificamos de ilusión una "creencia que aparece engendrada por el impulso a la realización de un deseo, prescindiendo de su relación con la realidad, del mismo modo que la ilusión prescinde de toda garantía real". ${ }^{184}$

Apoyado en Savater, el autor define al deseo como "el fundamento de la voluntad ética que se da en el querer de la acción; el hombre moralmente activo es el que quiere, el que desea". ${ }^{185}$ En síntesis, es la semilla de la voluntad; pero el deseo contiene una paradoja y es que al actuar como tal se determina y cada una de sus determinaciones le limita: su fuerza mide su insaciabilidad con objetos siempre finitos, que no son más que lo que son. Vemos que el deseo se hace en el querer ser: querer ser el todo y del todo. En ese sentido, el yo, para ser plenamente, necesita de otro yo para verse confirmado y reconocido:

en esta inspiración insaciable el sujeto y todos los seres de su deseo se pierden irremediablemente. El querer infinito descubre que todo es finitud, que nada conserva la tensión de lo posible que la voluntad implanta, salvo como objeto perdido, como ausencia irrevocable. De esta manera el deseo niega, radicalmente, su identidad con alguna cosa. El yo quiere, se niega en su deseo infinito a ser de una manera definitiva: porque él es lo que no es y no es lo que es. ${ }^{186}$

Dos de las formas de manifestarse del deseo son la fantasía y la ilusión, cuyo origen, y siguiendo de nuevo a Freud, es el conflicto entre el principio de realidad y el principio del placer. Esto lleva a Lizárraga a afirmar que la pieza se mueve "dentro del reino del deseo, del querer, pero de un querer convertido en ilusión; ésta puede tomar el sesgo de anhelo o la añoranza que va irremediablemente hacia la frustración cotidiana o hacia las realizaciones

\footnotetext{
${ }^{184} I d$.

${ }^{185}$ Ibid., pp. 8-9.

${ }^{186}$ Ibid., p. 9.
} 
diminutas como quereres ilusionados". ${ }^{187}$ La frustración se vendrá a ocultar en un proyecto basado en una idea ilusoria que se ve proyectada en las añoranzas o los anhelos y la derrota o compensación de sus propósitos. Así, el conflicto interno en el individuo viene a existir, pues las añoranzas y los anhelos seguirán alimentando la ilusión; por tal, las intenciones que se basan en ella continuarán, y eso es lo que alimenta el fracaso y a los pequeños logros de la vida cotidiana. Con esto, el autor afirmará que el sentimiento que refleja la pieza es universal, porque el hombre nunca dejará de tener ilusiones y proyectos sobre ellas, así como tampoco cesarán los desencantos por la imposibilidad de realizarlos, lo cual se establece como un continuo eterno retorno: de la ilusión al fracaso y del fracaso a la ilusión. Finalmente, la persecución del cumplimiento del deseo opera como un mediador con la realidad. En dicha operación se define la mecánica de lo cotidiano. Sin embargo, a pesar de su universalidad e, incluso, su atemporalidad, sólo a partir de mediados del siglo XIX, como ya se expuso, se focalizará y se pondrá atención a los procesos de la vida cotidiana, al hombre común y a la concientización del obstáculo que oponen la añoranza o el anhelo a la lucha cotidiana de la existencia.

De esto resulta que la pieza contará la historia del personaje en el reflejo de las frustraciones y las compensaciones: en su capacidad de convertir al deseo en ilusión y en la capacidad de las ilusiones de ser selectivas; a su vez, tal elección reflejará las frustraciones a las que se ha visto reducido cotidianamente el personaje que se ilusiona y que ve cómo esto malogra su realidad. Es allí donde se refuerza la idea de que la pieza nace, según Luisa Josefina Hernández, cuando el concepto de héroe aristotélico de héroes o reyes como personajes centrales es derrotado por el individualismo. Ahora, todos los hombres pueden ser trágicos, aunque en compensación lo son pocos: "La exaltación está fuera de contexto en una sociedad que ofrece al hombre algo valioso: una supervivencia no necesariamente deshonrosa de acuerdo

${ }^{187}$ Ibid., p. 10. 
con los valores colectivos: el valor de la vida cotidiana. Por otra parte, las pasiones quedaron sustituidas en vigor y en pureza por deseos, amores, rebeldías, etc., es decir, en el momento en que deviene a la conciencia humana la posibilidad de imitar el mecanismo de la frustración”. ${ }^{188}$

Esto repercute en un hombre que no lleva sus pasiones hasta las últimas consecuencias; así que, más que conciencia de la frustración, lo que existe es la necesidad de una mesura cotidiana, poco heroica: la aceptación. El punto culminante de la frustración en el personaje de la pieza será, entonces, la aceptación, pues ésta se da a partir de una ilusión proyectada, consciente o inconscientemente, sea como anhelo, añoranza o ambas. Finalmente, la aceptación consistirá en asumir la inviabilidad de sus deseos ante la cotidianidad aplastante.

Por otro lado, en la pieza no debe pasar nada que atente contra los valores establecidos, es por eso que en ella nada se desborda de manera exterior: los sentimientos del personaje, por más fuertes que sean, no se exteriorizan. De esta manera, Lizárraga concluye que las reacciones del personaje de la pieza no son más fuerte que sus estímulos:

Existirá un contrasentimiento que evite su manifestación, generando así una exteriorización del personaje normal o neurótica; esta presentación de la pieza es un ejercicio de introspección que debe mostrarse en un punto en el que aparentemente estalle como conflicto, pero no lo hace porque no hay donde pueda devenir externamente la acción, por que el personaje no se da el espacio para ello; la acción del sentimiento se mostrará siempre como contención. ${ }^{189}$

Tal contención lleva al personaje de la pieza a aceptar vivir a pesar del dolor que siente de seguir haciéndolo; la vida cotidiana "normal” no está llena de energía o de la decisión necesaria para estallar y dejarse llevar por las pasiones, anormalidades o inmoralidades que están fuera de lo esperado. Dicha reacción o tensión interna que paraliza al personaje también está fuera de los

\footnotetext{
${ }^{188}$ Ibid., p. 13. Para la percepción y el gusto que se disfruta de la imitación de los mecanismos de frustración es totalmente moderna.

${ }^{189} \mathrm{Ibid}$., p. 15. El autor lo ejemplifica con el momento en que el Tío Vania intenta matar a Serebriakov y matarse a sí mismo, pero no lo hace. Finalmente, los personajes en la hacienda se quedarán igual que antes de la llegada del profesor Serebriakov y su esposa, trabajando para éstos y cayendo en la frustración pero con el orgullo de hacer lo que se debe. Esto será la pequeña realización personal de los personajes en que basa la obra de Chéjov.
} 
parámetros aristotélicos de lo que se considera acción o peripecia. ${ }^{190} \mathrm{Al}$ final, la exhibición de la mecánica de la frustración y de sus pequeñas satisfacciones en la pieza muestra un retorno a una situación establecida; es decir, el personaje retorna a la realidad, le sea odiosa o no.

Otra perspectiva de lo planteado por Lizárraga, se da cuando expone cómo, apoyado en Heidegger, el cotidiano es el estado de "arrojado en un mundo" en el que vive el ser humano. La derrota que consiste en saberse impotente de emprender grandes acciones o conocer de antemano el fracaso al intentar emprenderlas, porque finalmente se imponen una serie de normas sociales, morales, éticas e ideológicas que no dejan accionar al individuo. Según Lizárraga, para Heidegger:

...la forma de ser más inmediata del ser-ahí ${ }^{191}$ es la cotidianidad: ésta se caracteriza por su caída en el olvido; por su estado de yecto; por la banalización de la existencia, esta caracterización existenciaria del ser del ser ahí, no se debe tomar en un sentido moral; antes bien, debe tener un estricto sentido ontológico [...] El ser en el mundo es un existenciario, ${ }^{192}$ es decir, una determinación estructural del existir humano, una forma propia del ser ahí. Esto quiere decir, en sentido estricto, sólo el ser ahí puede tener existencialmente mundo. ${ }^{193}$

Expone Lizárraga que el ser ahí se relaciona de golpe con el mundo que es el suyo; tal golpe lo tira o lo hace caer en lo que precede y hace posible todo conocimiento: "En la existencia cotidiana, en su modo de ser existencial, el ser-ahí no se relaciona con el mundo de manera neutra y desinteresada, sino que está cerca del mundo. El ser cerca del mundo es una

190 Lizárraga entiende que la peripecia es "ese gran movimiento externo de los personajes que pueden en la tragedia culminar ya sea en la muerte o la sublimación y que en la comedia termina en ridículo". Pero cabe recordar que Aristóteles considera a la anagnórisis como una transición de la ignorancia al conocimiento, lo que no exime a la peripecia de mantenerse en el campo psíquico y no sólo en el físico. La peripecia en la pieza puede ser un cambio en el punto de vista del personaje con respecto a su entorno. Así continúe con su misma realidad en el exterior, el personaje llevará su vida con una nueva conciencia de esa realidad con lo cual, así sea mínimo, lleva a un giro del destino en la trayectoria del personaje. Este nuevo punto de vista puede tener las dimensiones de un acto del habla y traer consecuencias que se podrían considerar del nivel de cualquier otro tipo de acción externa.

${ }^{191}$ Lizárraga recuerda que conceptos como hombre o ser humano están cargados de un significado dado por la tradición de la metafísica occidental que impide la formulación de la pregunta fundamental por el sentido del Ser. Por tal razón, Heidegger prefiere la expresión "Ser-ahí".

${ }^{192} \mathrm{El}$ autor también recuerda que existenciario es una categoría ontológica propia del ser ahí, a sus modo de ser y de existir.

${ }^{193}$ Ibid., p. 22. 
modalidad del ser en el mundo en la cual el ser-ahí está asido y cautivo por su mundo". ${ }^{194}$ El ser ahí se las ve con herramientas disponibles para un uso determinado, que a su vez se remite a cualquier otra cosa que a su vez se remite a otra cosa y así sucesivamente. A la totalidad de referencias que hay en las distintas y múltiples herramienta es a lo que Heidegger llama mundo. Así, el mundo existenciario del "ser-ahí" es un mundo común en el que los otros ya se han anunciado siempre. En la banalidad existencial cotidiana, el "ser-ahí" es acaparado por los otros y se determina en relación a ellos, encontrándose bajo el dominio del otro, desposeído de su ser mismo: "Éste cae bajo la dictadura existenciaria del Uno. El 'ser-ahí' se determina según lo que dice Uno. Se regocija como Uno lo hace, juzga como Uno juzga, lee como Uno lee, etcétera. El Uno no es nada ni nadie y desaloja al 'ser-ahí' de su ser. La dispersión del 'ser-ahí' en el Uno es lo que Heidegger llama la 'caída' del 'ser-ahí'”. ${ }^{195}$

La conclusión de Lizárraga es que la pieza, al hacer patente la mecánica de la vida cotidiana expone la condición de caída en el mundo y "la inhospitalidad de éste que cotidianamente se encubre por las formas de la cotidianeidad como manifestaciones del Uno: el se, el afán de novedades y las habladurías, todas ellas se encuentran expresadas en el mecanismo de frustracióncompensación que imita la pieza”. ${ }^{196}$

Después de la anterior descripción tomada de Lizárraga, entremos en concreto sobre lo que los distintos autores dicen sobre el personaje de la pieza. Lo primero que habría que mencionar es que una de las característica genéricas de la teoría de los siete géneros es definir si el personaje es simple o complejo; como ya se adelantó, el personaje de la pieza es complejo. Según Rivera, el carácter simple es representado con tan sólo unas cuantas facetas del ser humano que son fácilmente definibles ya sea en polos positivos o negativos. Mientras que el personaje complejo se

\footnotetext{
${ }^{194}$ Ibid., p. 23.

${ }^{195} I d$.

${ }^{196}$ Ibid., p. 24.
} 
manifiesta a través de los tres canales expresivos del ser humano: la razón, el sentimiento, el instinto. Por lo tanto, hace uso de muchos más recursos de la faceta humana, con capacidad para tomar decisiones y de la misma manera con conciencia de sus actos en el pasado o en el presente, positivos o negativos y de las consecuencias que traen consigo. ${ }^{197}$ La manera cómo autores como Garrido, Tovar, Alatorre o Knowles definen la complejidad del personaje es diciendo que hay una equivalencia o equilibrio entre sus cualidades y defectos. Esto lo emparenta con el personaje de la tragedia, pero, como se verá, dicha complejidad opera de manera diferente.

Según Lizárraga, Stanislavski señala que el tempo y ritmo en los personajes de Chejov son varios y contradictorios: "Con frecuencia, piezas o papeles enteros transcurren con la combinación de varios tempo/ritmos contradictorios. Muchas piezas y personajes de Chejov están construidos sobre esa base: el Tío Vania, Astrov, Sonia, las tres hermanas y otros personajes están casi siempre tranquilos exteriormente, pero agitados y conmovidos". ${ }^{198}$ Tal situación carga de una dimensión compleja al personaje de la pieza, puesto que vive un conflicto que se desarrolla y es más importante en su suceder psíquico que en su acontecer histórico externo. Tal suceder psíquico se expone como un constante contraste entre lo que se muestra y lo que se oculta en el carácter de los personajes, de la manera cómo lleva sus relaciones con los demás y con su medio ambiente.

Lo anterior también se evidencia en la acción dramática de la pieza, pues ésta "funciona como un laberinto interpretativo del acontecer histórico pasado, presente y futuro en relación con el presente en el presente de los acontecimientos de la obra; este laberinto de relaciones es la construcción de la complejidad psicológica de los personajes de pieza, lo que aquí se denomina su 'historia"'. ${ }^{199}$ Así, el acontecer histórico explica el hacer actual de los personajes, como si hubiese

\footnotetext{
${ }^{197}$ Rivera, op. cit., pp. 64-65.

${ }^{198}$ Lizárraga, op. cit., p. 45, apud. Constantin Stanislavski, El trabajo del actor sobre sí mismo en el proceso creador de la encarnación, trad. Salomón Morener, Quetzal, Buenos Aires, 1986, p. 157.

199 Ibid., p. 49.
} 
una introyección de la historia dentro del individuo, lo que puede decirse es su carácter. ${ }^{200}$ Esto se revela por la manera en que aumenta o disminuye la dimensión de los sucesos que ha vivido, confiriendo profundidad y poca claridad en sus acciones, porque éstas están determinadas por su pasado, presente y futuro, por lo que hace patente y por lo que oculta. ${ }^{201}$

Es por esto que, en términos dramáticos, los personajes de la pieza generalmente no muestran sufrimiento físico, lo que representa una gran desviación de la tragedia. ${ }^{202}$ Eso sí, sobresale que el personaje lleva consigo un dolor interno y escondido causado por una clase de visión interior, cuyo efecto captamos gracias a la comprensión de la trayectoria o la dinámica del personaje sobre la acción dramática. Tal trayectoria es otro elemento constitutivo que tienen en cuenta nuestros autores y que además se entrelaza con la dimensión compleja del personaje. Según Knowles, además del equilibrio entre características positivas o negativas podemos reconocer al personaje por su movimiento hacia su fin o meta, movimiento que nace de su psicología. El personaje empieza con una meta fija ${ }^{203}$ que constituye su propósito, al perseguir su ideal encontrará o enfrentará conflictos que le provocan sentimientos crecientes de duda y frustración. Poco a poco llegará a un instante de agudo sufrimiento: la pasión. ${ }^{204}$ El resultado de ésta lleva a una purificación durante la cual el personaje se contempla a sí mismo y a su vida.

\footnotetext{
200 Ibid., p. 50.

201 Ibid., p. 51.

202 Knowles, op. cit., p. 20.

${ }^{203}$ Valga matizar esta "meta fija" esbozada por Knowles, porque quizá aplique para la definición del personaje en general, pero para la pieza sería necesario un replanteamiento de acuerdo a lo que ya hemos dicho anteriormente sobre la estructura inconexa de este género. Para mantener la unidad que da una meta fija, habría que pensar a la pieza, como ya se ha tratado de señalar antes, como un género en que el personaje tiene el destino manifiesto de entender su realidad sobre la dificultad que resulta apreciar la vida desde las inconexión de los hechos que la tejen. Esto se relaciona también con la concepción formal que caracteriza al género.

${ }^{204}$ Knowles explica, y en esto hay una síntesis de lo que describimos con sobre la mecánica de la vida cotidiana, que la pasión es el momento en que el individuo se encontrará frustrado y aterrado por las circunstancias que impiden la consecución de si propósito. Al descubrir esto, "la voluntad lucha con esfuerzo y vigor por la libertad, negando la realidad dictada por las circunstancias. Entonces se llega a una decisión y en ese momento de intensidad extrema, el individuo es el supremo dueño de $s u$ pasado y su presente, de $s u$ carácter y circunstancia". Ibid., p. 26.
} 
La noción de “entender” es también señalada por Hernández, Lizárraga y Garrido, para quien el personaje de la pieza se encontrará en un punto climático en que llegará a conclusiones sobre su propia vida y que antes no había estado en capacidad de vislumbrar. ${ }^{205}$ Alcanzar este nivel de percepción, para Knowles, deriva en que el personaje se ve en la necesidad de reajustar sus propios valores y metas; en otras palabras, es la toma de conciencia del personaje.

Por otro lado, las huellas que seguimos de cerca para apreciar el cambio interno que se da en el personaje durante el transcurso de la obra es lo que se denomina su trayectoria. ${ }^{206}$ Apreciando la trayectoria del personaje, asistimos a un género que pretende iluminar la vida cotidiana y la manera como la llevan los personajes, así como también se recubre su psicología. En ese sentido, teniendo en cuenta la introspección dada al personaje de la pieza, también se puede destacar que la subtextualidad es relevante en el lenguaje usado en la pieza. Si acordamos que ésta es la manera como comprendemos la conducta del personaje, en la pieza se evidenciará la manera como en el control que se ejerce por dominar sus emociones internas, el personaje hace una proyección velada hacia el exterior con palabras que desvían o esconden su verdadera acción o conflicto interno. Según Lizárraga, este encubrimiento se convierte en un misterio por desentrañar: "y lo que este misterio oculta sería el enigma y la completa obscuridad del límite y de las dimensiones cósmicas donde necesariamente, pero no patentemente, se ocultan y se manifiestan los horizontes del Ser". ${ }^{207}$ Este ocultamiento de las dimensiones cósmicas sería otro elemento para diferenciar al personaje de la pieza del de la tragedia. Apunta Lizárraga que el universo trágico tiene las mismas combinaciones tempo/ritmo que la pieza, sólo que en otras dimensiones. La pieza, al hacer énfasis al desarrollo del carácter del personaje, hace un mejor dibujo de su psicología; tal enfoque lleva a la perdida de la magnitud de las dimensiones cósmicas; por su parte, el contraste del tempo/ritmo

\footnotetext{
205 Garrido, op. cit., p. 109.

${ }^{206}$ Knowles, op. cit., pp. 21-22.

${ }^{207}$ Lizárraga, op. cit., pp. 51-52.
} 
en la tragedia está dado por la contraposición entre cosmos (o límite) y carácter humano. Esta contraposición se desarrolla de tres maneras: como una pasión desbordada, como una pasión controlada o sublimada y como un carácter trágico. ${ }^{208}$ Generalmente, el personaje trágico es un hombre que con su conducta ha causado un desorden que alcanza no sólo a su entorno social sino que ha trascendido "al plano de las leyes universales, al cosmos, a lo intocable, a lo sobrehumano; y dentro de la lógica universal el cosmos tiende a ordenarse, a recuperar su armonía con la destrucción de aquel que lo ha alterado". Tal alteración del cosmos es el resultado de una agresión a un dios, como en la tragedia griega, o de un valor ético, en tragedias más modernas. ${ }^{209}$ Como se ha visto, el personaje de la pieza puede llegar a tener pasiones trágicas, pero éstas no son desencadenadas, lo que evita su destrucción.

Según Alatorre, la pieza - considerando que dicho género se aparta de la representación de dimensiones cósmicas y que se concentra en el carácter del personaje y por ende en una mecánica del mundo humano y su devenir histórico, especialmente a través de las transformaciones socioeconómicas-, representa los matices que se dan en una misma clase social y el tipo de relaciones que guardan una clase con la otra; la pieza se vendría a enmarca, entonces, en el capitalismo como una etapa más del desarrollo histórico de una sociedad. ${ }^{210}$ En este mismo sentido, Lizárraga subraya que el problema del personaje de la pieza está relacionado con su bienestar económico pero profundizando en una problemática existencial. ${ }^{211}$ Sin embargo, el mundo económico no vendría a funcionar como una causa de los problemas sino como un síntoma del personaje, pues en ella se representan, como se ha dicho, explicaciones del por qué, para qué y cómo del pasado, el

\footnotetext{
208 Ibid., p. 45.

${ }^{209}$ Lizárraga, op. cit., pp. 38-39, apud. Fernando Martínez Monroy, Arthur Miller: La tragedia del hombre común. Un análisis teórico, Capítulo 1 "All my sons: una tragedia de desesperación”, Tesis de licenciatura F.FyL., UNAM, México, 1991, p. 5.

${ }^{210}$ Alatorre, op. cit., pp. 57-58. Como también se ha anticipado, en este punto coinciden especialmente Hernández y Knowles.

${ }^{211}$ Lizárraga, op. cit., p. 35.
} 
presente y el futuro del personaje, y especialmente las interacciones del individuo y su entorno, exaltando el mundo humano. ${ }^{212}$

${ }^{212}$ Ibid., pp. 37-38. 


\section{CAPÍTULO III}

\section{LA PIEZA COMO ESTÉTICA DE LA DINÁMICA DEL PODER EN LA VIDA COTIDIANA}

De los autores con los que se ha tratado de dar una visión periférica de los elementos estructurales de la pieza, Virgilio Ariel Rivera es el único que apostó a dar un amplio corpus de obras mexicanas y extranjeras bajo esta forma genérica. ${ }^{213}$ Más allá del Tío Vania o El jardín de los cerezos de Chéjov, Rivera propone como piezas, entre las de otros autores foráneos, dramas de Arthur Miller, García Lorca, Nicolai Gogol, Tennesse Williams, Sam Shepard, George Bernard Shaw o James Joyce. A su vez, agrupa bajo la forma de este género y en el espectro mexicano los dramas Felicidad (1955), Fotografía en la playa (1977) y Rosa de dos aromas (1986) de Emilio Carballido, Los frutos caídos (1955) de Luisa Josefina Hernández, La culta dama (1951) y A ocho columnas (1956) de Salvador Novo, Una señorita decente (presumiblemente de finales de los cincuenta) de Federico S. Inclán, Señoritas a disgusto (1961) de Antonio González Caballero, Con la frente en el polvo (1967) de Luis G. Basurto, De pétalos perennes (1981) de Luis Zapata, Las bellas imágenes (1988) de Pablo Salinas y La

\footnotetext{
${ }^{213}$ En su libro, Rivera también señala un conjunto de obras mexicanas o extranjeras que a su parecer se agrupan bajo cada una de las demás formas genéricas que expone a la luz de la teoría de los siete géneros.
} 
puerta (2000) de Edgar Ceballos. ${ }^{214}$ Para una exposición de la pieza como estética de la dinámica del poder en la vida cotidiana, así como también para dar ejemplos del género en su práctica textual o de manera práctica y de su impacto en el teatro mexicano, hemos decidido usar este corpus para procurar ofrecer una comprensión más redonda de lo expuesto en los capítulos anteriores.

En primera instancia, es necesario manifestar que diferimos del corpus de Rivera en lo que concierne a cuatro de las obras de su lista. En tres casos, no ofrece alguna reflexión particular de las obras con respecto a la pieza, como sí lo hace en la mayoría de las obras mexicanas que califica en dicho género. Rosa de dos aromas, de Carballido, es catalogada por el propio autor como comedia y así se puede apreciar; por su parte, A ocho columnas y La culta dama de Novo y Una señorita decente de S. Inclán tienen un perfil más de melodrama que de pieza.

Rosa de dos aromas $^{215}$ es la historia de dos mujeres, Gabriela y Marlene, de distinta clase social (una peluquera, la otra traductora), que después de aceptar que han sido engañadas por el mismo hombre, padre de sus hijos, deciden sacarlo de la cárcel después de haber sido acusado por una alumna mucho menor de edad que lo demandó por acoso sexual. La sola anécdota ya se anticipa cómica, se puede encontrar algunos gags hilarantes, entre los personajes hay un traspaso en el uso del lenguaje -cual Sancho y don Quijote- y, al final, se podría decir, se castiga el vicio mujeriego del marido con la decisión de las mujeres de tomar un dinero prestado a nombre de su don Juan y marcharse las dos con sus hijos al mar. Pero, esencialmente, la obra no es una pieza, porque lo que vemos es la manera como estas mujeres construyen una empatía mutua por un problema que las empara y que las lleva a tomar decisiones definitivas para un beneficio propio, logrando un quiebre en el destino que se suponía hubieran vivido de no encontrarse -soso, de

\footnotetext{
214 Véase Rivera, op. cit., pp. 135-136.

215 Emilio Carballido, Rosa de dos aromas, Fondo de Cultura Económica, México, 2001, pp. 49-93.
} 
engañadas, en referencia a "su hombre" y no correspondiente a su individualidad--; así, la obra expone mayoritariamente las peripecias que deben sobrellevar para conseguir el dinero que inicialmente era para pagar la fianza del marido y concubino, de la manera que no es complejo -sin que afirmemos que tenga la obligación de serlo- en la exhibición del viaje interior de estas mujeres al concentrarse sólo en sus movimientos externos y poco o nada en sus emociones internas.

Por otro lado, La culta dama y A ocho columnas de Novo, y Una señorita decente de S. Inclán están forjadas en un modelo más melodramático al plantearse un esquema polarizado con respecto a valores positivos y negativos. La protagonista de La Culta dama ${ }^{216}$ es Antonia, mujer adinerada que se dedica a diversos tipos de filantropía que van desde la promoción y el apoyo económico de las bellas artes hasta hogares para adolescentes embarazadas de bajos recursos. En el ámbito social, Antonia es admirada entre las otras damas adineradas. Sin embargo, la obra muestra cómo en su hogar las cosas no son dignas de tal admiración: su esposo sólo se digna a darle el dinero que necesite, siempre y cuando no le mortifique sus rutinas de hombre de negocios; mientras que su hijo Ernesto es de flojo carácter, aunque a su vez realiza actividades nocturnas de dudosa nobleza, lo que evidencia su hipocresía. Por otro lado, Antonia recibe a Eugenia, quien está embarazada, al presentarse con una carta de recomendación de Carmen, amiga de Antonia (ex prometida de Ernesto y su amante fortuito), para que se le dé un cupo en uno de los hogares de maternidad. Más adelante, Carmen - que ha sido desplazada del círculo social de la culta dama- se presenta con Eugenia, su padre y su hijo. Las revelaciones se airean públicamente: en sus escapadas nocturnas, Ernesto sedujo con engaños a Eugenia y la embarazó sin enterarse, porque desapareció y siguió con su vida de joven aristócrata; se resalta que Carmen es amante de Ernesto,

\footnotetext{
${ }^{216}$ Salvador Novo, La culta dama, Grupo Editorial Gaceta, México, pp. 199-288. En una nota que sigue al dramatis personae, suponemos que del autor, se lee: "Los hechos representados en esta comedia son imaginarios". $\mathrm{Al}$ respecto, anotamos que la lectura de la obra no refleja la condición cómica, en la expresión más pura de la risa, y nos preguntamos si acaso Novo simplemente no quería, como señala Monsiváis, lanzar una mofa con la expresión "culta dama" a las señoras de sociedad en medio de la era cardenista, puesto que la obra ataca los prejuicios clasistas (En Carlos Monsiváis, Salvador Novo. Lo marginal en el centro, ERA, México, 2004, p. 184).
} 
y la falsedad del arreglo matrimonial de Ernesto con una hija de una amiga de su madre queda manifiesto. En un principio, la culta dama expulsa a Carmen y a Eugenia de su residencia, ofreciendo un precio para quedarse con la custodia de su nieto. Pero, ante el reclamo de su hijo por no brindarle una vida normal, con calor humano y procesos corrientes a los de cualquier niño sin distingo de clase social, Antonia contrasta su falta de amor filial con las exigencias sociales y opta por redimirse y recuperar el cariño de su hijo y construir una familia con Eugenia y su nieto.

El arrepentimiento de Antonia me impide determinar que la obra se pueda analizar bajos los parámetros de la pieza, pues es poco el desarrollo de los conflictos internos del personaje de acuerdo con su contexto, y, en cambio, los giros dramáticos son grandilocuentes aconteceres (un hijo oculto, una amante y un desacuerdo matrimonial que salen a la luz pública), peripecias bastante fuertes que no llevan a que los personajes tomen conciencia de sus realidades, las de siempre, sino que se presentan como hechos extraordinarios que los llevan a procurar cambiar sus destinos -especialmente el de una Antonia más humanizada y menos preocupada de su imagen social. También hay un velado juego de valores, muy propio del melodrama, en que los personajes pobres encarnan de manera irreductible la ignorancia, lo bueno y lo noble mientras que las elites son desalmadas, hipócritas y sin corazón; en ese sentido, no hay una exploración paulatina en los conflictos internos de Antonia, ni de ninguno de los otros personajes, sino que el clímax de éstos se presenta sólo en un momento muy alto de la obra, en que manifiestan sus emociones en un tono altisonante.

De esa misma manera se desempeña Una señorita decente, ${ }^{217}$ de Federico S. Inclán. En 1915, el triunfo de la revolución en un pueblo del Norte lleva a que doña Encarnación, ex

\footnotetext{
${ }^{217}$ Según Luis Mario Moncada en http://reliquiasideologicas.blogspot.mx/2010/01/i.html, entrada del cuatro de enero de 2010 y consultado en noviembre de 2012, y en donde aloja el Diccionario Histórico del Teatro en México 1900-1950 que formaba parte de una investigación realizada entre 1995 y 1997 bajo la denominación de Sistema de Información del Teatro en México (Sitmex) y que no llegó a publicarse, Un señorita decente al 2010 no se había
} 
hacendada de abolengo, negocie con el líder revolucionario la liberación de su hijo casándolo con su hija Mariana. Tal líder es Amado, un antiguo empleado de Encarnación, que desde la niñez se encargaba de ayudar a Mariana en actividades ecuestres. Amado es recordado como un "indio" que recorría grandes distancias para ir a la escuela y por ser dócil y diligente; realmente no quiere ejecutar a su otrora amo, pero el mando militar así lo obliga a menos que alguna línea familiar le impida llevar a cabo tal tarea, es por eso que aprovechando la situación y avivando un ilusorio enamoramiento de Mariana propone el trato a Encarnación. Mariana, por su parte, es consciente de su encrucijada: sabe que negándose es responsable indirecta de la muerte de su hermano, pero aceptando aplasta el destino manifiesto que le corresponde como señorita decente y de alcurnia.

Posteriormente, Encarnación y Mariana aceptan, y el matrimonio se efectúa, pero en la noche de bodas Mariana le recalca su posición social a Amado y le recuerda sus orígenes pobres y faltos de cuna y cultura, se da una fuerte discusión en la que Amado le recuerda que, de haberlo querido, se la habría robado como le correspondería por derecho de victoria revolucionaria. El matrimonio no se consuma, y Amado se va por siete años; técnicamente, Mariana hubiera podido deshacer la unión, aceptar los cortejos de Salvador, uno "de su misma clase" venido a menos y compañero del ejercicio docente, y mejorar su condición económica y la de su mamá puesto que, después de que se fue Amado, le tocó trabajar y vivir como profesora. Pero en esos siete años se sabe que Amado va en ascenso como general de la revolución, ha permanecido en Europa por un largo tiempo y suena para ministro; asimismo, llegan las noticias de su regreso. En este momento, Encarnación tiene el plan de que Mariana acepte a Amado para poder recuperar su posición social

estrenado. Igualmente, Marcela del Río en Perfil y muestra del teatro de la revolución mexicana tiene un llamado a pie de página en la relación de los textos dramáticos de Inclán que dice: "Algunos textos, tanto de Inclán como de otros autores, aparecen sin fecha porque no se han publicado o porque sólo se han enlistados en diferentes fuentes" (Fondo de Cultura Económica, México, 1997, p. 253). Es el caso de Una señorita decente, de la cual usamos el manuscrito donado en 1988 a la Biblioteca de las Artes, del Centro Nacional de las Artes. Inclán también señaló que la obra es una comedia en tres actos. 
y económica al tener un yerno ministro de la nación, así que se lo propone a su hija. Cuando Amado se presenta se nota que no es el mismo zarrapastroso malhablado y armado que se fue hace siete años, su vocabulario ha crecido, se expresa de mejor manera y tiene un porte más glamoroso, aunque sigue prefiriendo el tequila que el whiskey. Cuando llega el momento de hablar con Mariana, se revelan las verdaderas intenciones de cada uno: Mariana hubiera preferido ser raptada para así odiar por siempre a Amado o para cambiar de circunstancia sin verse involucrada en las decisiones de tal cambio, arrastrada por la violencia revolucionaria, y así despojarse de su rol aristocrático, además, aunque hubiera podido hacerlo, rechazó la posibilidad de deshacer el matrimonio; del otro lado, Amado manifiesta sus prístinas intenciones al decir que, ya que Mariana era la ilusión de su vida, ansiaba ser querido de manera honesta y que ahora que regresa desea que ella lo acepte pues viene con una hija de una mujer que él se había robado como revolucionario. Mariana, al verse amada en buena lid, acepta a Amado y su relación es un triunfo ante los amargos devenires de la guerra.

Una señorita decente expone de buena manera los efectos y defectos de una formación aristocrática y altiva en el personaje de Mariana, pero nuevamente se extrapolan valores como, por ejemplo, que las viejas elites venidas a menos son rencorosas y únicamente les preocupa mantener el statu quo, así como que la revolución sólo tiene intenciones nobles y justas. Un personaje como Salvador es maniqueo, y sus parlamentos van envenenados contra lo que representa la revolución para los que han sido expropiados de sus "derechos"; por su parte, Mariana es una víctima de la "decencia" a quien despojaron de la idea del amor; por otro lado, Francisco, quien es un negociante oportunista, resalta los positivos proyectos de la revolución, lo que se recalca con la postura ecuánime de Amado. Como se ha dicho, ésta es una de las características del melodrama, pues lo que se plantea es una lucha entre el "bien" y el "mal"; nuevamente la expresión de las emociones de los personajes no se da de manera paulatina, sino que explotan, no se contienen, en momentos 
muy precisos. El personaje de Mariana no hace un arco hacia el descubrimiento de su realidad, pues es completamente consciente de ella, sino que por acciones muy fuertes (el casamiento, las intenciones de Amado como esposo y padre) toma decisiones que generan grandes cambios en su destino. Casi se podría concluir que venció el bien sobre el mal. Por último, es curioso que los dos melodramas expuestos anteriormente terminen casi de la misma manera. Antonia en La culta dama, en su parlamento final, cuando se da cuenta del error como madre sobreprotectora y de artificiosa moralidad, dice: “¿Y qué esperamos, corre por mi nieto. $\mathrm{Y}$ tráeme a su madre. Tendré que instruirlo yo. Ya ves que las madres... ¡no saben educar a sus hijos!”. ${ }^{218}$ Mientras que Mariana, al confesar a Amado que todo el orgullo que le impusieron encubrió a la mujer que podía amar y a la pregunta de él de si podría traer consigo a su hija, le dice: “¡Claro que la quiero conocer! ¿Qué esperas? Ya verás como nos entenderemos ella y yo. Le quiero decir que tiene un papá que no comprende a las mujeres...". ${ }^{219}$ Antonia y Mariana son mujeres redimidas, enderezan su camino y cambian drásticamente, algo que la pieza, en términos generales, no contempla como forma genérica.

Por su parte, $A$ ocho columnas $^{220}$ transcurre en la oficina de la secretaría del director del diario El Mundo. De esta obra, Rivera destaca que es una pieza que subsiste en el tiempo y mantendrá su vigencia mientras en muchos países sea actual la corrupción en los medios periodísticos. ${ }^{221}$ En efecto, esta idea es indiscutible, pero no por ello sostenemos su pertenencia al género. Los personajes principales son Celia y Carlos; ella, secretaria del director del periódico, y él, joven periodista en ciernes que se ha estado enamorando de ella. Al gobierno ha llegado un nuevo ministro de salubridad, el doctor Fernández, médico que fue maestro de la escuela de

\footnotetext{
${ }^{218}$ Novo, op. cit., p. 288.

${ }^{219}$ Inclán, op. cit., p 17. El autor reanuda en cada acto la enumeración de las páginas desde uno.

${ }^{220}$ Salvador Novo, A ocho columnas, Grupo Editorial Gaceta, México, 1994, pp. 14-105.

${ }^{221}$ Rivera, op. cit., p.148.
} 
medicina donde Carlos estudiaba antes de que decidiera hacerse reportero, y que ahora planea acabar con el monopolio de la medicina, terminar con la mala administración de los hospitales y organizar la asistencia; por este nombramiento, Carlos tiene la misión de hacerle un reportaje, en lo que sería la primera publicación con su nombre. Sin embargo, después de redactar el reportaje con las propuestas del ministro, Torres, un experimentado reportero, le advierte sobre la posible censura que sufriría su texto puesto que, a sus ojos y obviamente en los términos editoriales del periódico, su texto es laudatorio e imparcial y, ya que se trata de un hecho político, el periódico no puede comprometerse. Detrás de todo esto han estado el Diputado Gómez, el director de El Mundo, y Torres, pues el primero ha estado negociando una campaña desprestigiadora contra el nuevo ministro, y los segundos se supone que ya tienen a Carlos para que haga el trabajo sucio. Como Carlos tiene un profundo respeto hacia el doctor Fernández, además de que le debe la gratitud de haber prestado atención a la enferma madre de Celia, se niega rotundamente, y renuncia al "futuro" que el periodismo corrupto le ofrecía. Así que, al darse cuenta de que su mejor amigo, Enrique, también pretendiente de Celia, acepta la tarea difamatoria, abandona el periódico y se lleva consigo a Celia, quien lo ha preferido pobre pero honesto e íntegro.

Carlos Monsiváis identifica un tono declamatorio en esta obra, "posiblemente el hecho político más comprometido de la obra de Novo. Allí descarga la irritación que su ajetreo social inhibe, y dice lo que piensa de un medio que exprime a sus protagonistas y los abandona en el vacío anímico, en la constancia de la inutilidad”. ${ }^{222}$ Si el final de la obra es que el periódico $E l$ Mundo seguirá actuando como lo ha hecho siempre a pesar del suceso con Carlos, éste definitivamente no lo hará así: su postura es de tal rectitud que se percibe como encarnación de la inocencia, la ilusión, los valores y el buen comportamiento. Igual que los personajes descritos en los melodramas anteriores, no hay una exposición paulatina de las emociones de Carlos; su

\footnotetext{
${ }^{222}$ Carlos Monsiváis, Salvador Novo. Lo marginal en el centro, ERA, México, 2004, p. 186.
} 
trayectoria va con picos muy precisos: el joven que sueña con una carrera en el periodismo, el que golpea al director del periódico y el que renuncia a esa carrera dentro de un afamado periódico. La obra no exhibe cómo Carlos está envuelto en su frustración; al contrario, la enfrenta con valentía; de esa manera, al mantener su integridad, es correspondido por Celia, por lo que la nueva dirección que toma su vida se anticipa llena de nuevas ilusiones, en la humildad, sí, pero en la pletórica felicidad del amor.

Por otro lado, y para pasar a las siguientes obras listadas por Rivera, hay algo que es inherente a todo drama pero que en la pieza es fundamental: la situación inicial es un establecimiento de las relaciones que existen entre los personajes y la relación que éstos tienen con su contexto. Las situaciones iniciales se pueden dar entre personajes que se encuentran por primera vez, personajes que se reencuentra desde hace mucho tiempo, personajes que comparten el cotidiano o una mixtura de las anteriores opciones. Sea cual fuere la alternativa, en este primer momento se nos hace una presentación superficial de la manera como los personajes evalúan y atribuyen un sentido al contexto que viven. Según Erving Goffman: "La información acerca del individuo ayuda a definir la situación, permitiendo a los otros saber de antemano lo que él espera de ellos y lo que ellos pueden esperar de él. Así informados, los otros sabrán cómo actuar a fin de obtener de él una respuesta determinada". ${ }^{223}$ Al definir la situación podemos comprender el modo en que los personajes orientan sus acciones, y, para el caso de la pieza, sus acciones en la vida

\footnotetext{
${ }^{223}$ Ervign Goffman, La presentación de la persona en la vida cotidiana (1959), trad. Hildegarde B. Torres y Flora Setaro, Amorrirto Editores, Buenos Aires, 2001, p. 13. Cabe recordar que en sus trabajos de psicología social, Goffman suele dar un enfoque dramatúrgico a su exposición, como lo plantea en este mismo libro: "El escenario teatral presenta hechos ficticios; la vida muestra, presumiblemente, hechos reales, que a veces no están bien ensayados. Pero hay algo quizá más importante: en el escenario el actor se presenta, bajo la máscara de un personaje, ante los personajes proyectados por otros actores; el público constituye el tercer partícipe de la interacción, un partícipe fundamental, que sin embargo no estaría allí si la representación escénica fuese real. En la vida real, estos tres participantes se condensan en dos; el papel que desempeña un individuo se ajusta a los papeles representados por los otros individuos presentes, y sin embargo estos también constituyen el público" (p. 11).
} 
cotidiana. Cuando un individuo llega a la presencia de otros, comúnmente estos tratan de adquirir información acerca de él o de poner en juego la información que ya poseen, así tratarán de llenar la información correspondiente a su estatus socioeconómico, al concepto que tienen de sí mismos, en la actitud que tiene hacia ellos, su competencia, su integridad, etc.

En el caso de Los frutos caídos, ${ }^{224}$ de Luisa Josefina Hernández, Celia, de veintisiete años, llega de sorpresa, desde la ciudad, a su antigua casa familiar en un ambiente pueblerino, donde se encuentra con su alcohólico, acomplejado y machista tío Fernando; su sumisa esposa Magdalena; la ambiciosa e hipócrita "hija adoptiva" de ellos, Dora, y su solitaria pero comprensiva tía-abuela Paloma. El primer encuentro de Celia es con Dora, donde nos enteramos de que la llegada de Celia es una especial sorpresa. Seguidamente, se encuentra con Magdalena, donde el despliegue informativo empieza a dar forma a los antecedentes y al presente del universo familiar. Nos enteramos de que han pasado 10 años desde la última vez que se habían visto, y que un pleito de familia generó la distancia; que Celia tiene dos hijos de distintos matrimonios, y de esa misma manera, de los prejuicios de Magdalena hacia Celia porque no sabe lo que es un matrimonio de veinticinco años - como el de ella-; que Magdalena, Fernando y Dorita comparten la casa con Paloma, apenas soportada por ser la hermana del abuelo de Celia, quien se ve desplazada a su cuarto como único espacio propio; que la casa no se vendió mientras vivía el padre de Celia para que Paloma viviera allí; que Magdalena y Fernando justifican su estancia al considerarse “administradores" de la casa; que Dora es adoptada; del alcoholismo de Fernando; que Magdalena teme la impresión que tenga Celia de Fernando porque su madre quizá tenga una impresión “exagerada"; que Magdalena no concibe a una mujer embarazada y trabajando en actividades fuera de su hogar. Más adelante, cuando Celia se encuentra con su tía-abuela Paloma también emergen

\footnotetext{
${ }^{224}$ Luisa Josefina, Los frutos caídos, en Teatro mexicano del siglo XX, III, Fondo de Cultura Económica, México, 1956.
} 
los conflictos: Celia cuida a Paloma como una especial encargo de su padre que acata con gusto y esto molesta a Magdalena y compañía; que se espera que Celia no se haya equivocado con su segundo matrimonio, aunque a Paloma eso no le importaría; que Celia ha llegado para vender la casa y ante eso, que no se sabe qué pasaría con Fernando y familia porque apenas si pueden mantenerse.

En tan sólo un trazado superficial, Hernández hace todo un preámbulo lleno de frases cifradas que ya tienen tras de sí cargas significativas que pesan en cada uno de los personajes nombrados. El manejo de la información planteado por Hernández en tan sólo el establecimiento de la situación es denso y revela la importancia en la pieza de los acuerdos en la significación de las situaciones, especialmente acuerdos que siempre están a un filo de su rompimiento. En estas interacciones no sólo descubrimos, como se anotó con Lizárraga, las añoranzas (ilusiones proyectadas hacia el pasado) y anhelos (ilusiones proyectadas hacia el futuro), ambas como dos momentos de inadecuada proyección del deseo (ilusión) y como velos que ocultan la frustración (derrota de los propósitos) de cada uno de los personajes sino, también, el efecto que tienen estos fenómenos en nuestra relación con los demás. Poco a poco, la información que conocemos a través del rifirrafe entre los personajes es asimilada por cada uno de éstos, quienes, en principio, la usarán sin grandes consecuencias -hasta donde la tolerancia lo permite-, para luego convertirlas en armas con las cuales atacarán, especialmente, la integridad emocional de los otros y, aunque no lo quieran, de sí mismos. Si Celia tiene cierto control al ser la dueña de la casa y de las dos huertas que administra Fernando, también es cierto que es susceptible a la impresión que tengan sus familiares de ella y al dominio psicológico de Fernando; y si Fernando y Magdalena temen quedarse sin casa, identifican que lo que más le pesa a Celia es que sus acciones han podido tener consecuencias con las cuales posiblemente ha herido a sus seres más queridos, penas que pesan en 
ella gracias al poder que ejerce sobre su persona el imaginario colectivo de lo que es "ser" una mujer decente.

Más adelante, se dará el encuentro entre Celia y Fernando, a quien vemos por primera vez y quien ya se presenta con predisposición al choque gracias a la información previa que ha recibido de Dora y Magdalena sobre la sorpresiva visita de Celia. Desde el primer saludo, Fernando se encarga de adobar la situación en un tono seco y amargo:

CELIA: ¿Qué tal, Fernando?

FERNANDO: Querida sobrina...

(La abraza delicadamente, sobriamente, casi no la toca)

CELIA: Creo que no debía haber llegado tan de improviso.

FERNANDO: (Sentándose.) ¿Por qué? Llegas a tu casa.

CELIA: Es verdad.

$[\ldots]$

FERNANDO: Lo que más me alegra, Celia, aparte de tenerte aquí, es saber que de nuevo tienes a tu familia constituida.

CELIA: Desde hace tres años.

FERNANDO: Me preocupaba pensar en ti como una mujer sola y con un hijo.

CELIA: Vivía con mi madre

FERNANDO: No tiene importancia, en ese caso. La posición de la mujer sola es dudosa. Los hombres que la conocen no saben qué clase de mujer es hasta que la tratan a fondo, la ponen a prueba.

CELIA: Si eso pasó alguna vez, no me di cuenta.

Falsas formalidades y olvidos voluntarios marcan la dinámica del conflicto. Más adelante, Fernando cuestiona el papel de Celia, recalcando situaciones como la felicidad de Celia, si puede llevar su hogar a gusto, si su marido la puede mantener, señalando que no cree que un segundo esposo pueda querer al hijo de su mujer fruto de la unión en otro matrimonio, en fin, ironizando sobre "la perfecta vida feliz" de Celia. Luego de tal despliegue de sarcasmo, Celia saca sus cartas: llega para vender todo lo que la ata al pueblo, información que, lo sabe, desestabiliza por completo la tranquilidad en la que vivían Fernando y familia. Celia y Fernando han definido una postura incluso desde el momento en que sabrían que se encontrarían, producto de la evaluación que hacen de la situación que permitirá su interacción; tal postura se desarrollará a medida que avanza la obra y ha sido determinada por la manera en que se han presentado los unos a los otros, y que sirve para 
determinar el desarrollo estratégico que llevará a los personajes de la pieza a momentos de crisis en los que después de evaluar a los demás se evaluarán a sí mismos.

Como se espera haber expuesto, Los frutos caídos es una obra donde hay un equilibrio de fuerzas entre los personajes que entran en conflicto, quienes emocionalmente se entrelazan en una disputa por mantener la integridad personal, el yo de cada uno de los personajes. En efecto, las tensiones evidencian que, aunque cada uno podría definir como mejor le parece cada situación, existen diferentes maneras de definir una misma situación (para Dora podría ser untarse de la "glamorosa" visita de una mujer de la capital, para Celia podría ser simplemente unos días de descanso, para Magdalena y Fernando sería el tiempo propicio para pasar unos días con su sobrina más cercana, y sin embargo no es así); al final, lo cierto es que la definición de ese encuentro familiar, como los de cualquier interacción, están permeados por relaciones de poder.

Así, si en Los frutos caídos estás relaciones parecen de tensión equilibradas, en Felicidad, ${ }^{225}$ de Emilio Carballido, la presencia de Mario, el patriarca de los Ramírez, determina casi a su antojo y de manera unilateral la dinámica familiar. Sin embargo, casi tan importante como eso, es que Mario, a su vez, está determinado por la relación que tiene con el dinero y la influencia de éste en su noción de felicidad. En el hogar de los Ramírez siempre ha existido la precariedad económica, no bajo los parámetros de la miseria, pero sí viviendo con préstamos y limitantes, lo que ha convertido a Mario en un ser profundamente amargado. La situación no es desconocida por su esposa, Cuca, su hija, Ofelia, y su yerno, Sergio, pero ellos, a su modo, tratan de llevar el cotidiano tranquilamente, al asumir sin problema sus roles dentro de la familia, arreglándoselas como pueden y tolerando comprensivamente los achaques de Mario. Por otro lado, hay una esperanza de que lleguen dos fuertes sumas de dinero: siete quincenas retrasadas del sueldo como maestro de Mario, y una póliza que ha estado pagando durante veinticinco años y de la que todos esperan que les

\footnotetext{
${ }^{225}$ Emilio Carballido, Felicidad, en Tres comedias, Editorial Extemporáneos, México, 1981, pp. 164-240.
} 
toque una parte para sacarle provecho. Desde esta situación, vemos cómo entre Sergio, Ofelia y Cuca hay una relación horizontal y fraternal:

OFELIA: [...] ¡Veinticinco mil pesos! Ay, lo que yo haría con ese dinero.

CUCA: Bueno, te tocará tu partecita, claro.

OFELIA: ¿Papá te dijo?

CUCA: No, yo pienso, pero es seguro que él...

OFELIA: (Decepcionada). Ya me parecía raro. ¿No ha llegado?

Para Cuca, madre de Ofelia, parece obvio que su esposo, apenas reciba el dinero de la póliza, compartiría los beneficios con la familia de la misma manera que han compartido las vacas flacas. También Sergio cree que su suegro le podría hacer un préstamo para montar una botica y comparte esta ilusión con su suegra y su esposa, mas Ofelia conoce tan bien a su padre que no espera nada de él. Así, el efecto del deseo de dinero y su correspondiente consecuencia, la supuesta anhelada felicidad, se refleja en que en la casa no se puede escuchar radio ni mantener luces encendidas de más porque gastan energía, en que Mario viste siempre la misma ropa propia de la escasez, no tiene amigos para evitar despilfarrar al reunirse con ellos, jamás da un presente o un cumplido a su esposa y lo único que quiere hacer cuando llegue el dinero es guardarlo. Más adelante, las quincenas atrasadas llegarán gracias a que Mario conoce a una “señorita”, Emma, que puede agilizar los pagos en la oficina de hacienda. Cuando esto sucede, el desarreglado maestro empieza a preocuparse por su apariencia, hace bromas, hace halagos a su hija y se permite comer en restaurantes: además, a partir de la llegada del dinero, Mario empezó a frecuentar a Emma, quien recibe los cumplidos y se deja seducir por el bonachón profesor, creyendo que éste es viudo. Desde el encuentro entre Mario y Emma, en el hogar se horizontalizan parcialmente las relaciones, consecuencia de la alegría de la llegada del dinero y del buen humor del profesor, aunque esto no se refleje en términos económicos para los demás integrantes de la familia, mucho menos en el tema del préstamo a Sergio y Ofelia. Por otra parte, la relación entre Emma y Mario es un tire y afloje que consiste en que Mario quiere 
complacerla, y ella quiere que él se comprometa seriamente en matrimonio. Todo este proceso lo vemos a través del cómico tono de las reacciones y los volubles estados emocionales de Mario, quien al verse descubierto en el doble engaño se da cuenta de que con el dinero no llegó la tan anhelada felicidad por años. Este momento es de frustración, pero también de autorreconocimiento por parte de Mario, pues descubre que siempre estuvo determinado por la ilusión de tener holgura económica para así proyectar su relación con los suyos: su paciente, comprensiva y amorosa esposa; su solidaria hija; la amistad de su yerno; mientras no tuvo el dinero, sustentaba su autoridad de maestro gruñón en las quejas de una vida austera, y cuando al fin el dinero llegó a sus manos, su autoridad ante la traicionada confianza cae en picada: por supuesto, la esperada felicidad, su noción de felicidad, no se hace presente como se esperaba.

La ilusión de felicidad sustentada en la llegada del dinero es tan fuerte que dirige las relaciones de Mario dentro de su hogar y por fuera de él. El profesor es dos personas en una que se divide, primero, en un antes y después de los pagos de las quincenas; y luego, en uno que en su hogar es el respetado y tacaño profesor, y que con Emma se comporta como un generoso adolescente enamorado. En Felicidad, Mario no tiene una contraparte que le haga equilibrio a sus acciones, genera el conflicto consigo mismo, pues el conflicto no es que lo descubran en sus amoríos, sino ese infinito egoísmo producto de la ilusión de poseer dinero. La manera en que las ilusiones y las frustraciones atraviesan al individuo otorga poder a un elemento no encarnado en otro individuo que también desempeña un rol para determinar las situaciones. Esto es: un macrocontexto caracterizado por los imaginarios colectivos que cargan con las ideologías imperantes y que, como es el caso de Mario, determinan los sueños y las ilusiones de cada individuo y, de esa manera, su relación con los otros. De lo que se puede concluir que lo peor de ese macrocontexto es que, si no viene encarnado en otro individuo, lo más probable es que 
seamos nosotros mismos quienes lo encarnemos y representemos. Mario y Celia son ejemplos de ese poder.

El resumen de las dos obras que hasta ahora se han hecho han tenido como parámetro la definición de la situación y las relaciones de poder que emergen en ellas. El escenario donde emergen está formado por las interacciones cara a cara, entendidas éstas, según Goffman, "como la influencia recíproca de un individuo sobre las acciones del otro cuando se encuentran ambos en presencia física inmediata. Una interacción puede ser definida como la interacción total que tiene lugar en cualquier ocasión en que un conjunto dado de individuos se encuentra en presencia mutua continua". ${ }^{226}$ En esta interacción, sin embargo, dirá Édison Gastaldo, uno de los dos interactuantes, que puede ser otro individuo o un contexto, define "legítimamente" lo que está sucediendo o lo que alguien es, en ese sentido: "Las relaciones de poder existen en la medida en que algunas definiciones de situación son más legítimas que otras, y esa legitimidad es resultado de quien tiene el poder de proponer y sustentar la definición". ${ }^{227}$ Nuestra hipótesis es que la pieza como género dramático es una estética que exhibe la manera cómo es afectado el sujeto preso de esas dinámicas y la manera cómo reacciona ante ello.

Así, una equivocada manera de interpretar la situación, es decir, cuando alguien actúa o habla como si estuviese en el lugar apropiado, dice Gastaldo apoyado en Goffman, nos expone al poder de la culpa y la vergüenza, las cuales son formas de cohesión social, presentadas como formas de temor al ridículo para evitar castigos indirectos: "En la vida cotidiana, no

\footnotetext{
${ }^{226}$ Goffman, op. cit. p. 27.

${ }^{227}$ Édison Gastaldo, Goffman e as relações de poder na vida cotidiana, Revista Brasileira de Ciências Sociais, vol. 23, núm. 68, octubre, 2008, p. 150.

Consultado en http://redalyc.uaemex.mx/src/inicio/ArtPdfRed.jsp?iCve=10713666017\#. En 31/10/2012. La traducción es mía.
} 
necesitamos de soldados armados o fiscales con talonarios de multas para ir a lugares donde no queremos, conversar con personas que no gustamos, o hablar de cosas que no creemos". ${ }^{228}$

Es de esa manera como se comportan María Luisa Santoveña y su hermana Luz María, personajes de la obra de Antonio González Caballero, Señoritas a disgusto. ${ }^{229}$ Dichas damas, huérfanas sobreprotegidas de aproximadamente 31 y 29 años respectivamente, esperan ser cortejadas, acorde a las estrictas costumbres de su pueblo, por el hombre de sus sueños. Mientras esperan que alguien rente uno de los cuartos de su casa para ayudarse económicamente, las conversaciones entre las jóvenes, los sueños que se complacen alimentar la una a la otra, se refieren a ese caballero que podría llegar para hacerlas sentir las delicias del amor: "Será alto, moreno y bien parecido a más no poder", dice Luisa; "Ojos verdes y bigote recortado...", la complementa María; "Y al vernos, se quedará prendado de una de nosotras... no, no, ¡de las dos!", recalca Luisa. Han deseado tanto ser amadas y casarse que la edad que tienen y el estricto examen del pueblo las llenan de miedos con respecto a la soledad y la posibilidad de no poder conformar una familia. Cuando por fin llega Luis, un galante joven contador proveniente de la ciudad, la situación se define con el doble mensaje propio de la moral y de las ilusiones de las jóvenes:

LUISA: Le advierto que ésta no es una casa de huéspedes propiamente dicha, sino que deseamos ayudarnos un poco, usted sabe (con timidez), somos huérfanas y... solas. Supongo que vendrá con su esposa.

JOVEN: (Parándose de nuevo) No, soy soltero.

LUISA: (Sentándose) ¡Soltero! Así que... usted lo quiere para usted solo. (Su hermana se coloca detrás).

JOVEN: Naturalmente. ¿Entonces para quién iba a ser?

LUISA: (Confidencial) Pues aquí en el pueblo observamos costumbres muy rigurosas. ¡Pero siéntese usted! (Se sienta el joven)

JOVEN: Gracias.

LUISA: Muy tradicionales si usted quiere, pero qué le vamos a hacer. (Lo mira con mirada de inteligencia. Silencio)

\footnotetext{
${ }^{228}$ Ibid., p. 151.

${ }^{229}$ Antonio González Caballero, Señoritas a disgusto, libreto del fondo especial de la biblioteca del Centro Nacional de las Artes, 1983.
} 
JOVEN: (Sin saber a dónde conduce la plática) Pues, sí; qué le vamos a hacer. (Sonríe forzadamente.)

LUISA: (Molesta al no ser comprendida y tener que ser más clara) El caso es que no sé lo que va a pensar la gente.

JOVEN: (Aún sin comprender) No, nadie sabe lo que va a pensar otro... (Silencio) Si acaso los adivinos, y eso... (Sonrie, pero encuentra una mirada dura.)

LUISA: Como le dije antes (Recalcando), somos mi hermana y yo solas con la sirvienta... somos mujeres todas... muy estrictas y... iy solteras!

Pero las implicaciones de la ilusión de que un gallardo caballero se case con ellas son vividas por las jóvenes Santoveña de distinta manera. Mientras Luisa, a la menor señal de un comentario particularmente libidinoso, evidencia y maximiza sus represiones, María da riendas suelta a esa imaginería. Esta disparidad en los anhelos de las hermanas marca la manera como ellas asumirán la llegada de Luis, pues ambas creen que se han enamorado de él (más que enamoramiento parece desesperación), y por primera vez tienen una disputa que las hace enojarse la una con la otra. Pero como han alcanzado tal nivel de represión, la lectura equivocada que ambas hacen de la situación -se creen correspondidas al no tener la capacidad de diferenciar entre el cortejo y la amabilidad de Luis- lleva a consecuencias desastrosas, principalmente porque el duro conservadurismo del pueblo llega a través de ellas mismas: en un hogar de mujeres decentes es mal visto convivir, así sea de huésped y para poder sobrevivir, con un hombre joven y soltero; la edad que tienen ya las hace aspirantes a la soltería de por vida; el deseo físico por un hombre es estar en pecado: “¡Dios nos perdone! ¡Estamos en pecado! ¡Qué difícil es amar y ser pura", dice sollozante Luisa después de sentir que debe matar sus propios malos pensamientos. Así, el final de la obra se presenta devastador para las dos jóvenes. En la celebración del cumpleaños de Luis, cuando estaban en el clímax ilusorio de la correspondencia amorosa y el desaire de sus amigas del pueblo se hace hipócritamente evidente, el joven contador les anuncia que se casará con la hija de su jefe. 
En consecuencia, María tiene el desliz de hacer una escena de celos y pinta un cuadro de mísera soledad ante un perplejo Luis; pero María, más preparada para enfrentar los desajustes entre las ilusiones y la realidad, salva la situación al aplaudir a su hermana y convertir el sincero sufrimiento en una artificiosa escena teatral: "Bravo hermanita mía, ¡Tus imitaciones de actrices del cine son geniales! Creyeron que estaba hablando en serio y no actuando", dice. Posteriormente, las dos hermanas no vuelven a ver jamás a Luis, a causa de que su prometida se los prohíbe. Por su parte, María, quien decide no quedarse envejeciendo en esa casa sin vivir la vida -quizá no cómo lo anhelaba, pero si por lo menos vivirla-, se va con un joven de un circo y abandona a su hermana. Luisa, ante la inminente soledad, ante la idea de ser objeto de examen de todo el pueblo por tener una hermana que se escapó con un hombre o por su imagen de solterona y, por ende, de potencial amante para cualquiera de los esposos de las demás mujeres, acepta por fin las pretensiones de matrimonio de Silvestre, un viejo amigo de la casa, quien también pretendió a su madre y al que no calificaba por debajo de viejo verde. Luisa parece haber llegado a un final feliz, pero lo cierto es que acepta casarse porque no le queda más opción. Silvestre se va feliz a empezar los preparativos de la boda, y ella se queda sola, sin saber qué hacer y leyendo la letra de un vals amoroso que al terminar le provoca un llanto inconsolable ante el dolor de una vida que continuará igual pero con la implacable conciencia de la frustración.

Las tres obras comentadas hasta este momento dan algunas pistas de elementos que les son constantes y que tienen que ver con la manera como los personajes son presionados para cumplir con ciertas reglas o conductas morales. Por un lado, las dificultades económicas aparecen para iluminar las insatisfacciones de los personajes. Celia, en Los frutos caídos, quiere vender la casa que heredó de su padre para poder aliviarse de todas las responsabilidades económicas que enfrenta, sin embargo, se da cuenta de que es más parecida y está más unida a 
sus familiares de lo que cree; Mario, en Felicidad, evidencia que su frustración ha sido la de vivir en una espera innecesaria, olvidando vivir a gusto con lo que lo rodea; y el problema económico de Luisa y María evidencia la falta y el deseo por un esposo proveedor que las ame como mujeres. Por otro lado, los roles femeninos son víctimas de los abusos morales de la época que determinan a qué edad deben casarse, cómo comportarse como esposas, evitar el divorcio, satanizar la soltería, o cómo concebir el amor y su directa asociación al matrimonio: mientras Emma, en Felicidad, dice a Mario tener treinta años para parecer más doncella, cuando en realidad tiene treinta y nueve, Cuca da su lugar al cacique Mario y ni se cuestiona la infidelidad de su marido; Luisa y María son víctimas que concentran todo lo anteriormente nombrado; y Celia, para poder mantener su integridad, debe soportar y lidiar con los estigmas de no ceñirse al pie de la letra a las reglas que impone la sociedad. De estas dos situaciones se puede vislumbrar en las obras el cumplimiento de una de las principales características de la pieza: reflejar los niveles de insatisfacción de los personajes con su realidad.

Los personajes de la pieza son víctimas de su contexto, encarnado, como se dijo antes, en los otros o en nosotros mismos. Lo cual, como representación estética, no es gratuito a nivel histórico, pues los conflictos que se exponen en una pieza tienen que ver con la manera en que el poder -refiriéndonos al poder en dimensiones macroestructurales-, ha creado una microfísica en la que, como dispositivo, es ejercido por cada uno de los individuos de la sociedad, lo que genera una vigilancia constante y despliega una presencia espesa en todas las dimensiones de la interacción social.

En el capítulo I de esta investigación nos propusimos exponer las grandes transformaciones acaecidas entre los siglos XVIII y XIX que llevaron a cambios políticos, económicos, sociales e individuales que dieron la posibilidad a que una nueva practica textual, como la pieza, diera su aparición. Brevemente señalamos que, para Michel Foucault, con el 
advenimiento de la Burguesía, se instauró un "régimen por así decir sináptico del poder, de su ejercicio en el cuerpo social. No por debajo del cuerpo social", que ha permitido cambios en la estructura fundamental de los pequeños ejercicios del poder. ${ }^{230}$ Foucault apunta que la coyuntura que llevó a estos cambios se debe, principalmente, a que en el siglo XVIII hubo un gran impulso demográfico que aumentó la población de las ciudades (a conveniencia de las aspiraciones antinomadistas que el estado necesitaba); de esta manera, se dieron cambios en la escala cuantitativa de grupos a los que había que controlar o manipular (multiplicación de la población escolar, de la hospitalizada, del ejército en tiempos de paz); ${ }^{231}$ y, "otro aspecto de la coyuntura, es el crecimiento del aparato de producción, cada vez más extenso y complejo, cada vez más costoso también y cuya rentabilidad se trata de hacer crecer”. ${ }^{232}$ Ante esto, la burguesía se vio entregando su capital (materias primas, maquinaria, instrumentos) en manos de la clase popular para que la trabajara, así que fue absolutamente necesario proteger esa riqueza:

Porque la sociedad industrial exige que la riqueza esté directamente en las manos no de quienes la poseen sino de aquellos que permitirán obtener beneficios de ella trabajándola. ¿Cómo proteger esta riqueza? Mediante una moral rigurosa: de ahí proviene esta formidable capa de moralización que ha caído desde arriba sobre las clases populares del siglo XIX. Observad las formidables campañas de cristianización de los obreros de esta época. Ha sido absolutamente necesario constituir al pueblo en sujeto moral. ${ }^{233}$

Con el desorden y la confusión generada por la aglomeración de la población en los destinos que la burguesía les había asignado -los colegios, las fábricas, la milicia, los hospitales

\footnotetext{
${ }^{230}$ Michel Foucault, Entrevista sobre la prisión: El libro y su método (1975), en Microfísica del poder, trad. Julia Varela y Fernando Alvarez-Uría, Las Ediciones de La Piqueta, Madrid, 1992, p. 97. Recordemos que Foucault rechazaba la construcción de una historia lineal, así, en la misma página, señala: "Todo el mundo conoce las grandes transformaciones, los reajustes institucionales que han hecho que cambiase el régimen político, la manera como han sido modificadas las delegaciones de poder en la misma cabeza del sistema de Estado. Pero cuando pienso en la mecánica del poder, pienso en su forma capilar de existencia, en el punto en el que el poder encuentra el núcleo mismo de los individuos, alcanza su cuerpo, se inserta en sus gestos, sus actitudes, sus discursos, su aprendizaje, su vida cotidiana".

${ }^{231}$ No lo señala Foucault, pero recordemos que la población de las fábricas y de las industrias también creció.

${ }^{232}$ Michel Foucault, Disciplina, en Vigilar y castigar, nacimiento de la prisión (1975), trad. Aurelio Garzón del Camino, Siglo XXI Editores, México, 1996, p. 221.

${ }^{233}$ Foucault, Microfisica, p. 99.
} 
o las cárceles-, se hizo necesaria la instalación de controles. Así, la vigilancia pasó a ser un operador económico decisivo puesto que es "a la vez una pieza interna en el aparato de producción y un engranaje especificado del poder disciplinario". ${ }^{234}$ Tomando modelos del ejército o del hospital, el individuo es vigilado, primero, en el colegio: control del tiempo de llegadas, salidas y descansos, se lleva un historial escrito de los alumnos, se organizan de manera que puedan ser vistos por el profesor, se uniforman, se estimula la denuncia, se registran las buenas o las malas conductas. Y posteriormente es vigilado en las fábricas de manera análoga: se marcan tarjetas de entrada y salida que controlan el cumplimiento del horario laboral, se vigila que el tiempo no se gaste inútilmente, constantemente se inspecciona a todos los obreros, se amenaza a los trabajadores con informar de conductas indebidas a los jefes, etc. La vigilancia a través de las disciplinas intenta, según Foucault, definir una táctica de poder sobre las multiplicidades que básicamente responde a tres criterios: hacer económicamente lo menos costoso posible el ejercicio del poder; ser lo más efectivo que se pueda alcanzando su máxima intensidad y extendiéndose lo más lejano posible con éxito; ligar el crecimiento "económico" del poder y el rendimiento de los aparatos en el interior de los cuales se ejerce (ya sean los aparatos pedagógicos, militares, industriales, médicos). En suma, concluye Foucault, "aumentar a la vez la docilidad y la utilidad de todos los elementos del sistema". ${ }^{235}$

Anteriormente, uno de los cimientos de la evidencia del poder era su presencia física, la imponente pesantez, su tangible corporalidad, lo que se convertía en su fundamento operativo: el criminal ajusticiado en plaza pública, los monumentos y las presencias majestuosas de soberanía, los rituales públicos como las coronaciones ante el pueblo, la impartición de justicia en tribunales abiertos, las exhibiciones de derroche y capricho de los amos, el vasallaje como

\footnotetext{
${ }^{234}$ Foucault, Vigilar y castigar, p. 180.

${ }^{235}$ Ibid., p. 221.
} 
relación de sumisión extremadamente codificadas, la vigilancia al dominio del trabajo en la tierra más que en los individuos, el control de los cuerpos en masa (como la esclavitud y los encierros durante la peste) o las prisiones de gruesos muros y poca luz que necesitaban un alto número de vigilantes por cierto número de prisioneros. Después del siglo XVIII se ha podido constituir un saber sobre el cuerpo para dominarlo a partir del conjunto de una serie de disciplinas escolares y militares. Así, la disciplina fabrica, a partir de los cuerpos que controla, una individualidad que está dotada de cuatro características: "es celular (por el juego de la distribución espacial), es orgánica (por el cifrado de las actividades), es genética (por la acumulación del tiempo), es combinatoria (por la composición de fuerzas)”. ${ }^{236}$ Igualmente, para garantizar la combinación de estas fuerzas dispone de cuatro grandes técnicas: construye cuadros; prescribe maniobras; impone ejercicios; despliega tácticas. De estas cuatro, Foucault destaca a la táctica por ser la forma más elevada de la práctica disciplinaria, pues es el "arte de construir, con los cuerpos localizados, las actividades codificadas y las aptitudes formadas, unos aparatos donde el producto de las fuerzas diversas se encuentra aumentado por su combinación calculada". 237

Para Foucault, si se piensa en la guerra como una continuación de la política, entonces la política ha sido concebida como la continuación de la guerra en lo que respecta al modelo militar como mecanismo para prevenir la alteración civil; como técnica de la paz y del orden internos la política, ha tratado de utilizar el dispositivo del ejército perfecto, de la masa

\footnotetext{
${ }^{236}$ Ibid., p. 172.

${ }^{237}$ Id. Para J. A. De Guibert y para P. Joly, citados por Foucault, la táctica es la ciencia de la guerra "ya que enseña a constituir las tropas, a ordenarlas, a moverlas, a hacerlas combatir; puesto que ella sola puede suplir el número, y manejar la multitud; incluirá, en fin, el conocimiento de los hombres, de las armas, de las tensiones, de las circunstancias, ya que son todos estos conocimientos reunidos, los que deben determinar dichos movimientos" y además, "da la idea de la posición respectiva de los hombres, que componen una tropa cualquiera de la de las diferentes tropas que componen un ejército, de sus movimientos y de sus acciones, de las relaciones que tienen entre ellas.
} 
disciplinada, de la tropa dócil y útil, del regimiento en el campo y en los campos. ${ }^{238}$ Así, si hay una serie política-guerra que pasa por la estrategia, hay una serie ejército-política que pasa por la táctica.

Es la estrategia la que permite comprender la guerra como una manera de conducir la política entre los Estados; es la táctica la que permite comprender el ejército como un principio para mantener la ausencia de guerra en la sociedad civil.[...] Los historiadores de las ideas atribuyen fácilmente a los filósofos y a los juristas del siglo XVIII el sueño de una sociedad perfecta; pero ha habido también un sueño militar de la sociedad; su referencia fundamental se hallaba no en el estado de naturaleza, sino en los engranajes cuidadosamente subordinados de una máquina; no en el contrato primitivo, sino en las coerciones permanentes; no en los derechos fundamentales, sino en la educación y formación indefinidamente progresivos; no en la voluntad general, sino en la docilidad automática. ${ }^{239}$

De esta manera, la disciplina organiza un espacio analítico, en donde logra conocer y dominar el uso de la fuerza del cuerpo como fuerza "política" y que, además, lo maximiza como fuerza útil: establece las presencias y las ausencias, sabe dónde y cómo encontrar a los individuos, instaura las comunicaciones útiles, interrumpe las que no lo son, vigila en cada instante la conducta de cada cual, la aprecia, la sanciona, mide las cualidades o los méritos. ${ }^{240}$ Las consecuencias de esto son que, dirá Foucault, la disciplina "fabrica" individuos al funcionar como un enderezador de conducta sin llegar a excesos, pues es un poder modesto, suspicaz, que funciona según el modelo de una economía calculada pero permanente. En efecto, el éxito del poder disciplinario se debe al uso de instrumentos simples: la inspección jerárquica, la sanción normalizadora y su combinación en un procedimiento que le es específico: el examen. En este punto, Foucault y Goffman confluyen en la misma vertiente; mientras Goffman habla de que las definiciones de las situaciones y las interacciones están mediadas por las relaciones de poder entre los interactuantes, Foucault dirá respecto al examen que: "El ejercicio de la disciplina supone un dispositivo que coacciona por el juego de la mirada; un aparato en el que las técnicas

\footnotetext{
${ }^{238}$ Ibid., pp. 172-173.

${ }^{239}$ Ibid., pp. 173-174.

${ }^{240}$ Ibid., p. 147.
} 
que permiten ver inducen efectos de poder y donde, de rechazo, los medios de coerción hacen claramente visibles aquellos sobre quienes se aplican". ${ }^{241}$ De esta manera, en el centro de todos los sistemas disciplinarios funciona un pequeño mecanismo penal que beneficia con cierto privilegio de justicia, con sus propias leyes, sus delitos especificados, sus formas particulares de sanción, sus instancias de juicio:

En el taller, en la escuela, en el ejército, reina una verdadera micropenalidad del tiempo (retrasos, ausencias, interrupciones de tareas), de la actividad (falta de atención, descuido, falta de celo), de la manera de ser (descortesía, desobediencia), de la palabra (charla, insolencia), del cuerpo (actitudes "incorrectas", gestos impertinentes, suciedad), de la sexualidad (falta de recato, indecencia). Al mismo tiempo se utiliza, a título de castigos, una serie de procedimientos sutiles, que van desde el castigo físico leve, a privaciones menores y a pequeñas humillaciones. ${ }^{242}$

En Con la frente en el polvo, ${ }^{243}$ de Luis G. Basurto, vemos la manera como el castigo disciplinario se mueve fluctuante a través de la jerarquía eclesiástica y de las autoridades morales de los hombres. Un obispo a punto de ser nombrado cardenal se presenta como penitente en el mísero cuarto de su antiguo profesor del seminario. Agustín, el obispo, necesita confesarse y el humilde cura es la única autoridad a la que considera digna de tal papel. En principio, el viejo cura Terencio acata las formalidades jerárquicas, pero en varios destellos se recupera la autoridad de aquel profesor que reprendía al joven Agustín. Llegado el momento, Agustín confiesa sus pecados: desde niño se obsesionó con la idea de alcanzar el poder de Dios, por lo que empieza una carrera para llegar a cardenal. Durante esa carrera, mandó, sin importarle la pobreza a que lo condenaba, a Terencio a la iglesia donde predica; se convirtió en un hipócrita administrador espiritual para quien la caridad no era una más que un requisito para alcanzar sus metas, y la bondad, una forma de distribuir el poder a su gusto: "toda mi carrera eclesiástica y hasta mi conducta de hombre, han sido una simulación y una mentira", confiesa

${ }^{241}$ Ibid., p. 175.

${ }^{242}$ Ibid., p. 183.

${ }^{243}$ Luis G. Basurto, Con la frente en el polvo, en Teatro de Luis G. Basurto, Editores Mexicanos Unidos, México, 1986. 
Agustín. Pero el obispo guarda dos secretos que lo atormenta mucho más. En primera instancia, siempre le tuvo un infinito odio y rencor a su madre, quien lo abandonó con su padre por irse con otro hombre cuando él era niño; cuando ésta lo busca para pedir que la perdone, él no es capaz de mantener su hipócrita integridad moral como jerarca de la Iglesia y le niega el perdón a su madre, quien muere sola en un asilo. Por otro lado, el odio a su madre hizo que odiara a otras mujeres, así que castiga y humilla fuertemente a una mujer que, siendo maltratada en su hogar, se apasiona con el servicio a Agustín provocando que avivara en él las debilidades carnales del hombre: "el más abyecto de todos los pecados". Aunque sofoca sus instintos sexuales, Agustín se acusa del pecado de "asesinato de amor" y por haberla expulsado de su templo "negándole la absolución". Después de haber provocado severos castigos, como hombre y como obispo, Agustín quiere, a través de Terencio, castigarse a sí mismo, situación que se agudiza cuando descubre que su maestro fue consultado para elegirlo como cardenal: "Y lo elegí, no por su virtud, no por su celo apostólico que resplandece en este momento ante mis ojos, sino por la soberbia de humillarme, de doblegarme ante el cura más torpe, más corto de luces de cuantos hay en mis parroquias".

En Con la frente en el polvo se castiga la sexualidad y el abandono del hogar, no de manera punitiva, sino castigando la integridad de las personas que comenten la penalidad. Se supone que un obispo estaría en capacidad y obligación de ofrecer el perdón, pero la madeja psíquica de Agustín revela su humanidad, aquella que había aplacado con el fin de ascender no sólo dentro de las jerarquías de la iglesia, sino en su meta de igualarse a Dios. La disciplina de los hombres se instala en Agustín como se instala en cualquier otro individuo que active los mecanismo de las micropenalidades para castigar, ya sean las libertades femeninas que se salen de las morales impunemente establecidas, o la manera en que también se castiga un retraso temporal, una palabra mal dicha, un gesto indecente o una descortesía. El mecanismo de la 
pieza en la obra de Basurto opera a través de la larga confesión de Agustín, la cual evidencia en la relación de poder establecida entre Terencio y Agustín las ironías de la vida: que no es necesaria una estatura moral e integra para alcanzar los más altos niveles de poder en una institución que se cree poseedora de la más alta autoridad moral. El arrepentimiento de Agustín no es suficiente sin el perdón que su propia madre le hubiera podido dar. Tampoco es suficiente el paroxismo de su confesión para que las cosas cambien, pues, al separarse de Terencio, el devenir eclesiástico continuará de la misma manera que el instante antes en que el obispo cruzó la puerta del cuarto de Terencio en busca de la absolución.

Con la frente en el polvo evidencia que el castigo en un régimen disciplinario supone una doble referencia jurídico-natural: por un lado un "orden artificial", "dispuesto de manera explícita por una ley, un programa, un reglamento; por el otro, es también un orden definido por unos procesos naturales y observables". ${ }^{244}$ Así, el castigo disciplinario es el fantasma de la venganza de la ley, provoca el arrepentimiento y encauza las conductas; también es un elemento doble en su sistema pues otorga gratificación y sanción:

$\mathrm{Y}$ es este sistema el que se vuelve operante en el proceso de encauzamiento de la conducta y de corrección.[...] Este mecanismo de dos elementos permite cierto número de operaciones características de la penalidad disciplinaria. En primer lugar la calificación de las conductas y de las cualidades a partir de dos valores opuestos del bien y del mal; en lugar de la división simple de lo vedado, tal como la conoce la justicia penal, se tiene una distribución entre polo positivo y polo negativo; toda la conducta cae en el campo de las buenas y de las malas notas, de los buenos y de los malos puntos. ${ }^{245}$

Las implicaciones de esta observación se ven reflejadas en los universos que propone la pieza, no a la manera del melodrama que encarna los valores positivos o negativos sin espacio a los matices en sus personajes, sino en el contexto o quien lo represente. Las escalas de valores de la pieza suelen plantearse en esta cuantificación, en la jerarquización producto de los

\footnotetext{
${ }^{244}$ Foucault., Vigilar y castigar, p. 184. De allí los posibles calificativos de justos o injustos.

${ }^{245}$ Ibid., p. 185.
} 
aparatos disciplinarios que relaciona a unos con los otros en términos de buenos y malos, pero no para abanderar campañas aleccionadoras, sino para mostrar los efectos de esta arbitraria partición. Es de esa manera como las disciplinas fabrican sujetos morales: logrando operar en los individuos mismos. La consecuencia es que cada personaje o individuo defenderá su verdad basado en los estándares de normalidad que han tenido a bien adquirir. Así, dirá Foucault, "la vigilancia, y con ella la normalización, se torna en uno de los grandes instrumentos de poder al final de la época clásica. Se tiende a sustituir o al menos a agregar a las marcas que traducían estatutos, privilegios, adscripciones, todo un juego de grados de normalidad, que son signos de adscripción a un cuerpo social homogéneo", porque el poder de normalización obliga a la homogeneidad. Aunque da espacio a las individualizaciones al permitir las desviaciones, determinar los niveles, fijar las especialidades y hacer útiles las diferencias ajustando unas a otras, ${ }^{246}$ no es difícil intuir que la característica de la normalización binaria a la que todos los individuos, o los personajes de una pieza, están sometidos genera el mecanismo dualista de la exclusión producto del "conjunto de técnicas y de instituciones que se atribuyen como tarea medir, controlar y corregir a los anormales". ${ }^{247}$

Teniendo presente lo expuesto, Foucault identifica en el modelo del panóptico de Bentham una manera de definir las relaciones del poder con la vida cotidiana de los hombres; es el mecanismo de inducir en el individuo un estado consciente y permanente de visibilidad que garantiza el funcionamiento automático del poder y hacer que la vigilancia sea permanente en sus efectos, incluso si es discontinua en su acción. En sí, el panóptico es un aparato arquitectónico diseñado para optimizar la vigilancia en las cárceles: en una edificación circular se coloca en el centro una torre desde donde quien vigila puede ver y a su vez no ser visto

\footnotetext{
${ }^{246}$ Ibid., p. 189.

${ }^{247}$ Ibid., p. 203.
} 
mientras vigila; así, es capaz de crear y de sostener una relación de poder independiente de aquel que lo ejerce; en suma, que los detenidos se hallen insertos en una situación de poder de la que ellos mismos son los portadores. De esto resulta que poco importa, por consiguiente, quién ejerce el poder, pues un individuo cualquiera, tomado casi al azar, puede hacer funcionar la máquina. ${ }^{248}$ El reflejo estético de esta dinámica se verá en la pieza, pues una de sus formas de operar exhibe un sistema de relaciones que pueden ir de arriba abajo, y que en cualquier momento se puede invertir de abajo a arriba o lateralmente; evidenciando así el ejercicio del poder que se apalanca de un personaje sobre otro: vigilantes perpetuamente vigilados. En consecuencia, el poder produce realidad, concluirá Foucault: "El individuo es sin duda el átomo ficticio de una representación 'ideológica' de la sociedad; pero es también una realidad fabricada por esa tecnología específica de poder que se llama la 'disciplina'. [...] De hecho, el poder produce; produce realidad; produce ámbitos de objetos y rituales de verdad. El individuo y el conocimiento que de él se puede obtener corresponden a esta producción". 249

Resulta interesante ver cómo focalizar el control en los engranajes, en la coerción y la procura de una docilidad permanente, en la minucia de los reglamentos, en las normas, en las inspecciones y en las sujeciones a control de las menores partículas de la vida hay un particular interés en los detalles, en una anatomía política del detalle, que coincide con el surgimiento de la pieza y su foco sobre los conflictos de la vida cotidiana. En el detalle se instalan "todas las meticulosidades de la educación cristiana, de la pedagogía escolar o militar, de todas las formas finalmente de encarnamiento de la conducta". ${ }^{250}$ Mientras se dejaban de cantar las grandes

\footnotetext{
248 Ibid., pp. 203-205.

249 Ibid.. p. 198.

${ }^{250}$ Ibid., p. 143. En la misma página, señala Foucault: "Y una Historia del Detalle en el siglo XVIII, colocada bajo el signo de Juan Bautista de La Salle, rozando a Leibniz y a Buffon, pasando por Federico II, atravesando la pedagogía, la medicina, la táctica militar y la economía, debería conducir al hombre que había soñado, a fines del siglo, ser un nuevo Newton, no ya el de las inmensidades del cielo o de las masas planetarias, sino de los "pequeños cuerpos", de los pequeños movimientos, de las pequeñas acciones".
} 
hazañas y mientras la iconografía pictórica y escultórica de las elites dejaba de ser un asunto público para trasladarse a espacios más privados, la representación de la vida cotidiana se masificaba, mostrando al hombre común con todas su precarias cualidades y sus despojos naturales. El poder, como lo señala Foucault, no sólo se hacía invisible en sus mecanismos sino, también, en la estética que la caracterizaba. Si la observación minuciosa del detalle y su consideración política como mecanismo de control se volvió relevante para el poder, hombres como Ibsen, Strindberg o Chejov vieron o sintieron que con todo el conjunto de técnicas operadas por las disciplinas, todo su corpus de procedimientos y de saber, de descripciones, de recetas y de datos, nacía el hombre del humanismo moderno Y éste, según Foucault, garantiza el mantenimiento de la organización social:

Entiendo por humanismo el conjunto de discursos mediante los cuales se le dice al hombre occidental: «si bien tú no ejerces el poder, puedes sin embargo ser soberano. Aún más: cuanto más renuncies a ejercer el poder y cuanto más sometido estés a lo que se te impone, más serás soberano». El humanismo es lo que ha inventado paso a paso estas soberanías sometidas que son: el alma (soberana sobre el cuerpo, sometida a Dios), la conciencia (soberana en el orden del juicio, sometida al orden de la verdad), el individuo (soberano titular de sus derechos, sometido a las leyes de la naturaleza o a las reglas de la sociedad), la libertad fundamental (interiormente soberana, exteriormente consentidora y «adaptada a su destino»). En suma, el humanismo es todo aquello a través de lo cual se ha obstruido el deseo de poder en Occidente -prohibido querer el poder, excluida la posibilidad de tomarlo- ${ }^{251}$

Con Foucault hemos querido sustentar que en el centro de la pieza se encuentra el hombre del humanismo moderno, un sujeto moral que creería alcanzar su nivel más alto después de la ilustración y que al final sólo ha descubierto que los hombres somos el infierno de los otros hombres en tanto somos el infierno de nosotros mismos. Pero con Foucault estamos ante una mirada general, a pesar de su perspectiva sobre los detalles, que podríamos denominar el macrocontexto de la pieza, mientras que con Goffman hemos tratado de introducir la operación de ese macrocontexto en los individuos y en su relación con sus semejantes, en los momentos

${ }^{251}$ Michel Foucault, Más allá del Bien y del Mal (1975), en Microfísica del poder, trad. Julia Varela y Fernando Alvarez-Uría, Las Ediciones de La Piqueta, Madrid, 1992, p. 36-37. 
en que interactúan y donde conocemos los conflictos que los atraviesan en específico, en lo que podríamos llamar el microcontexto de la pieza. Si entendemos que somos individuos operadores de la maquinaria del poder con la cual vigilamos a los otros y nos vigilamos a nosotros mismos, entendemos que, en el examen de tal realidad mediada, Agustín tiene razones para humillar y humillarse, Celia condena el parasitismo de su tío pero se condena a sí misma con la presión a la que se somete, Mario se impone una visión de la felicidad y se la impone a los otros, las Santoveña tratan de no caer en lo que juzgan en las demás personas del pueblo, especialmente a las de sexo femenino.

Con Goffman hemos señalado sobre la importancia de la situación inicial, del despliegue informativo entre los personajes y la evaluación de tal información. Sin embargo, a ese encuentro no llegamos en blanco, pues el macrocontexto que hemos señalado con Foucault nos provee de ciertos elementos que nos permiten crear un puente de acercamiento al otro. Para Goffman estos elementos se pueden dividir según estamos familiarizados o no con el otro. Si no se conoce al otro, el individuo puede recoger señas de su conducta y aspectos que le permitan aplicar su experiencia previa con individuos aproximadamente similares al que tienen delante o aplicarle estereotipos; por experiencias anteriores, puede suponer que es probable encontrar sólo individuos de una clase determinada en un marco social dado; puede confiar en lo que el otro dice de sí mismo o en las pruebas documentales que él proporciona acerca de quién o qué es. Si tiene una relación familiar o previa con el otro utilizará las experiencias previas para confiar o no en suposiciones sobre la persistencia y generalidad de rasgos psicológicos como medio para predecir su conducta presente y futura. ${ }^{252}$

Activada la interacción, los participantes cooperan, según Goffman, por una sola definición total de la situación que "implica no tanto un acuerdo real respecto de lo que existe,

${ }^{252}$ Goffman, op. cit. p. 13. 
sino más bien un acuerdo real sobre cuáles serán las demandas temporariamente aceptadas (las demandas de quiénes, y concernientes a qué problemas). También existirá un verdadero acuerdo en lo referente a la conveniencia de evitar un conflicto manifiesto de definiciones de la situación". ${ }^{253}$ Si la disciplina panóptica está aceitada para mantener la paz del Estado y prevenir los actos de sedición, su operación también se hace presente en las interacciones de los individuos quienes procuran llegar a acuerdos que permitan mantener la integridad de la situación en orden, su statu quo. La tranquilidad dada por la definición de la situación proyectada por los individuos, agrega Goffman, proporciona un plan para la actividad cooperativa subsiguiente, de lo que se destaca que dicha proyección tiene también un carácter moral particular, en "que todo individuo que posee ciertas características sociales tiene un derecho moral a esperar que otros lo valoren y lo traten de un modo apropiado". ${ }^{254}$

Quizá la obra en la que más se refleja que la situación proyectada por los diferentes participantes armonizan suficientemente entre sí como para que no se produzca una abierta contradicción es Fotografía en la playa ${ }^{255}$ de Emilio Carballido. No porque no haya conflictos, sino porque éstos no se dan en relación estrecha entre los dieciséis personajes, sin contar al fotógrafo, que presenta la obra; la tensión que genera, básicamente, se encuentra en la reunión familiar en la que cada integrante tiene sus propias demandas morales para ser tratados y que algunos, para evitar el conflicto, complacen. Fotografía en la playa tiene la característica de presentarse en el momento previo a la toma de una foto en la que casi todos los descendientes de la abuela, la madre de Celia, aparecerán: "Una vez más, mientras lo permita el destino, toda la familia está reunida. Bueno, faltan algunos nietos, y hay aquí gentes que no nos tocan de nada, pero vamos a quedar unidos en un retrato. Qué hermoso es eso", manifiesta Celia. La

\footnotetext{
253 Ibid., p. 21.

${ }^{254}$ Ibid., pp. 24-25.

${ }^{255}$ Emilio Carballido, Fotografía en la playa, Editores Mexicanos Unidos, México, 1985, pp. 166-240.
} 
antesala de la toma de la foto es pretexto para que Carballido muestre las peripecias que ha vivido cada uno de los hijos de Celia y de la perspectiva que su prole tiene del mundo.

El cuadro está representado principalmente por la Abuela, madre de Celia, quien está feliz de tener a todos sus hijos varones en casa, a los que está tratando de complacer para hacerles la estadía lo más agradable posible. Su hijo Adrián salió hace poco de la cárcel, donde pagó una condena por un desfalco que cometió con el fin de mantener el estatus familiar y el estilo de vida de su esposa; como aderezo, Adrián defiende el comportamiento de su esposa a pesar de que nunca lo visitó mientras estuvo en la cárcel porque a ella no le parecía digno de su estatus social. Por otra parte, su hijo Agustín es el que está mejor acomodado económicamente, su esposa, Veva, ha engordado desde que tuvieron un bajón económico y dejó de alimentarse bien para cuidar a su esposo y a sus cinco hijos; además, gracias a su gestión, Agustín pudo conseguir el puesto que les permite vivir holgadamente. Héctor, por su parte, es un intelectual que constantemente está reflexionando sobre la vida y que vive en la capital, en donde puede ejercer su homosexualidad abiertamente. Y Constanza es su única hija mujer, quien se ha visto obligada a quedarse a cuidar a su abuela y a su madre; la que se desacomoda con la presencia de los varones en la casa materna; la que renunció a un hombre porque quería trabajar y ser independiente; la que paga las cuentas de la casa, y la que sueña con irse con un mecánico que le ha propuesto viajar a Oaxaca.

A pesar del número de personajes, Fotografía en la playa alcanza a hacer una exhibición de los estados emocionales de los personajes del cuadro principal, especialmente por la combinación de tonos cómicos y serios que plantea Carballido. Como se señaló antes, los conflictos no se dan a una gran escala entre los personajes, los acuerdos de la situación inicial se mantienen mientras los escuchamos hacer una reflexión y una retrospección sobre sus vidas. Sin embargo, Constanza, con la poca fuerza de dignidad que le queda, sí se alza en contra de los 
acuerdos dentro de su establecimiento familiar. A Agustín le reclama porque envía un dinero totalmente simbólico para el mantenimiento de su abuela y su madre; a Héctor y Adrián les pide que contemplen la posibilidad de ir a vivir a la casa materna, para que ella así pueda darse un aire para sí misma, para que quizá pueda acompañar a su amante a Oaxaca:

CONSTANZA: Si me hubiera yo casado a tiempo... iba yo a casarme, se han de acordar, ¿verdad? Iba yo a casarme. Estaba... de la edad de Vevita. Pero él tenia un carácter... él era de esos de tenerme en la casa, "mi mujer no trabaja, la mantengo yo", él era... Yo quería ser independiente. (Se ríe.) Independiente. Por eso no me casé. (Se para enfrente de los tres.) No puede ser. Voy a ser una vieja. Se me ha ido la vida en cuidar a mama y a la mima. No puede ser! También yo tengo que... También yo quiero... Héctor: tú siempre has hecho tu santa voluntad, desde chico; tú has hecho todo lo que has querido. Y eres libre. Nada mas das tus clases y haces tus libros... Pues acá puedes dar tus clases! Si hasta te pagarían mejor que en México.

HÉCTOR: Eso crees.

$[\ldots]$

AGUSTÍN: Y tengo cinco hijos, responsabilidades, y la exigencia de una vida social, y nadie me da gastos de representación, pero no tengo que hacerlos, y tengo que viajar...

CONSTANZA: ¡Y yo no tengo nada! ¡Nada! Responsabilidades. Ninguna vida social. Y pago todo lo de la casa, hasta los impuestos.

ADRIÁN: No te pongas así.

CONSTANZA: ¿Y cómo quieres que me ponga? Se largaron los tres, hicieron sus tres vidas y lograron dejarme aquí enganchada, los tres.

HÉCTOR: Lo dices como si hubiera sido de intento.

CONSTANZA: Fue un intento. Fue un intento. Fue un intento. Cada pasito que vamos dando es de intento, conduce a donde queramos. Fue un intento. Me dejaron aquí. (Se sienta en la silla.)

Aunque la escena tiene un tono climático, no es el clímax de la obra. Para el clímax, Carballido ha planteado un momento alucinante: al primer conteo del fotógrafo, los personajes revelarán sentimientos, emociones, deseos ocultos; al segundo, momento del fogonazo de la cámara, hablarán como si ya estuvieran muertos recordando el momento en que murieron o su velorio. Quizá el parlamento final cierra la forma total de pieza de Fotografía en la playa, con una Constanza mirando mucho tiempo después la fotografía tomada y diciendo: "Las dos solas aquí en la casa. Viendo esta foto, contando los difuntos. Las dos quedamos todavía, la abuela y yo. Pero la foto ha ido borrándose, poco a poco". Que Constanza diga que aún cuida a la abuela cuando muchos ya han muerto sólo significa que nada de lo que tenía propuesto hacer lo hizo: 
no pudo cambiar la trayectoria de vida que traía y tampoco logró cambiar, aunque sea, la trayectoria propia de sus hermanos, ${ }^{256}$ lo que significa el nivel de respeto u opresión que sentía ante la situación y el rol dentro de su familia.

Pero si en Fotografía en la playa el acatamiento a la situación pactada con la familia por parte de Constanza es casi total, al personaje de Tacha, en De pétalos perennes, de Luis Zapata, ${ }^{257}$ le bastarán tan sólo un par de comentarios sobre la decencia a su patrona para sentir todo el castigo por romper las reglas que existían entre las dos. Para Goffman, una regla de conducta puede ser definida como una guía para la acción, recomendada, no porque sea agradable sino porque es adecuada o justa; además, impactan sobre el individuo de dos formas generales: "Directa, como las obligaciones, que establecen cómo está moralmente obligado a conducirse; indirecta, como expectativas, que establecen cómo otros están moralmente obligados a actuar en relación con él”. ${ }^{258}$ Sin embargo, Adela, la patrona de Tacha, constantemente le está cambiando las reglas, llevándola a una constante indefinición de la situación que no le permite tener expectativas estables de parte del trato de su jefa hacia ella, pero reforzando la obligación de su comportamiento sumiso hacia Adela. La anécdota de De pétalos perennes puede llegar a ser bastante simple: Adela, mujer adinerada, solitaria y con todo el tiempo del mundo se hace acompañar de Tacha para paliar tales necesidades; así, lo que empieza como un juego en el que Adela se ofrece como guía para que Tacha se dirija de la

\footnotetext{
${ }^{256}$ Hay una conversación entre Celia y Héctor que se da en los siguientes términos y que revelan la ignorancia que tiene Celia de la situación de su hija: "CELIA: Hijo, yo sólo soy feliz cuando ustedes están conmigo, ¿dices mudarte vivir acá? / HÉCTOR: Se me ocurrió. / CELIA: Hijo mío llevas una vida muy libre... no se como te sintieras volviendo a este lugar tan chico donde todo mundo nos conoce. / HÉCTOR: Yo me sentiría bien, el lugar, quién sabe. Y Constanza podría tomarse unas vacaciones largas, descansar de la casa, de su trabajo, de tantas responsabilidades. Bien lo merece. / CELIA: Hijo mío, Constanza nació para vivir así, con nosotros. Obsérvala, siempre está feliz". Ibid., p. 235.

${ }^{257}$ Luis Zapata, De pétalos perennes, manuscrito donado en 1988 a la Biblioteca de las Artes, del Centro Nacional de las Artes.

${ }^{258}$ Erving Goffman, Ritual de la interacción, trad. Floreal Mazia, Editorial Tiempo Contemporáneo, Buenos Aíres, 1970, p. 49-50.
} 
mejor manera a los hombres que escriben ofreciendo su amistad en las secciones sentimentales de las revistas femeninas, termina en riña y ejercicio de poder cuando Adela decide llevarse a cada hombre que la contacta a los hoteles de la ciudad; el resultado de la concupiscencia de Adela, es que preferirá continuar siendo infiel a su marido y disfrutando de la juventud de sus remitentes, lo que la lleva a despedir a Tacha para que esta información no sea revelada.

Adela usa sobre Tacha una forma bastante sofisticada de dominació. Establecida la relación ama-sirvienta, Adela ofrece a su empleada una amistad que, se supone, suaviza la relación de jerarquía:

A: Porque si no le escribes tú, le escribo yo; digo, de tu parte.

T: Ay, no, señora, a mí no...

A: Bueno, no de tu parte; le escribo yo y me pongo un seudónimo.

T: ¿Un qué?

A: Un nombre falso. Nada más para divertirnos. (Pausa) Ay, a veces me aburro tanto...

$\mathrm{T}:$ ¿Usted, señora?

A: Sí, yo, ¿Qué tiene? ¿Es que las mujeres ricas no tenemos derecho a aburrirnos?

T: No sé. Si yo fuera rica no me aburriría.

A: ¿Por qué?

T: Pues siempre tendría algo que hacer. $\mathrm{O}$ aunque no tuviera nada qué hacer, me gustaría poder estar tirada todo el tiempo, nomás viendo revistas, así como estamos ahorita.

Después de las obligaciones diarias o, incluso, haciéndolas a un lado por su propio mandato, Adela necesita a Tacha para reafirmar su existencia: revisan las revistas femeninas, hablan de los sueños aspiracionales de Tacha y de las equivalentes esplendorosas añoranzas de Adela, le otorga confianza para que se dirija a ella como "Adela" y no como "señora Adela", le pide que le diga si está bella, le brinda consejos para cuando sea una señora como ella, etc. Tacha, hasta donde puede, trata de mantenerse en el lugar correcto de su comportamiento, pero un ejemplo de la manipulación de Adela se ve en los constantes cambios que le impone a su sirvienta del uso de los vocativos. Goffman señala que "los saludos proporcionan una manera de mostrar que una relación sigue siendo lo que era al terminar la coparticipación anterior, y por lo general esta relación implica una suficiente supresión de hostilidades como para que los 
participantes bajen temporariamente [sic.] la guardia y hablen". ${ }^{259} \mathrm{Si}$ equiparamos los saludos y los vocativos, Adela siempre determina de esa manera cómo se siente con respecto a Tacha. Cuando está de buen humor pide que la tuteen, pero si su temperamento cambia intempestivamente, la hostilidad hace su aparición y Tacha no sabe en qué momento la relación se quebró y dejó de ser de confianza. En consecuencia, la imagen de sí misma de Tacha está en constante reacomodamiento, si coincidimos con Goffman cuando afirma que "el individuo involucrado en el mantenimiento de una regla tiende también a comprometerse con una imagen particular de sí mismo". ${ }^{260}$ Como Adela constantemente está poniendo en zona de infracción de la regla a Tacha o exaltando su compañía, la desacredita automáticamente por no cumplir las expectativas que la regla impone, ya sea como sirvienta o como "amiga". Para Goffman, las reglas de conducta convierten la acción o la inacción en expresiones que comunican significados del que sigue o no las reglas, representan una forma de confirmación del yo.

En la clasificación de las reglas vuelven a coincidir Goffman y Foucault. Recordemos que, para el francés, el castigo en un régimen disciplinario supone una doble referencia jurídiconatural: por un lado un "orden artificial", dispuesto de manera explícita por una ley, un programa, un reglamento. Tal idea es concebida por Goffman en términos de regla sustantiva, la cual "orienta la conducta en relación con asuntos acerca de los cuales se siente que tiene importancia por derecho propio, aparte de lo que la infracción o el mantenimiento de la regla expresa sobre el yo de las personas involucradas". ${ }^{261}$ Así, el código que gobierna las reglas sustantivas abarca la legislación, la moral, la ética. La otra referencia para el castigo en la disciplina, según Foucault, es un orden definido por unos procesos naturales y observables. Análogamente, Goffman habla de la regla ceremonial, la cual "orienta la conducta en asuntos

\footnotetext{
${ }^{259}$ Ibid., p. 43.

${ }^{260}$ Ibid., p. 51.

${ }^{261}$ Ibid., p. 53.
} 
respecto de los cuales se siente que tienen una significación secundaria, o inclusive ninguna, por derecho propio, y que su importancia principal es la de un meollo convencionalizado de comunicación por el cual el individuo expresa su carácter o transmite su apreciación de los demás participantes en la situación". ${ }^{262}$ El código que gobierna estas reglas se puede incorporar a lo que se llama etiqueta y las formalidades. En De pétalos perennes, Adela plantea una situación asimétrica a Tacha, entendido esto como la manera en que unos tratan a otros de distinta manera a como son tratados. Así, la lleva de un trato simétrico, en el que la iguala, al trato asimétrico de la jerarquía existente entre amo-empleado. La situación se mantendrá hasta el final cuando Tacha es despedida porque destapa sus valores e insiste a su patrona que verse con hombres que no son su esposo en hoteles no es de mujeres decentes. Cuando Tacha se arrepiente de su postura, Adela la ha obligado a pedir perdón, y cuando ésta -victimizada- se lo acepta, Tacha se va despedida de su trabajo, pero antes, la patrona le subraya que le hubiera dolido que se fuera sin que la empleada le reconociera la bondad de aceptarle el perdón.

Las dinámicas del poder en la vida cotidiana tienen mecanismos tan sutiles como los expuestos con Adela y Tacha, especialmente en su forma de hacer cargar sobre el oprimido los mecanismos de su propia opresión. Sin embargo, como destaca Miller, el hombre común alcanza estatura trágica -entendida está, quizá, como forma de cierta nobleza-, cuando intenta, por lo menos, levantarse contra aquellas circunstancias que lo oprimen. La pieza también vendría a mostrar cómo, en su humanismo moderno, el hombre común, creyéndose libre, no se levanta contra su macrocontexto, sino contra su representante en el microcontexto, pretende "matar al mensajero", pero en franco conocimiento del fracaso desde que lo intenta. Esos intentos de levantamiento los entendemos como levantamientos contra la definición de las situaciones acordadas, levantamientos contra aquello que define lo que es o quien se es en

${ }^{262}$ Ibid., p. 54. 
marcada situación de desventaja. A esos momentos en que quebramos el yo con que nos hemos generalizados ante los otros, Goffman le llama disrupciones.

Hemos de suponer que en el momento cero de una pieza los personajes han acentuado los acuerdos y minimizado las oposiciones. Reconocer esta fórmula es reconocer que de manera subyacente siempre hay grados de insatisfacción ante la definición de la situación. Así, cuando la pieza arranca como tal, las oposiciones aparecen y crecen hasta maximizarse de manera inversamente proporcional a la de los acuerdos acentuados, que pierden su efecto controlador. A las circunstancias que llevan a que se contradice o se desacredite la definición de la situación, Goffman las llama disrupciones. Así, "las disrupciones de la actuación repercuten en tres niveles de abstracción: la personalidad, la interacción y la estructura social". ${ }^{263}$

Sobre los efectos de las disrupciones en la interacción social, la situación cesa de estar definida, las posiciones previas se vuelven insostenibles, y los participantes se encuentran sin un curso de acción claramente trazado, llegando a molestar, confundir o desconcertar a los participantes: "En otras palabras, se desorganiza el pequeño sistema social creado y sustentado por la interacción ordenada y metódica". ${ }^{264}$ Quizá el ejemplo más acorde a este tipo de disrupción, es el que sucede en Los frutos caídos. En los momentos previos al inicio de la obra, Celia está en su trabajo, en su casa, con sus hijos, su esposo y aceptando las galanterías de Francisco, joven que después la seguirá hasta la casa de su padre. Por su parte, Fernando y familia viven con una economía difícil, soportando a la tía Paloma, pero tranquilos porque Celia lleva diez años sin presentarse ni reclamarles la propiedad de la casa. Cuando Celia llega, la situación se vuelve desconcertante, porque no está segura de por qué está allí, y su tío entra en una incertidumbre que lo vuelve más agresivo de lo normal.

\footnotetext{
${ }^{263}$ Goffman, La presentación de la persona en la vida cotidiana, op. cit., p. 259.

${ }^{264}$ Ibid., p. 258.
} 
Las consecuencias que pueden tener las disrupciones desde el punto de vista de la estructura social tienen que ver con unidades sociales más amplias -equipos, establecimientos sociales, etc.- que "se ven comprometidas cada vez que el individuo representa su rutina; en cada actuación tiende a ser sometida a prueba su legitimidad y puesta en juego su reputación permanente". ${ }^{265}$ Obras como De pétalos perennes y Con la frente en el polvo representan este tipo de disrupciones. Por un lado, Tacha tiene que estar constantemente respondiendo a los estados de ánimo de su patrona, lo que siempre la coloca contra la pared en su trabajo como empleada del servicio de una familia adinerada. Por su parte, Agustín, ante la incapacidad de perdonar a su madre, debe ceder la confesión de ésta a un cura subalterno; la consecuencia para ese cura, ante la evidencia de la imagen rota del obispo, es que es confinado a una iglesia lejos de Agustín.

Por último, las consecuencias que pueden tener las disrupciones desde el punto de vista de la personalidad individual tienen que ver con que el individuo "puede comprometer profundamente su yo, no sólo en su identificación con un papel, un establecimiento y un grupo determinados, sino también en la imagen de sí mismo como alguien que no desorganiza la interacción social ni traiciona a las unidades sociales que dependen de esa interacción". ${ }^{266}$ Con este tipo de disrupción, el individuo puede llegar a desacreditar las imágenes que tiene de sí mismo en torno de las cuales se forjó su personalidad. Las jóvenes Santoveña, de Señoritas a disgusto, pueden ser ejemplo de tal circunstancia. Como se describió, las consecuencias para Luisa y María de saberse infelices, a causa de los parámetros de vida que se habían formado, son devastadoras.

\footnotetext{
265 Ibid., pp. 258-59.

${ }^{266}$ Ibid., p. 259.
} 
Por otro lado, Goffman resalta que, después de las disrupciones, el grupo en el que el individuo interactúa suele reacomodarse en favor del individuo para volver a equilibrar la definición de la situación:

A veces se producen disrupciones a través de gestos impensados, pasos en falso y escenas, con lo cual se desacredita o contradice la definición de la situación que se quiere mantener. La mitología del equipo hará frente a estos hechos disruptivos. Los actuantes, el auditorio y los extraños aplican técnicas para salvaguardar la representación, ya sea tratando de evitar probables disrupciones, subsanando las inevitables o posibilitando que otros lo hagan. Para asegurar el empleo de estas técnicas, el equipo tenderá a elegir miembros leales, disciplinados y circunspectos, y un auditorio que se comporte con tacto. ${ }^{267}$

La puerta, ${ }^{268}$ de Edgar Ceballos, acredita este tipo de mecanismo en que, ante varios pasos en falso del personaje del cliente, la maestra lo reacomoda y lo vuelve a traer a una definición de situación más tranquila. La historia transcurre a la hora de cerrada del bar de la maestra. El hombre, en la tercer edad, ha llegado con un celular en la mano y quiere que se le atienda cuando la maestra, una mujer en sus cincuenta, se disponía a regresar a su casa. El cliente quiere hablar con alguien porque supuestamente discutió con su novia y al encontrar el lugar de la maestra abierta, ve la posibilidad de entablar contacto con ella:

CLIENTE: La edad no es un obstáculo par hacer cualquier cosa...

MAESTRA: ¿Como coquetear, por ejemplo? Creo que, en realidad, quien se quiere pasar de listo es usted.

CLIENTE: ¿A caso la he ofendido?

MAESTRA: No, y si intenta hacerlo, me tiene sin cuidado. A diario escucho proposiciones como la suya. Seis un ocho veces al día como promedio. Y más si me ven sola.

CLIENTE: ¿A mi edad tengo el tipo de don Juan o qué cosa? No tiene por qué decirme eso.

MAESTRA: Lo hago porque aparenta ser un viejecito tranquilo y esos son los más peligrosos.

CLIENTE: ¿Y usted qué se cree? Una mujer madura... Y conste que no le digo viejecita... una mujer madura ante la cual necesariamente todos los hombres maduros, en la plenitud de su vida, tenemos que postrarnos a sus pies.

Las conversaciones siguen en ese tono desafiante, se hacen varios recuentos de sus vidas, se revelan secretos, hasta que la maestra decide tomar la mano del cliente y llevarlo hasta la puerta que da a la casa donde supuestamente vivía con su exmarido, al que aún espera.

\footnotetext{
267 Ibid., p. 255.

${ }^{268}$ Edgar Ceballos, La puerta, Escenología, México, 2000, pp. 11-79
} 
Emocionado el cliente de creer que todo el rato de conversación ha dado fruto, se encuentra, al abrir la puerta, con una pared. La situación deja completamente avergonzado al cliente, pero la maestra le invita a ayudarle a cerrar, y, sobre todo, a empezar desde cero su conversación:

CLIENTE: ¿Vamos?

MAESTRA: (Apaga la luz) Se le olvidó algo.

CLIENTE: ¿Qué cosa?

MAESTRA: (Le señala el celular) Su teléfono.

CLIENTE: No sirve. Lo uso sólo para llamar la atención.

MAESTRA: (Toma el teléfono y lo tira al bote de basura) Creo que ya no lo necesitará más. (Lo observa detenidamente) Tampoco ese peluquín; no le queda. (Se lo quita)

CLIENTE: (Titubea un instante) Me cuesta trabajo acostumbrarme a mi edad... No se si sea angustia.

MAESTRA: (Lo interrumpe) ¿Cómo me dijiste que te llamabas? (Salen)

Este momento de salvación suele ser recurrente en la pieza, no porque haya como tal una redención, como lo aparenta La puerta, sino porque opera como el mecanismo que encauza de nuevo al personaje a su contexto, con la salvedad de que ha tocado el momento de conciencia que le hacía falta para asumir la realidad que vive. Planteada así, la disrupción puede ser la gran peripecia de la pieza, pues en el desajuste del individuo, del yo, con respecto a su realidad y la visión que tiene de ésta se encontrarán los conflictos de este género. Por último, Goffman tiene un libro entero dedicado al estigma, el cual puede ser ese gran fantasma detrás de una sociedad disciplinada, cómo se describió con Foucault.

Resulta interesante ver que Goffman, en 1963, antes que Foucault, ya anticipaba que la noción de "ser humano normal" podría tener su origen en el enfoque médico de la humanidad o en la tendencia de las organizaciones burocráticas de gran escala como el estado nacional de tratar a todos los miembros, en ciertos aspectos, como iguales: "Cualquiera que sea su origen, parece suministrar la imaginería básica a través de la cual los legos crean generalmente una concepción de sí mismo". ${ }^{269} \mathrm{El}$ estigma y la vergüenza, señala Goffman hace referencia a un atributo profundamente desacreditador que tiene origen cuando el individuo percibe uno de sus

${ }^{269}$ Ibid., p. 17. 
atributos como una posesión impura de la que fácilmente puede imaginarse exento. ${ }^{270}$ Como se ha advertido, la sociedad establece los medios para categorizar a sus individuos y el complemento de atributos que se perciben como corrientes y naturales en los miembros de cada una de esas categorías. Así:

El medio social establece las categorías de personas que en él se pueden encontrar. El intercambio social rutinario en medios preestablecidos nos permite tratar con «otros» previstos sin necesidad de dedicarles una atención o reflexión especial. Por consiguiente, es probable que al encontrarnos frente a un extraño las primeras apariencias nos permitan prever en qué categoría se halla y cuáles son sus atributos, es decir, su «identidad social» [...] Apoyándonos en estas anticipaciones, las transformamos en expectativas normativas, en demandas rigurosamente presentadas. $^{271}$

La característica, entonces, de la situación vital de un individuo estigmatizado tiene que ver con lo que se suele denominar como "aceptación”: "Las personas que tienen trato con él, no logran brindarle el respeto y la consideración que los aspectos no contaminados de su identidad social habían hecho prever y que él había previsto recibir; se hace eco del rechazo cuando descubre que algunos de sus atributos lo justifican”. Por otro lado, para una persona desacreditable, es decir, que su estigma no es evidente o que quizá aún no existe, el problema no consiste en manejar la tensión que se genera durante los contactos sociales. Consiste en manejar la información que se posee acerca de su deficiencia, exhibirla u ocultarla; expresarla o guardar silencio, etc. ${ }^{272}$ "Sea que interactuemos con extraños o con amigos íntimos, descubriremos que las huellas de la sociedad quedan claramente impresas en estos contactos, poniéndonos, en el lugar que nos corresponde". ${ }^{273}$

\footnotetext{
${ }^{270}$ Erving Goffman, Estigma. La identidad deteriorada, trad. Leonor Guinsberg, Editorial Amorrortu, Buenos Aires, 1986, p. 18.

${ }^{271}$ Ibíd., p. 12.

${ }^{272}$ Ibíd., p. 56.

${ }^{273}$ Ibíd., p. 69.
} 
Las bellas imágenes ${ }^{274}$, de Pablo Salinas, explora la lucha entre el temor al estigma y los deseos de satisfacer placeres carnales. Evelia, una profesora de etiqueta y recato, tiene un pasado que la llevó a la soledad y a construir una imagen de sí misma que cumple con todo lo que ella cree que la sociedad le exige en cuanto recato y buenas costumbres: "Sí, querido, pero insisto; lo más importante es conservar una bella imagen pública... lo que se dirá y se pensará de nosotros", dirá a René, quien llega a Evelia interesado en un anuncio que publicó en el periódico. Sin embargo, que asuma su soledad no le impide ser presa de su propia libido, pero los mecanismo represivos de Evelia están completamente amaestrados para aplacar rotundamente cualquier acto que esté fuera de lugar. Posteriormente, René intentará, poco a poco, seducirla pero procurando que se libere de tantas ataduras formales:

RENÉ: ¿No crees que le das mucha importancia a un acto sexual? No tiene trascendencia. EVELIA: (Entre sollozos) ¿Por qué quiere despojar al mundo de la belleza que le da la ilusión? $[\ldots]$

RENÉ: Te gusta complicarte la existencia: he ahí el gusto por las telecomedias, melodramas baratos.

Cuando Evelia cree sentir libre de ataduras, René revela que hace parte de un servicio de acompañantes y ofrece sus servicios a Evelia, quien nuevamente se ve confrontada con respecto a sí misma, lo que es y lo que quiso haber sido. Las bellas imágenes muestra todo el proceso de Evelia ante sus circunstancias, y comprendemos su dinámica emocional hasta el final, cuando, a pesar de ser presa de una imagen correcta, decide seguir contando con los servicios de René. De hecho, el servicio de René le permite complacer su cuerpo y seguir manteniendo la bella imagen que siempre ha querido transmitir ante los demás, con lo que logra esquivar el estigma. Se evidencia así, nuevamente, la manera como los individuos son portadores de sus propias ataduras. También, si se presta atención, la presencia del estigma ronda en todas las obras que

\footnotetext{
${ }^{274}$ Pablo Salinas, Las bellas imágenes, Obra Citada, México, 1988.
} 
se han analizado, lo cual posiblemente requiera de un estudio más específico. Por ahora podemos destacar que, por lo visto, hay una estrecha relación entre la pieza y los mecanismos con que se ha estigmatizado a la mujer. Ninguna de las obras escapa a esta situación, directa o indirectamente. Por lo que se podría concluir que las dinámicas de poder en la vida cotidiana y su presencia en las esferas del universo femenino han tenido su correlato en el género de la pieza. Por último, también se podría ver en el género de la pieza el correlato de la desazón que causó el fracaso del modernismo, una estética de la manera en que la injerencia del poder no está en las cadenas con que amarra los cuerpos que podrían escapar, sino en la manera en que hizo a los individuos maquinas de ese poder, una estética de su éxito. 


\section{CONCLUSIONES}

Un recorrido histórico lineal sobre los grandes acontecimientos acaecidos a partir del siglo XVIII no son suficientes para tratar de hacer una exposición sobre los orígenes de la pieza y su papel dentro de la teoría de los siete géneros propuesto por Luisa Josefina Hernández. Ha sido necesario abordar la teoría dramática y su subdivisión correspondiente en la teoría de los géneros para poder entender la perspectiva que puede llegar a dar la teoría de los siete géneros. A la luz de las configuraciones que perfila la teoría dramática, se procuró dar una visión de los orígenes de la pieza a nivel de procesos humanos, sociales y estéticos, pero teniendo en cuenta, ya no sólo las narraciones de los hitos históricos sino desde una perspectiva en que las dinámicas de poder construyen realidades e individuos; con lo que se postuló que la pieza es una estética de la manera como opera el poder en la vida cotidiana. Asimismo, se trató de acoger las distintas miradas de varios autores que han teorizado sobre la pieza y sus elementos estructurales para así señalar los puntos de encuentro y de divergencia de cada mirada, con lo cual se espera haber aportado en la discusión sobre la existencia y pertinencia de un género que se concibió como práctica textual teatral desde finales del siglo XIX.

Entender la teoría de los siete géneros y, por ende, el surgimiento de la pieza y la conceptualización dada por Hernández no se puede apartar de la mirada de la teoría dramática, en tanto es necesario comprender la propuesta lejos de una postura inmanentista de la literatura 
en la que los nuevos estilos y los nuevos modos de representar la realidad surgen sólo de una dialéctica al interior de las formas artísticas, aunque se vinculen siempre a formas y estilos del pasado. El drama es un hecho humano: algo que se ve y que es visto; por lo tanto, la reflexión en torno a una obra dramática no se puede apartar de este fenómeno. Por eso se subraya que, así como todo nuevo estilo surge de las relaciones dentro de las formas artísticas junto con la humana necesidad histórico-social de representar la vida, y la relación de esta representación con la impresión de los procesos del devenir social al interior de los creadores, la teoría dramática operará con la misma tendencia entre la creación, las estructuras sociales en las que se enmarca y los análisis que surjan de tal interjección.

Los estudios de teoría dramática conciernen al universo del drama como género literario. Se concentra en las propiedades de la escena y del texto, para estudiar la correlación de los rasgos relativamente invariables en proceso de transformación del drama y de sus subgéneros. El análisis de elementos estructurales que darían unidad a la obra propuesto por cualquier método de teoría dramática puede dar pistas sobre la evolución del drama, de los géneros y de las obras a través de las condiciones de las ideologías imperantes. Sin embargo, se apuesta por una teoría dramática que se alza como hipótesis y no como regla inflexible con la cual acercarse al objeto dramático y poder encontrar así, de entre cientos o miles, una forma de visión posible. La teoría de los siete géneros es uno de esos métodos de acercamiento.

Así, también se resalta que la íntima relación entre estructura e ideología permite plantear la noción de género, cuyo instrumental interpretativo es de suma importancia al dotar de horizontes de expectativas a los lectores y como modelos de escritura para los autores. También es de gran valor para aquellos que están vinculados con el montaje de una obra dramática al utilizarlos como una lengua franca para comunicarse en el proceso de construcción de la puesta en escena. En el ámbito mexicano, la teoría de los siete géneros aporta al sistematizar una 
multitud de criterios de distinción, que, en última instancia, se han forjado a través de los valores ideológicos de una época y de las jerarquías sociales, las cuales infieren en su valoración. Si entendemos que el lenguaje, incluyendo su elaboración artística, está ideológicamente pletórico, como concepción del mundo, entenderemos, entonces, que la existencia de ciertos géneros en una sociedad, así como su ausencia en otra, son reveladoras de esa ideología y nos permiten precisarla con mayor o menor exactitud. De allí que una revisión de la teoría de los siete géneros, como el más divulgado en el teatro mexicano, revele las preocupaciones contemporáneas que les ocupa a los creadores teatrales del país.

La presencia ideológica en los estudios de género permite hacer un rastreo de los orígenes de la pieza. Así, el maestro Usigli, el primer divulgador de la pieza en México, señala que los antecedentes de la pieza se remontan a la segunda mitad del siglo XIX y a autores del continente europeo. Apuntamos que la revolución francesa y el comienzo de la revolución industrial a finales del siglo XVIII generaron transformaciones en Europa, especialmente en los rubros de la economía, la política y la cultura. Hubo un gran impulso demográfico que aumentó la población de las ciudades capitales, así como en los centros industriales y en las escuelas, gracias a que los aparatos de la producción crecían a enorme velocidad. Charles Darwin, Karl Marx, Sigmund Freud y Friedrich Nietzsche renovaron perspectivas sobre concepciones biológicas, religiosas, económicas, la lucha de clases, las mecánicas de la psiquis humanas y la sexualidad, y los conceptos tradicionales de cultura, religión y filosofía occidental. Se vivía una marcha hacia la democracia social y política, mas esto no evitó que se produjeran diversos malestares morales, aunque el empuje de los movimientos económicos era demasiado fuertes como para que aquellas desazones pudieran detenerlos.

Sin embargo, el relato lineal dirigido a través de los hitos históricos más representativos no era suficiente para entender el surgimiento de la pieza, así que con Foucault intentamos dar 
una mirada a este proceso a través de las nuevas dinámicas del poder incorporadas a partir del clasicismo. Con el desorden y la confusión generada por la aglomeración de la población en colegios, fábricas o la milicia, se generaron altos costos para su mantenimiento y control, así como también se necesitó aumentar la rentabilidad de los sistemas productivos. La vigilancia pasó a ser un operador económico decisivo al funcionar como pieza interna en el aparato de producción y como un ejercicio del poder disciplinario. En efecto, ante la necesidad de la burguesía de entregar su capital -representado en materias primas, maquinaria, instrumentosen las manos de la clase popular para que la trabajara, le fue imperante proteger esa riqueza, por lo que la instalación de una moral rigurosa en las clases populares del siglo XIX fue necesaria, misma esta que se instaló al poner en marcha un aparato disciplinario supremamente sofisticado que establecía las relaciones del poder con la vida cotidiana de los hombres: el panóptismo.

Concebido para el sistema carcelario, el panóptico es el mecanismo de inducir en el individuo, a través de una maquinaria disciplinaria, un estado consciente y permanente de visibilidad que garantiza el funcionamiento automático del poder y hacer que la vigilancia sea permanente en sus efectos, incluso si es discontinua en su acción. Tomando modelos del ejército o del hospital con los que se constituyó un saber sobre el cuerpo (control de horarios, formaciones, registro de movimientos, exámenes, etc.) el individuo es vigilado en todos los espacios cerrados en los que transcurre su vida, desde las escuelas hasta la planta de trabajo. En consecuencia, la disciplina panóptica logra conocer y dominar el uso de la fuerza del cuerpo para usarlo como fuerza política que lo maximiza como fuerza útil, aumenta la docilidad y la utilidad de todos los elementos del sistema, logrando que el individuo sea una realidad fabricada por esa tecnología específica de poder, puesto que el poder produce realidad: ámbitos de objetos y rituales de verdad. Así, la bandera publicitaria de las libertades con que se vanagloriaba el siglo de las luces, ocultaban otro invento con un efecto igual de impactante: las disciplinas. A 
través de éstas, los hombres, por medio de normas, reglas, castigos morales más que penales como la vergüenza, el ridículo, la estigmatización-, vigilan a los hombres, quienes viven en un estado de aparente tranquilidad, pero constantemente participan de un juego coercitivo que se activa al instante en que cualquier interacción entre los individuos se pone en marcha.

De esta manera notamos que hay una particular coincidencia, no tan casual, entre el interés por parte del poder de controlar los menores detalles y partículas de la vida y el surgimiento de la pieza y su foco sobre los conflictos de la vida cotidiana. Como diríamos con Foucault, en el detalle se instalan todas las meticulosidades de la educación cristiana, de la pedagogía escolar o militar, de todas las formas finalmente de encarnamiento de la conducta, así como las imposiciones resultantes del sistema productivo contemporáneo. Autores como Ibsen, Strindberg o Chejov lo notaron, por eso sus obras no tardaron en criticar la concepción del hombre moderno que traía consigo este nuevo funcionamiento de sistema social. Ibsen presentó la búsqueda de un individuo con aires liberales, con una férrea crítica a los idealismo, en tanto sus referentes de poder espiritual, económico, social y político; y se vio en la tarea de crear una mitología eficaz acorde a las nuevas ideologías que le dieran al drama un nuevo aliento después de la caída de la tragedia como forma genérica. Strindberg por su lado, llevó a cabo un escrutinio de la psiquis humana, haciendo de lo íntimo algo público al exaltar con tono elevado los sentimientos de sus personajes. Y Chejov retomó de los dos para mostrar que cada hombre, por insignificante que aparente su condición, tiene en sí cargas trágicas que le son propias y que éstas pueden aparecer en los momentos más nimios de su vida. Además, Chéjov vino a dotar al drama de una nueva forma al abandonar la formula del teatro griego donde toda la acción dramática está determinada por la transformación de la situación inicial; el ruso, por su parte, exhibió situaciones desconectadas unas con otras, que en suma revelan la desazón de vidas estancadas. 
Con esto autores se establece el nacimiento de la pieza en donde lo trágico y la tragedia aparecen en las esferas de la vida prosaica, ordinaria y psicológicas. Lo trágico penetra orgánicamente la estructura del drama, pero se encarna en actos y acciones reducidos a marcos familiares y cotidianos que tienen un gran significado fundamental, pues en todas las manifestaciones internas y externas del héroe revela su incompatibilidad respecto a la realidad circundante. También, lo trágico viene a estar en la evaluación que hace el hombre de sí mismo y del desastre que significa que la imagen que hemos elegido para representarnos no está satisfecha con sus circunstancias.

Concluimos entonces, que en la interacción con nuestros semejantes, uno de los dos interactuantes, que puede ser otro individuo o un contexto, define "legítimamente" lo que está sucediendo o lo que alguien es al momento en que definen la situación en que interactuarán. Esto revela que las relaciones de poder existen en la medida en que algunas definiciones de situación son más legítimas que otras, y esa legitimidad es un resultado de quien tiene el poder de proponer y sustentar la definición. Estos momentos van a revelar de cada personaje sus deseos, añoranzas, anhelos y frustraciones y el efecto que tienen estos fenómenos en nuestra relación con los demás. Así, la pieza como género dramático es una estética que exhibe la manera cómo es afectado el sujeto preso de las dinámicas de poder en el contexto cotidiano y la manera cómo reacciona ante ello cuando se le activan sus complejos producto de una sobrevaloración de las añoranzas o los anhelos.

Así, vemos que en el centro de la pieza se encuentra el hombre del humanismo moderno, un sujeto moral que no supo en que momento renunció a la soberanía de su cuerpo para dar paso a unas libertades mediadas por la disciplina panóptica. Para explicarlo, propusimos dos perspectivas que se complementan. El macrocontexto, dado por el funcionamiento en general de las dinámicas de poder en los detalles de la vida cotidiana. Y el microcontexto, el cual está 
afectado por el macrocontexto, y que entendemos como el momento en específico en que los individuos interactúan y revelan sus conflictos particulares.

Para catalogar a este último, nos apoyamos en Goffman y sus estudios sobre la presentación personal en la vida cotidiana. De allí tomamos varios conceptos que permiten ver los alcances de la complejidad de la pieza. Esos conceptos son: la situación inicial, como un acuerdo de las partes para cooperar en la interacción; el despliegue informativo entre los individuos y la evaluación de tal información, con la que los personajes definen sus posturas en el marco de la interacción; las demandas morales: lo que exigen para ser tratados y lo que ofrecen; las reglas de conducta y su injerencia en la construcción del yo; las disrupciones y sus efectos, como aquellos momentos en que el yo por distintas razones se desestabiliza en su relación con el otro; y la recuperación de la definición de la situación, como una vuelta al equilibrio de los acuerdos de la interacción. ${ }^{275}$ Estos conceptos prácticamente definen la trayectoria de los conflictos de los personajes y la trayectoria de los mismos.

También se revisaron los distintos conceptos de los elementos estructurales con que se determinan los géneros dentro de la teoría de los siete géneros dado por distintos autores y vimos cómo determinaban al género de la pieza, los cuales agrupamos en cuatro grandes nociones: Concepción: tema, anécdota y estructura; Relación con la Realidad: enfoque, material, tono; Catarsis: la obra y su relación con el público; Personaje: La vida cotidiana y trayectoria (o dinámica) del personaje.

Concepción: tema, anécdota y estructura: Buscando responder a la pregunta de a qué se refería L.J. Hernández con concepción formal cuando aludía a la pieza, llegamos a la conclusión de que concepción es el criterio con que, dado el posterior análisis de la obra, el autor concibió

\footnotetext{
${ }^{275}$ Es inevitable recordar la tragedia y la manera como el cosmos, ante la revelación del héroe y su posterior destrucción, equilibra de nuevo el orden preestablecido.
} 
la estructuración de la obra. Es una mirada retrospectiva para fijarnos en qué elementos concentró el autor sus energías creativas. En ese caso, la concepción de la pieza es formal porque su forma viene dada por las dinámicas y la estética de la vida cotidiana, la cual impone sus características. Como se señaló con Chejov, la pieza no se ciñe a una situación inicial que determina el drama hacia un fin predeterminado, sino que construye estados anímicos de situaciones en aparente inconexión. Lo anterior determina ya una forma, pero a su vez, multiplica las posibilidades temáticas de la obra, dada su ligazón a la vida cotidiana. Así, la forma se vuelve más dominante que si se concibiera una obra a partir de su temática. De allí también que la anécdota pueda llegar a resultar simple, porque no está dada por grandes acontecimiento sino por las reacciones emotivas del personaje a través de sus conflictos. Por ende, la estructura de la pieza va a mostrar la evolución de las dinámicas del conflicto interior del personaje hacia un clímax en que la intensidad de esas emociones no se pueden controlar, y posteriormente volverá a la normalidad inicial en una constante: no puede hacer mucho para cambiar su realidad. Si lo vemos con la lupa que planteamos con Goffman, la estructura viene a estar dada por la postura del personaje ante sus situación inicial; las fuerzas que lo llevan a levantarse para reducir los acuerdos que tiene con ésta y quien la representa, y evidenciar las oposiciones que antes tenía ocultas; todo esto por un momento que lo llevan a la disrupción del yo que había ofrecido inicialmente; y finalmente él y su grupo de interactuantes encuentran la manera de volver a establecer la situación inicial.

Relación con la Realidad: enfoque, material, tono: En este apartado concluimos que el enfoque determina la relación entre la obra y el género al que se le aplique. En ese sentido, la pieza se alza como un género de enfoque realista porque el material con el que se construye es probable de acuerdo con su relación con la realidad (de causa y efecto, y contemporánea y vigente respecto a parangones de verosimilitud con la realidad del público), puesto que la 
exposición de sus temas y su concepción se esboza como paridad al marco histórico-social, el sistema ideológico imperante y el hombre que vive inmerso en tales marcos. Con respecto al tono, L.J. Hernández no lo refiere como un elemento estructurador directamente. Sin embargo, entenderemos al tono, apoyados en Bajtín y Spang, como las derivaciones y consecuencias físicas y sensoriales de afectos, entendidos éstos en el sentido amplio de estados anímicos que permiten la configuración de una serie de temas y en la particular caracterización de cada forma de expresión. En términos generales, los autores aceptan que la pieza es de tono medio, serio, cotidiano que puede tener ribetes trágicos, cómicos o ambos, todos dados por el ritmo que impone la apenas perceptibilidad del vivir diario.

Catarsis: la obra y su relación con el público: Básicamente la catarsis va a determinar la relación del público con la obra. Un drama buscará generar, entre quienes lo aprecian, que éstos se identifiquen con el héroe para que sentimientos de temor y compasión surjan simultáneamente. Coincidimos con Pavis en que por medio de los personajes y la fábula el espectador se adhiere a los mitos y creencias de su ideología cotidiana. Concluimos también que en el efecto catártico de la pieza el público está expuesto, más que a la compasión, a una autocompasión, a un sentimiento de pena por sí mismo, pues nos impresionamos de que el calificativo y la categoría de "hombre común" se aplica a nosotros mismos y a nuestras propias tribulaciones.

Personaje: La vida cotidiana y trayectoria (o dinámica) del personaje: Suscribimos que para conocer al personaje hay que conocer el contexto que determina su situación pues el personaje no existe independientemente del resto del mundo, además, hablar de situación dramática es hablar de relaciones entre el personaje y su entorno. Además de la perspectiva que dimos con Foucault y Goffman del contexto del personaje, Lizárraga apunta dos perspectivas para entender el contexto del personaje. Por un lado, entender que en la psiquis estamos hechos 
de nuestras añoranzas (ilusiones proyectadas hacia el pasado) y anhelos (ilusiones proyectadas hacia el futuro); que pueden llegar a operar como dos momentos de inadecuada proyección del deseo (ilusión) y como velos que ocultan la frustración (derrota de los propósitos). Los desequilibrios entre nuestras fuerzas vitales y sociales con nuestras ilusiones pueden generar grandes dosis de sufrimiento y por ende marcar nuestras relaciones con nuestros semejantes. Por otra parte, señala que el cotidiano es el estado de "arrojado en un mundo" en el que vive el ser humano, solamente delimitado por el nacimiento y por la muerte: "el ser-ahí". Un mundo preconcebido que se nos impone en forma de una serie de normas sociales, morales, éticas e ideológicas que no dejan accionar al individuo. Esto de por sí trae una derrota: saberse impotente de emprender grandes acciones o conocer de antemano el fracaso al intentar emprenderlas. En la banalidad existencial cotidiana, el "ser-ahí" es acaparado por los otros y se determina en relación a ellos, encontrándose bajo el dominio del otro, desposeído de su propia esencia.

Por otro lado, se tiende a dividir a los personajes entre complejos y simples. El carácter simple es representado por tan sólo unas cuantas facetas del ser humano que son fácilmente definibles ya sea en polos positivos o negativos. Mientras que el personaje complejo se manifiesta a través de los tres canales expresivos del ser humano: la razón, el sentimiento, el instinto, con capacidad para tomar decisiones y de la misma manera con conciencia de sus actos en el pasado o en el presente, positivos o negativos y de las consecuencias que estos traen. En este último se inscribe el personaje de la pieza, quien en la capacidad de tener conciencia de sus actos se encontrará en un punto climático en que llegará a conclusiones sobre su propia vida que antes no había estado en capacidad de percibir. Así, uno de los principales puntos de la pieza es que el personaje, al alcanzar altos niveles de percepción sobre su propia existencia, deriva en la necesidad de reajustar sus propios valores y metas, en lo que sería su toma de conciencia. 
Teniendo en cuenta la exposición hecha de los elementos estructurales que configurarían el género de la pieza, se estudió un corpus de obras a las cuales Virgilio Ariel Rivera consideraba como piezas. Estas fueron: Felicidad y Fotografia en la playa de Emilio Carballido, Los frutos caídos de Luisa Josefina Hernández, Señoritas a disgusto de Antonio González Caballero, Con la frente en el polvo de Luis G. Basurto, De pétalos perennes de Luis Zapata, Las bellas imágenes de Pablo Salinas y La puerta de Edgar Ceballos. En términos generales, las características genéricas se mantienen en cada una de las obras: realistas, tono cotidiano, serios, con aspectos cómicos o trágicos, escenarios cotidianos (casi siempre un pequeño espacio sea un cuarto o una sala), personajes que hacen una valoración de sus vidas, de sus deseos y fracasos, y que se ven en la obligación de asumir las consecuencias de sus actos, formalmente al ritmo de la vida cotidiana.

La exposición de las obras se han tratado de hacer de manera cronológica para percibir también las cuestiones que le interesan a cada uno de los autores según la época y de esa manera encontramos constantes que son propias de la pieza tanto en lo que expone así como la manera cómo se exhibe: los individuos son portadores de sus propias ataduras; la presentación de mecanismos con que se ha estigmatizado a la mujer (lo que, como se anticipó, posiblemente requiera de un estudio más específico) así como definiciones muy precisas y ortodoxas sobre lo femenino y lo masculino; los efectos de la presión que ejerce en los individuos el sistema de producción imperante en que el dinero juega un papel preponderante; conflictos de clases o proyecciones ilusorias sobre el ascenso social; choques entre la concepción de lo moderno y el establecimiento tradicional, o entre lo urbano y lo rural; así como una relevancia sobre castigos morales más que punitivos en los que los personajes son afectados en su yo psíquico más que en su yo físico a través de sanciones jurídicas; un claro funcionamiento binario en las que se definen con fuerza (y arbitrariedad) lo normal contra lo anormal; y un despliegue en las 
estrategias cómo los personajes defienden su integridad producto del constante y estricto examen mutuo. En ese sentido, concluimos que la pieza se podría ver como el correlato de la desazón que ha causado el fracaso de la modernidad y como una estética del éxito de las dinámicas del poder en la vida cotidiana. Así, la pieza viene a demostrar que -en contra de la extendida idea de que en la vida cotidiana sólo hay "cotidianeidad", hechos prosaicos, pocas exaltaciones, poca acción- cada individuo carga con circunstancias que le hacen estar viviendo, a cada momento, su propia aventura; aquello que se denomina como el hombre común es extraordinario en sus desventuras y en sus pequeños triunfos.

Por último, la conclusión más obvia, pero no la menos importante, es la existencia del género de la pieza. Norma Román Calvo señala que la pieza es una denominación del drama europeo de los autores que Usigli admiraba. Para esta autora, "no hay razón particular que sustente la elección del término pieza, que además se presta a confusión al usarse como sinónimo de obra teatral. [...] Deseamos señalar que fue completamente innecesario sustituir el nombre de drama por pieza, porque este rebautizo ha provocado entre los estudios del teatro en México una gran confusión, pues en todo el mundo se reconoce con el nombre de drama y no de pieza". ${ }^{276}$ Sin embargo, aquello de lo que acusa Román Calvo a la denominación de pieza, se puede aludir a su propia conclusión. Drama puede sonar tan genérico como pieza. Sin embargo, lo que estaría en cuestión sería si como práctica textual cabe dentro de los estudios de teoría dramática. Nuestra respuesta es que sí. La denominación pieza, como se ha tratado de demostrar, tiene fuerza en el ámbito mexicano, y su amplio uso es el que al final de cuentas ha sustentado la realización de esta investigación.

\footnotetext{
276 Norma Román Calvo (coord.), Los géneros dramáticos, su trayectoria y su especificad, editado por la Secretaría de Extensión Académica de la Facultad de Filosofía y Letras de la Universidad Autónoma Metropolitana, Ciudad de México, 2007, pp. 130-191.
} 


\section{BIBLIOGRAFÍA}

ALATORRE, Claudia Cecilia, Análisis del Drama, Ediciones Escenología A. C., México D.F. 1999.

ALTHUSSER, Louis, Ideología y aparatos ideológicos de estado (1969), trad. De José Sazbón, en Slavoj Zizek (comp.), Ideología. Un mapa de la cuestión, Fondo de cultura Económica, Buenos Aíres, 2003.

ARISTÓTELES, Poética, trad. del griego Francisco de P. Samaranch, Aguilar, Madrid, 1966.

AUERBACH, Erich, Mimesis, la representación de la realidad en la literatura occidental, Fondo de Cultura Económica, México, 1996.

BAJTIN, Mijail, Estética de la creación verbal, editorial S XXI, México, 1990.

La palabra en la novela, en Problemas literarios y estéticos, Trad. Alfredo Caballero, Editorial Arte y Literatura, La Habana, 1986.

BARTHES, Roland, El efecto de realidad (1968), en Lo verosímil, Editorial Tiempo Contemporáneo, Buenos Aires, 1972.

BASURTO, Luis G., Con la frente en el polvo, en Teatro de Luis G. Basurto, Editores Mexicanos Unidos, México, 1986.

BENJAMIN, Walter, El narrador, en Para una crítica de la violencia y otros ensayos, Taurus, Madrid, 1987.

BENTLEY, Erick, La vida del drama, Editorial Paidos Estudios. Buenos Aíres, 1982.

BORGES, Jorge Luis, La busca de Averroes, en El Aleph, Alianza Editorial, Madrid, 2005.

BOURDIEU Pierre, Campo intelectual y proyecto creador (1966), en Campo de poder, campo intelectual, ed. Montressor, Buenos Aíres, 2002.

CALVO, Norma Román (coord.), Los géneros dramáticos, su trayectoria y su especificad, editado por la Secretaría de Extensión Académica de la Facultad de Filosofía y Letras de la Universidad Autónoma Metropolitana, Ciudad de México, 2007.

Para leer un texto dramático, editorial Pax México, Ciudad de México, 2005.

CARBALLIDO, Emilio, Felicidad, en Tres comedias, Editorial Extemporáneos, México, 1981.

Rosa de dos aromas, Fondo de Cultura Económica, México, 2001, pp. 49-93.

Fotografía en la playa, Editores Mexicanos Unidos, México, 1985.

CEBALLOS, Edgar, La puerta, Escenología, México, 2000. 
CHÉJOV, Anton. Teatro. Editorial Porrua, Ciudad de México, 1989.

DEL RÍO, Marcela, Perfil y muestra del teatro de la revolución mexicana, Fondo de Cultura Económica, México, 1997.

ENGEL, Federico, El origen de la familia, la propiedad privada y el Estado (1884), en:

http://www.marxists.org/espanol/m-e/1880s/origen/cap2.htm.

FOUCAULT, Michel, Disciplina, en Vigilar y castigar, nacimiento de la prisión 1975, trad. Aurelio Garzón del Camino, Siglo XXI Editores, México, 1996.

Entrevista sobre la prisión: El libro y su método (1975), en Microfísica del poder, trad.

Julia Varela y Fernando Alvarez-Uría, Las Ediciones de La Piqueta, Madrid, 1992.

La verdad y las formas jurídicas, Segunda conferencia (1978), Gedisa Editorial, Barcelona, 1996.

Más allá del Bien y del Mal (1975), en Microfísica del poder, trad. Julia Varela y Fernando Alvarez-Uría, Las Ediciones de La Piqueta, Madrid, 1992.

FREUD, Sigmund, Obras completas (Psicopatología de la vida cotidiana, El malestar en la cultura y otros), Editorial Amorrortu, Buenos Aires, 1978.

GARRIDO, Consuelo, No ser héroes, apuntes en torno a la pieza en algunas clases de teoría dramática de Luisa Josefina Hernández, en Claudia Gidi y Jacqueline Bixler (coords.), Las mujeres y la dramaturgia mexicana del sigo XX, ed. El Milagro, México, 2011.

GOFFMAN, Erving, Estigma. La identidad deteriorada, trad. Leonor Guinsberg, Editorial Amorrortu, Buenos Aires, 1986.

La presentación de la persona en la vida cotidiana (1959), trad. Hildegarde B.

Torres y Flora Setaro, Amorrirto Editores, Buenos Aires, 2001.

Ritual de la interacción, trad. Floreal Mazia, Editorial Tiempo Contemporáneo,

Buenos Aíres, 1970.

GASTALDO, Édison, Goffman e as relações de poder na vida cotidiana, Revista Brasileira de

Ciências Sociais, vol. 23, núm. 68, octubre, 2008, pp. 149-153.

GONZÁLEZ Caballero, Antonio, Señoritas a disgusto, libreto del fondo especial de la biblioteca del Centro Nacional de las Artes, 1983.

GONZÁLEZ Mello, Flavio, “El rompecabezas incompleto”, en Estudios Cinematográficos, año 10, núm. 28, México, 2005. 
HERNÁNDEZ, Luisa Josefina, La pieza como género dramático: el jardín de los cerezos, de Chéjov, en Los frutos de Luisa Josefina Hernández, aproximaciones y escritos de teoría dramática, Felipe Reyes Palacios y Edith Negrín editores, UNAM, México, 2011.

INCLÁN, Federico S., Una señorita decente, manuscrito donado en 1988 a la Biblioteca de las Artes, del Centro Nacional de las Artes

JAKOBSON, Roman, "Sobre el realismo artístico", en Teoría de la literatura de los formalistas rusos, Tzvetan Todorov (comp.), Editorial S XXI, México, 2002.

KNOWLES, John Kennet y HERNÁNDEZ, Luisa Josefina, Teoría y práctica del drama, trad. de Antonio Argudín, rev. y pres. de Tomás Espinoza, UNAM, México, 1980.

KUNDERA, Milan, La insoportable levedad del ser, trad. Fernando Valenzuela, Tusquets Editores, México, 2002,

KURGUINIAN, Maria Serguieivna, Hacia una teoría dramática, ed. Toma, México, 2010.

LUKÁCS, Georg, ¿Narrar o describir? (1936), en Carlos Altamirano y Beatriz Sarlo (comps.) Literatura y Sociedad, Centro Editor de América Latina, Buenos Aíres, 1977.

MACGOWAN, Kenneth y MELNITZ, William, Las edades de oro del teatro, Fondo de cultura económica, México, 1992.

MARIO Moncada, Luis, en http://reliquiasideologicas.blogspot.mx/2010/01/i.html

MARTÍNEZ, Fernando. En: Nuestros maestros tomo II. Universidad Autónoma de México, Ciudad de México, 1992.

MILLER, Arthur, Muerte de un viajante, editorial Losada, Buenos Aires, 2004.

$$
\text { La tragedia y el hombre común, en }
$$

http://catedrahumanidadestm.blogspot.com/2009/10/la-tragedia-y-el-hombre-comun.html

MONSIVÁIS, Carlos, Salvador Novo. Lo marginal en el centro, ERA, México, 2004.

NOVO, Salvador, A ocho columnas, Grupo Editorial Gaceta, México.

La culta dama, Grupo Editorial Gaceta, México, 1994.

O'NEILL Eugene, El largo viaje de un día hacia la noche, Editorial Sudamericana Buenos Aires, 1957.

PARTIDA TAYZAN, Armando, Modelos de acción dramáticos aristotélicos y no aristotélicos, Editorial Itaca, Ciudad de México, 2004. 
PAVIS, Patrice. Diccionario del Teatro. Dramaturgia, estética, semiología. Editorial Paidós, Barcelona, 1998

RAMA, Ángel, Indagación de la ideología de la poesía (los dípticos seriados de Versos Sencillos), en Carlo Altamirano y Beatriz Sarlo, Literatura/Sociedad, Hachette, Buenos Aires, 1983, p. 211.

RIVERA, Virgilio Ariel. La composición dramática. Editorial Escenología, México D.F., 2004.

SALINAS, Pablo, Las bellas imágenes, Obra Citada, México, 1988.

SPANG, Kurt, Géneros literarios, Síntesis, Madrid, 1993.

STEINER, George Muerte de la tragedia (1961), Editorial Monte Avila, Caracas, 1991.

TOVAR, Juan. Doble Vista. Editorial El Milagro, 2006.

TODOROV, Tzvetan, El origen de los géneros, en Teoría de los géneros literarios, coord.

Miguel Ángel Garrido Gallardo, Arcos libros, 1988

USIGLI, Rodolfo, Medio Tono, en Teatro Completo de Rodolfo Usigli I, $2^{\circ}$ reimpr. De la $1^{\circ}$ ed. De 1963, Fondo de Cultura Económica, México, 1997.

Discurso por un teatro realista, América, 1937.

Itinerario del autor dramático, 1940.

WILLIAMS, Raymond, El teatro de Ibsen a Brecht, Ediciones Península, Barcelona, 1975.

WRIGHT, Edward A., Para comprender el teatro actual, Fondo de cultura económica, México, 1992.

ZAPATA, Luis, De pétalos perennes, manuscrito donado en 1988 a la Biblioteca de las Artes, del Centro Nacional de las Artes. 


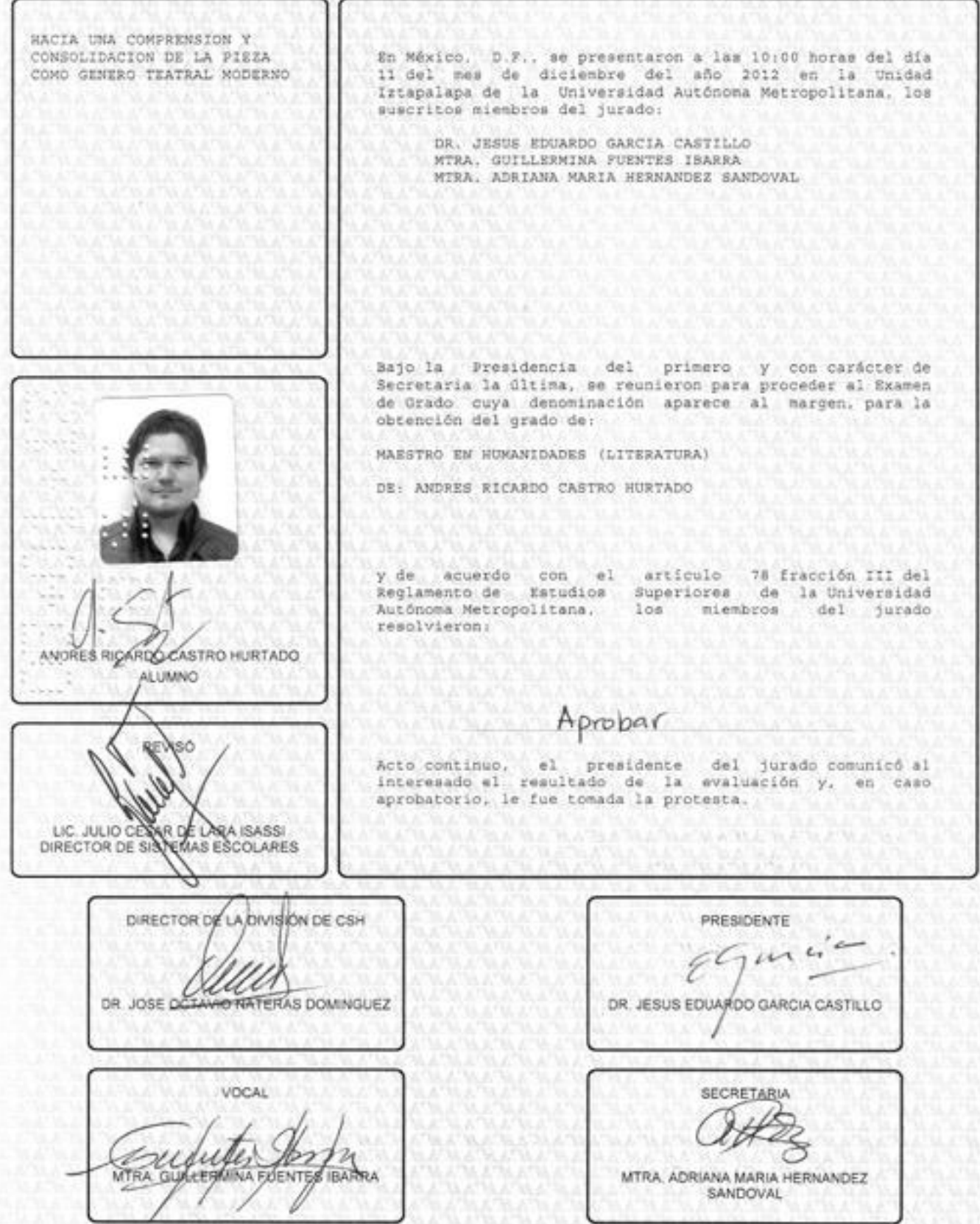

